\title{
A microanatomical and histological study of the scales of the Devonian sarcopterygian Miguashaia bureaui and the evolution of the squamation in coelacanths
}

\author{
Jorge Mondéjar-Fernández (1)*, François J. Meunier (2), Richard \\ Cloutier (3), Gaël Clément (1) and Michel Laurin (1)
}

(1) UMR 7207 (MNHN-Sorbonne Université-CNRS), CR2P, Centre de Recherche en Paléontologie - Paris, Département Origines \& Évolution, Muséum national d’Histoire naturelle, 57 rue Cuvier, CP38, Paris F-75005. [jorge.mondejarfernandez@mnhn.fr], [gael.clement@mnhn.fr], [michel. laurin@mnhn.fr]

(2) FRE BOREA 2030, (MNHN - Sorbonne Université - Univ. Caen Normandie - Univ. Antilles - CNRS - IRD), Département Adaptations du Vivant, Muséum national d'Histoire naturelle, CP26, 43 rue Cuvier, 75231 Paris cedex 05, France. [francois.meunier@mnhn.fr]

(3) Université du Québec à Rimouski, 300 allée des Ursulines, Rimouski, Québec, G5L 3A1, Canada. [richard_cloutier@uqar.ca]

\section{Correspondence}

Jorge Mondéjar-Fernández, UMR 7207 (MNHN-Sorbonne UniversitéCNRS), CR2P, Centre de Recherche en Paléontologie - Paris, Département Origines \& Évolution, Muséum national d’Histoire 
naturelle, 57 rue Cuvier, CP38, Paris F-75005. Email: jorge.mondejar-fernandez@mnhn.fr

Running title: Scales of the early coelacanth Miguashaia 


\section{ABSTRACT}

Coelacanths have traditionally been described as morphologically conservative throughout their long evolutionary history, which that spans more than 400 million years. After an initial burst during the Devonian, a morphological stasis was long thought to have prevailed since the Carboniferous, as shown by the extant Latimeria. New fossil discoveries have challenged this view, with punctual and sometimes unusual departures from the general coelacanth Bauplan. The dermal skeleton is considered to represent one, if not the main, example of morphological stasis in coelacanth evolution and as a consequence, has remained poorly surveyed. The flagrant lack of paleohistological data on the dermoskeleton has resulted in a poor understanding of the early establishment and evolution of the coelacanth squamation. Here we describe the scales of Miguashaia bureaui from the Upper Devonian of Miguasha, Québec (Canada), revealing histological data for a Palaeozoic coelacanth in great detail-and for the first time, and adding to our knowledge on the dermal skeleton of sarcopterygians. Miguashaia displays rounded scales ornamented by tubercules and narrow ridges made of dentine and capped with enamel. At least two generations of superimposed odontodes occur, which is reminiscent of the primitive condition of stem osteichthyans like Andreolepis or Lophosteus, and onychodonts 
like Selenodus. The middle vascular layer is well developed and shows traces of osteonal remodelling. The basal plate consists of a fully mineralized lamellar bone with a repetitive rotation pattern every five layers indicating a twisted plywood-like arrangement of the collagen plies. Comparisons with the extant Latimeria and other extinct taxa show that these features are consistently conserved across coelacanth evolution with only minute changes in certain taxa. The morphological and histological features displayed in the scales of Miguashaia enable us to draw a comprehensive picture of the onset of the coelacanth squamation and to propose and discuss evolutionary scenarios for the coelacanth dermoskeleton.

Keywords: coelacanth, dermoskeleton, histology, odontodes, Palaeozoic, scales 


\section{INTRODUCTION}

Coelacanths (or actinistians) have frequently been described as displaying a remarkable morphological conservatism following an early evolutionary burst at their emergence in the fossil record at the beginning of the Devonian period (around 420 million years ago) (Forey, 1984; Cloutier, 1991a; Zhu et al., 2012). The discovery in 1938 of Latimeria chalumnae (Smith, 1939) off the coast of South Africa was completed by the identification of a second species, L. menadoensis (Erdmann et al., 1998; Pouyaud et al., 1999) from the Sulawesi Island of Indonesia, allowing access to extant material for key morphological comparisons with the relatively rich fossil record of coelacanths (cloutier \& Forey, 1991; Forey, 1998). Genomic data obtained from these extant representatives suggest that there is indeed low molecular diversity within populations of L. chalumnae (Lampert et al., 2012) and low substitution rates in the coelacanth lineage that led to the two extant species (Amemiya et al., 2010, 2013; Lang et al., 2010; Higasa et al., 2012). Molecular data have also revealed the existence of a putative third coelacanth species in Indonesia (Kadarusman et al., 2020). However, the supposed morphological stasis of coelacanths has been challenged by new fossil discoveries (Casane \& Laurenti, 2013) that highlighted important differences in the skull, axial skeleton, and internal organs 
throughout their evolutionary history (Lund \& Lund, 1984, 1985; Forey, 1998; Friedman \& Coates, 2006; Brito et al., 2010; Wendruf \& Wilson, 2012; Cavin et al., 2017; Cupello et al., 2017).

In the case of the dermal skeleton, the alleged conservatism of coelacanths has pervaded anatomical descriptions and led to a flagrant lack of comparative histological information on fossil coelacanth scales, with Forey (1998, p.220) even stating that 'there is little to suggest that they vary in any significant way from the structure seen in Latimeria'. Indeed, the scales of all known extinct and extant actinistians are rounded and are ornamented with tubercles and/or coarse or thin ridges that may break into small leaf- or spoon-shaped tubercles near the anterior margin of the exposed area in early forms. This ornamentation pattern is uniformly maintained in many coelacanths from the Palaeozoic to Recent (e.g. Gavinia, Miguashaia, Diplocercides, Nesides, Rhabdoderma, Whiteia, Piveteauia, Undina, Macropoma, Coelacanthus, Swenzia, and Latimeria) (Stensiö, 1937; Schaeffer, 1941; Forey \& Young, 1985; Cloutier, 1996; Forey, 1998; Forey et al., 2000; Clément, 1999, 2005; Long, 1999) (Table 1)

The histological nature of the ridges and tubercles of the scales and dermal bones of coelacanths remains unclear in many taxa and might lack the seeming homogeneity implied by external observation. In the extant Latimeria, the ridges and 
tubercles have been extensively surveyed and illustrated (Millot \& Anthony, 1958; Millot et al., 1978) and are of odontogenic nature, as they are made of dentine capped with enamel (Bernhauser, 1961; Smith et al., 1972; Castanet et al., 1975; Meunier et al., 2008; Meunier et al., 2019). In extinct forms, the ridges have been reported to be made of dentine in Diplocercides jaeckeli from the Devonian (Gross, 1935, 1966), Undina penicillata from the Jurassic (Gross, 1935, 1966) and Macropoma lewesiensis from the Cretaceous (Williamson, 1849). In Diplurus newarki from the Triassic (Schaeffer, 1952) the scales were tentatively described as being covered by a thin layer of enamel, except on the ridges and tubercles. In the dermal bones of Spermatodus pustulosus from the Permian (Westoll, 1939), the dermal bones display the tubercles are composed of dentine and enamel (i.e., odontodes)-(Meinke, 1982) organized in-displaying several layers (i.e. $\ominus f$ superimposed odontodes) with t-and traces of resorption and redeposition of bone and odontodes, but the scales were not surveyed. Despite this wealth of data and material availability, no comprehensive and comparative histological work has been done on the scales of coelacanths and thus many observations, not properly illustrated by histological preparations, might be considered as unreliable in the absence of a thorough histological survey. Most notably, Gross (1935) already pointed out that the histology of coelacanths had been poorly surveyed and comparative data from Palaeozoic, and 
especially Devonian coelacanths were crucially lacking for comparisons with more recent taxa.

The Devonian fossil record of coelacanths is scarce, represented by taxa such as Eoactinistia foreyi from the Pragian of Australia (Johanson et al., 2006), Euporosteus from the Pragian-Givetian of China (E. yunnanensis) and Germany ( $E$. eifeliensis) (Stensiö, 1937; Zhu et al., 2012), Gavinia syntrips from the Givetian of Australia (Long, 1999), Holopterygius nudus from the Givetian of Germany (Jessen, 1973; Friedman \& Coates, 2006), Diplocercides from the Frasnian of Germany (D. kayseri, D. heiligenstockiensis, D. jaeckeli) and the Visean (Carboniferous) of Scotland ( $D$. davisi) (Stensiö, 1922, 1937; Moy-Thomas, 1937; Jessen, 1966; Forey, 1981), Miguashaia from the Frasnian of Québec (Canada) (M. bureaui) and Latvia (M. grossi) (Schultze, 1973; Cloutier, 1996; Forey et al., 2000), Chagrinia enodis and Coelacanthus welleri from the Famennian of eastern USA (Eastman, 1908; Schaeffer, 1962), and Serenichthys kowiensis from the Famennian of South Africa (Gess \& Coates, 2015). Early coelacanth fossil material is not only rare but also generally poorly preserved, compressed, or simply too precious to allow histological sectioning. Abundantly preserved individuals displaying a good histological quality are even scarcer, dramatically reducing the access to paleohistological data. One of the few exceptions to this limited source of information is the material from Miguasha (Québec, Canada). 
The Miguasha fossil site has yielded exquisitely preserved fossil specimens from a wide range of early vertebrates, including the iconic Eusthenopteron foordi (Jarvik, 1944, 1954, 1980) and Elpistostege watsoni (Westoll, 1938; Cloutier et al., 2020). Miguashaia bureaui (Schultze, 1973; Cloutier, 1991a,b, 1996) represents the only coelacanth found in Miguasha so far. It was a main predator in the estuarine paleoenvironment of the Escuminac Formation (Chevrinais et al., 2017a), which is dated as middle Frasnian in age (Cloutier et al., 1996). The vertebrate specimens from Miguasha are numerous and frequently three-dimensionally preserved, which has given an excellent account of their external morphology (Cloutier et al., 2011, Cloutier, 2013). Likewise, histological features are represented either as hard tissues (e.g. enamel, dentine, cellular bone, cartilage) or as cell spaces (e.g. osteocyte and chondrocyte lacunae), sufficiently well-preserved to allow genome size inference (Thomson, 1972; Organ et al., 2016), as well as soft tissues preservation (Cloutier, 2013). Previous microstructural and histological studies have yielded excellent results on several taxa from the Escuminac Formation, such as the anapsid Euphanerops Iongaevus (Janvier \& Arsenault, 2002; Chevrinais et al., 2018), the osteostracan Escuminaspis laticeps (Janvier et al., 2004), the 'placoderm' Bothriolepis canadensis (Burrow, 2005; Downs \& Donoghue, 2009), the 'acanthodian' Triazeugacanthus affinis (Chevrinais et al., 2017b), the 
sarcopterygians Eusthenopteron foordi (Schultze, 1969; Laurin et al., 2007; Zylberberg et al., 2010; Meunier \& Laurin, 2012) and Scaumenacia curta (Thomson, 1972; Smith et al., 1987), and the actinopterygian Cheirolepis canadensis (Zylberberg et al., 2015; Meunier et al., 2018).

Here, we study the histological morphological, and microanatomical, and histological organization of the scales of the early coelacanth Miguashaia bureaui from the middle Frasnian of eastern Québec (Canada). It constitutes a the first thorough investigation of the dermal scales of a Palaeozoic coelacanth and provides much needed comparative information on the early establishment of the histological features of the actinistian squamation. Comparison with other extinct coelacanths and with the extant Latimeria will provide a more complete picture of the histological diversity in actinistians and better document the evolution of the dermal skeleton in sarcopterygians and early osteichthyans. With these detailed descriptions and holistic approach, we hope to invigorate the study of the paleohistological diversity of the dermal skeleton of actinistians, which has been largely overlooked in most analyses of coelacanth evolution.

\section{MATERIAL AND METHODS}

\section{Material}

\section{Miguashaia}


Original and newly discovered material of Miguashaia bureaui has been studied, focusing on the external morphology of the scales: MHNM 06-41ab, MHNM 06-494 (mean scale diameter: 1.87 $\mathrm{cm}$; total length of specimen: $37.5 \mathrm{~cm})$, MHNM 06-641, MHNM 061232, MHNM 06-1233, MHNM 06-1234, MHNM 06-1236ab, MHNM 061237; MHNM 06-1239; MHNM 06-1318ab; MHNM 06-1633 (mean scale diameter: $0.16 \mathrm{~cm}$; total length of specimen: $6.98 \mathrm{~cm})$, MHNM 06-1809ab (mean scale diameter: $1.28 \mathrm{~cm}$; total length of specimen: ca. $43 \mathrm{~cm}$ ); MHNM 06-2414, ULQ 120ab (holotype). Fossil material used for the histological investigation consists of two separated blocks (MHNM 06-1238; MHNM 06-1495) containing numerous articulated trunk scales. Specimen MHNM 06-1238 (Fig. 1A) displays disarticulated axial and appendicular elements including at least two neural arches (n.ar) and probably haemal spines, caudal fin radials (ra), and a few fine lepidotrichia (lp) most likely belonging to the second dorsal fin. Specimen MHNM 06-1495 (Fig. 1B) shows disarticulated fragments of the opercular series (op.s) and pectoral girdle elements (cleithrum, cl), most of them preserved as imprints of the smooth inner surface of the dermal bones, and some segments of pectoral lepidotrichia (lp) with the characteristic interlocking system. Scales (sc) of specimen MHNM 06-1495 are most likely from the anterior part of the trunk as well as some anteroventral scales. Scales (sc) of specimen MHNM 06-1238 are most likely from the posterior part of the flanks, posteroventral to the second dorsal fin. 
All specimens come from the middle Frasnian Escuminac Formation, Miguasha, Québec, Canada. All the fossil material is housed at the Musée d'Histoire naturelle de Miguasha (MHNM), parc national de Miguasha, Québec (Canada) with the exception of the holotype that is housed at the Université Laval (ULQ), Québec City, Québec (Canada).

\section{Latimeria}

Latimeria chalumnae. The morphology (SEM) and the microstructure (ground sections) of the scales have been examined predominantly from two main specimens: (a) the scales overlying the basis of the pelvic fin of MNHN-ZA-AC-2012-26 (CCC79, adult female, $78 \mathrm{~kg}, 163 \mathrm{~cm} \mathrm{TL}$ ) and (b) several scattered scales of specimen MNHN-ZA-AC-2012-29 (CCC117, adult female, $19 \mathrm{~kg}, 109,5 \mathrm{~cm}$ TL), both captured off the Comoro Islands (Nulens et al. 2011). The scales were fixed in neutral formalin and kept in $70^{\circ}$ ethanol. All specimens are housed at the Muséum national d'Histoire naturelle (MNHN) of Paris (France).

Latimeria menadoensis. Nine scales were sampled from the second known Indonesian extant coelacanth specimen (MZB10003) (CCC 175; adult female 29,2 kg, $124 \mathrm{~cm}$ TL) captured off Manado Tua, Sulawesi Island (Nulens et al, 2011). The scales were originally fixed in formalin, and then stored in $70^{\circ}$ ethanol. After measurements of the odontodes, some scales were studied with SEM and others were used for ground sections. The 
specimen is housed at the Museum Zoologicum Bogoriense (MZB) (Indonesian National Zoological Museum) in Bogor (Indonesia).

Institutional abbreviations: FMNH, Field Museum of Natural History (Chicago, USA); MHNM, Musée d’Histoire naturelle de Miguasha (Miguasha, Canada); MNHN, Muséum national d'Histoire naturelle (Paris, France); MzB, Museum Zoologicum Bogoriense (Bogor, Indonesia); ULQ, Université Laval (Québec City, Canada); YPM, Peabody Museum, Yale University (New Haven, USA) •

\section{Methods}

\section{Miguashaia}

Ground sections were performed on both fossil specimens (MHNM 06-1238 and MHNM 06-1495) at the MNHN. The fossil material was embedded in polyester resin (GBS 1; Brot) and sectioned for study. The various sections were ground and polished to a thickness of 60-80 $\mu \mathrm{m}$ and observed under transmitted natural light with an Olympus BX51 microscope. Pictures were taken with a digital camera Olympus Camedia C-5060 and finalized in Adobe Photoshop.

\section{Latimeria}

For the SEM observations, the scales were steeped in 6 or 12\% sodium hypochloride solution at room temperature (in order to strip the surface of the scales and to destroy the 
unmineralized collagenous fibres, thus cleaning the mineralized front of the basal plate). The scales were then washed in distilled water, dehydrated in absolute ethanol, air-dried, and coated with evaporated gold. The external and internal surfaces of the scales were examined in a JEOL-SEM-35 scanning electron microscope. Thin sections of the scales (30 to $100 \mu \mathrm{m}$ in thickness) were observed in polarized light with a Zeiss Axiovert 35 microscope. Microradiographies were performed on non-decalcified sections (focal point-object distance $10 \mathrm{~cm}$, power 10 to $15 \mathrm{Kv}$ at $7 \mathrm{~mA}$ ). Histological sections after decalcification with EDTA (ethylenediaminetetraacetic acid) and inclusion in paraffin (sections 5 to $10 \mu m$ in thickness) were treated with the following stains: hemalun-picro-indigocarmin, APS, toluidine blue, Prenant's trichrome.

\section{DESCRIPTION}

\section{Morphology}

The external and internal surfaces of the scales match reasonably the previous description by Cloutier (1996) (Fig. 2). All scales of Miguashaia bureaui are almost rounded, slightly broader than long, and both sides of the scales at mid-length are linear and parallel.

The ornamented area (posterior field) occupies approximately two fifths of the area of the scale; it is 
approximately twice as broad as long. The ornamentation pattern of $M$. bureaui varies according to the position of the scales on the body as well as during ontogeny (Fig. 2). Five types of ornamentation could be observed on the outer ornamented field: (1) coarse tubercles (co.tu), (2) coarse and short longitudinal ridges (co.ri), (3) fine leaf- or spoonshaped tubercles (sp.tu), (4) fine, parallel, longitudinal, low-profile ridges (f.ri), and (5) smooth, thinly and regularly pitted enamel surface (pi.e).

The coarse tubercles (co.tu) vary in shape from circular to ovoid. Occasional coarse tubercles located near the anterior-most limit of their distribution share the leaf-shape of the fine tubercles (Fig. 2C). The coarse tubercles are also found on the pectoral girdle and lateral gulars of $M$. bureaui. Although we consider that the coarse tubercles are a distinct category of ornamentation from the coarse ridges, these two types of ornamentation form a continuum. The coarse and short longitudinal ridges share similarities with the coarse tubercles. The coarse ridges (co.ri) are either linear or slightly curved, with the posterior extremity forming an apex. No bifurcation has been observed with the coarse ridges. In contrast to the fine low-profile ridges, the space between coarse ridges is broader than with the fine ridges. The longest ridges are found in the median region of the ornamented field. The median patch of coarse ridges is surrounded laterally and posteriorly by coarse tubercles. The 
coarse ornamentation has an extremely restricted distribution on the body (Fig. 2B-C).

The fine leaf- or spoon-shaped tubercles (sp.tu) occur only at the limit between the overlapped area (anterior field) and the ornamented area (posterior field). The tubercles are lanceolate to ovate and medially grooved with the apex pointing posteriorly. The size of these tubercles varies within a scale (Fig. 2C-E). Similar tubercles located in a similar position are also found in Miguashaia grossi (Forey et al., 2000, fig. 6B: most likely the two insets of figure 6B have been inverted).

The fine ridges (fi.r) are mostly linear and without bifurcation (Fig. 2D1,E). There are five (e.g. MHNM 06-2414) to $\operatorname{six}(e . g$. MHNM 06-1233) ridges per $\mathrm{mm}$. Individual ridges are approximately $0,16 \mathrm{~mm}$ in width. Most ridges are linear; however, marginal ridges may be slightly curvilinear in the largest specimens. On each scale, there are few ridges that bifurcate anteriorly or posteriorly. Occasionally, adjacent ridges merge along their length, thus keeping their respective width. Along the merged sections, spaces are left unmerged forming small pores $(0.16-0.18 \mathrm{~mm}$ in length and $0.03 \mathrm{~mm}$ in width) that result in a pitted surface. In contrast to $M$. bureaui, the longitudinal ridges of $M$. grossi radiate from the medial axis of the scale (Forey et al., 2000, fig. 6B). The pitted enamel surface (pi.e) covers from the posterior margin of the posterior field up to the complete ornamented 
area (Fig. 2E). The pores are ovoid to fusiform; the origin of the pores comes from the merging of adjacent ridges. The pores are aligned longitudinally in the prolongation of the interridge space as well as across the width of the scale. Along a longitudinal alignment, there is a spacing of approximately 0.25-0.27 mm. During growth, this condition originates at the posterior margin of the scales and progresses anteriorly up to the condition in which the complete ornamented area is covered by a pitted surface. The pitted enamel surface was referred as the "almost continuous enamel covering" by Forey (1998, p. 329).

In agreement with Cloutier (1996), the ornamentation of the posterior field of a scale differs in relation with its position on the body. Few scales from the anteroventral region of the body bear coarse tubercles and coarse ridges (MHNM 0641, MHNM 06-641, MHNM 06-1809) (Fig. 2C). Flank scales from the anterior region of the trunk present a narrow area of small leaf- or spoon-shaped tubercles (anteriorly) and fine longitudinal ridges and a pitted enamel surface (posteriorly). Flank scales from the posterior region of the trunk are either covered by (1) fine leaf- or spoon-shaped tubercles and fine longitudinal ridges (Fig. 2D1) (MHNM 06-1633, MHNM 06-1236), (2) fine leaf- or spoon-shaped tubercles, fine longitudinal ridges and pitted enamel surface (MHNM 06-1234), (3) fine longitudinal ridges and pitted enamel surface (Fig. 2E) (MHNM 06-494, MHNM 06-1265, MHNM 06-1809), or (4) solely pitted 
enamel surface (MHNM 06-1237, MHNM 06-1265). The extent of the pitted enamel surface increases during growth in order to cover the complete ornamented area. Smaller scales from the caudal lobe only bear fine longitudinal ridges in both small and large individuals (MHNM 06-1318, MHNM 06-1809). Although the ornamentation is not preserved on the complete specimens, the smallest individuals appear to only have fine longitudinal ridges (ULQ 120, MHNM 06-1633). The coarse tubercles and ridges seem to develop only in larger individuals (MHNM 06$641)$.

The inner surface of the scales is flat and characterized by small circular bumps (ci.b) perforated in their centre (Fig. 2D2); these structures had already been reported and illustrated by Cloutier (1996, fig. 17D). Although small, these bumps vary slightly in diameter. They do not seem to be aligned. These bumps are located at the level of the outer ornamented area (posterior field). As far as we know, Miguashaia bureaui is the only sarcopterygian species with this feature. The posterior part of the inner surface shows fine concentric circuli (growth lines) with some variations in terms of width bands and inter-band spacings.

Sensory lateral line scales had been reported by schultze (1973) and Cloutier (1996) on a juvenile specimen (holotype ULQ 120). While Schultze (1973, fig. 1a) illustrated scales with one central elongated canaliculus per scale forming a horizontal trajectory starting at the posteroventral limit of 
the anocleithrum, Cloutier (1996, fig. 1a) illustrated scales with one central elongated canaliculus associated with two pores above and below forming also a horizontal trajectory on most of the length of the trunk but slightly curving dorsally along the anocleithrum. Seven to eight scales belonging to the anterior section of the main lateral line canal are preserved on specimen MHNM 06-1236 starting above the dorsal part of anocleithrum. Each scale has the main elongated canaliculus flanked dorsally and ventrally by three or four slightly curving canals.

\section{Histology}

In both specimens used for the histology study (MHNM 06-1238 and MHNM 06-1495) (Fig. 1), the scales are imbricate and preserved in articulation. The inner surface of scales is best preserved in specimen MHNM 06-1238 showing the complete shape of the scales (average diameter of $1.5 \mathrm{~cm})$ ( $\mathrm{SC}, \mathrm{Fig} .1 \mathrm{~A})$. The inner surface is generally smooth and displays a few weakly marked growth rings and scattered bumps in the central and posterior regions (Fig. 2D2). In addition, there is a patch of imbricated scales showing the outer field with the fine longitudinal ridges. The scales from MHNM 06-1495 (average diameter of $1.7 \mathrm{~cm}$ ) are visible on their external surface (sc, Fig. 1B). Most scales are preserved as imprints showing either fine longitudinal ridges or pitted enamel surface; these scales are most likely from the anterior region of the flanks. 
A few well-preserved scales (most likely anteroventral scales) show large tubercles as well as leaf-shaped tubercles and fine longitudinal ridges.

\section{The exposed area (posterior field)}

The scales can be microstructurally divided into three well defined superimposed portions (Fig. 3): 1) a superficial layer of odontodes (od) made of enamel (e) and dentine (d) (Figs 3A, $4 A-C)$, 2) a middle layer (ml) of vascular, woven-fibered bone (vb) with numerous vascular canals (i.e., spongiosa) (Figs 3B, 5, 6), and 3) a basal plate (bp) made of parallel-fibered lamellar bone (lb) (i.e., isopedine) (Figs 3C, 7). The enamel and dentine layers form the tubercles and the ridges ornamenting the exposed area. Certain odontodes display a pointed or concave lenticular outline in cross-section (Figs $3 \mathrm{~A}, \quad 4 \mathrm{~B}-\mathrm{E})$.

Enamel. The enamel is a single uniformly developed sheet of approximately 15-25 $\mu \mathrm{m}$ in thickness (e, Figs 3A, 4B-E). No cytoplasmic prolongations from the dentine are present in the enamel, thus ruling out the occurrence of enameloid. The enamel only occurs in the tubercles and is restricted to their tips. No continuous sheet of enamel has been distinctly observed in our two sectioned specimens but we suspect that it displays identical features to the enamel of the odontodes.

Dentine. The dentine layer forms the base of the odontodes (d, Figs 3,4) and is variable in thickness (between 50-100 $\mu \mathrm{m}$ ). 
Dentinal tubules (oc, odontoblastic canaliculi) (Fig. 4B) are roughly perpendicular to the enamel layer; these radiate from small odontoblastic cavities (pc, pulp cavities) located at the base of the dentine layer (Fig. 3A). The dentine of Miguashaia bureaui can thus be described as orthodentine (Francillon-Vieillot et al., 1990). At least two generations of superimposed odontodes occur in some sections (Fig. 3A, 4DE), with partial resorption of the older generation by the surrounding cellular bone. Cosmine is confidently considered absent as there is no evidence of a pore-canal system developed between the enamel, dentine and vascular bone. Spongiosa. A middle vascular bone layer (i.e., spongiosa) occurs between the odontodes of the superficial layer and the isopedine layer of the basal plate. It is formed of wovenfibered bone pervaded by numerous primary vascular canals (vb, Figs 3A-B, 4B-E, 5). As the dentine layer, the spongiosa is well-developed but varies in thickness (approximately between 50-100 $\mathrm{mm}$ ) across the scales. Numerous osteocytic lacunae with their ramified canaliculi can be seen (Figs 3B, 4D, 6D-F). Horizontally-connected vascular canals are located below the dentine and surround the buried odontodes. Some of these vascular canals open through the external surface (vc, Fig. 4B-C). The woven-fibered bone of the spongiosa forms the radial striae of the overlapped area of the scales (vb, Fig. 6A) in the form of pointed or mushroom-like projections of compact bone (vb, Figs 5B, 7A). Secondary vascular canals can 
be seen (Fig. 6C,D,E) indicating the presence of localized osteonal remodelling.

Isopedine. The basal plate is made of a fully mineralized, lamellar bone with a plywood-like structure with a variable orientation of the collagen plies (1b, Figs 3C, 4C-E, 7B). The isopedine layer accounts for one third to half of the scale total thickness (approximately between 100-150 $\mu \mathrm{m}$ ). The plies of the basal plate are made of thick collagenous fibres, organized in bundles that appear roughly quadrangular in cross section (Fig. 3C). There is only one layer of fibres per ply with each ply being about 10 to 20 um thick. Horizontal sections of the basal plate confirm that collagenous fibres are parallel to each other in a given ply. The direction of the fibres rotates from a given ply to the next (Figs 3C, 7B). We have observed the presence of five fibrillary directions (Fig. 8A), indicating that a repetitive pattern occurs every five layers (Figs 3C, 7B) and that each fibre rotates from one layer to the next with an angle of approximately $36^{\circ}$, thus constituting a twisted plywood. But contrary to the basal plate of the scales of Latimeria (Fig. 8B,C), no arciform patterns, characteristic of a double-twisted plywood (Giraud et al., 1978a,b; Meunier, 1981; Mondéjar Fernández \& Meunier, 2020), occur in transversal section, thus indicating that the isopedine of the scales in Miguashaia bureaui is composed of a simple twisted plywood. Several small osteocytic lacunae and canaliculi are visible between the plies, showing that the 
collagenous network enclosed elongate osteocytes (elasmocytes sensu Meunier, 1984; Francillon-Vieillot et al., 1990) with their cytoplasmic processes extending along the collagen fibres (Figs 4C-D, 8A). Many vertical vascular canals orthogonally cross the isopedine layer and several open through the internal surface forming a bulge (Fig. 7B), corresponding to the perforate small circular bumps of the internal surface (Fig. 2C). In some sections, the irregular contact of the collagen plies at the internal (or visceral) margin of the scales (Figs 4A, 5A, 7B) may indicate the occurrence of Mandl's corpuscules attesting to a possible delay between collagenous synthesis and its mineralization (see Schönborner et al., 1981 for teleostean elasmoid scales) in successive mineralization events across the basal layer (Fig. 4A)

\section{The overlapped area (anterior field)}

The upper part of the superficial layer (sl) of the area overlapped by the adjoining scales is generally deprived of odontodes, yet it shows a superficial ornamentation composed of a layer of compact acellular bone (Fig. 5A, C) that recalls the external layer of the teleostean elasmoid scales (Francillon-Vieillot et al., 1990; Zylberberg et al., 1992). This external acellular ornamented layer overlays a vascularised layer of cellular bone (Fig. 5B). The vascular canals appear to be more uniformly distributed than in the 
exposed area (sl, Fig. 7A) and open regularly onto the surface between the small striae made of woven-fibered bone (Figs 5, 7A). The basal plate has a slightly greater relative thickness than in the posterior field but displays the same organization and a similar number of stacked layers of collagenous fibres (Fig. 5A) .

\section{DISCUSSION}

\section{Histology of Miguashaia and comparisons}

Despite their rich fossil record, comprising more than 60 genera and 130 species (Cloutier \& Forey, 1991; Forey, 1998), few surveys of the dermal skeleton of coelacanths have been undertaken. Gross (1966:42) first noted that the scales of coelacanths had barely changed their histological and microstructural organisation during their long evolutionary history, a statement that was later reprised in subsequent reviews of coelacanth evolution (e.g. Janvier, 1996; Forey, 1998). To our knowledge, few detailed accounts on the palaeohistology of the scales and dermal bones of extinct coelacanths have been published or properly illustrated. These include most notably histological reports on Macropoma lewesiensis (Williamson, 1849), Coelacanthus granulatus (Goodrich, 1907), Undina penicillata (Gross, 1935, 1966), Diplurus newarki and Chagrinia enodis (Schaeffer, 1952, 1962), and Spermatodus pustulosus (Meinke, 1982). Indeed, many 
descriptions of paleohistological features are either solely based on external observation, drawings, or en unfigured thin sections (e.g. Schaeffer, 1952; Forey, 1998). As such, the reliability of many descriptions is difficult to assess due to the lack of proper illustrations since because no description can consistently capture all the information contained in a histological section.

The thin, imbricate round scales of all histologically studied coelacanths, as evidenced here in Miguashaia (Figs 3, 4A, 7A), display in the posterior field three well-defined portions, differing in their microstructure: 1) a superficial layer of odontogenic components (odontodes generally made of enamel and dentine), 2) a middle layer composed of vascular bone (spongiosa) and 3) a basal plate made of lamellar bone (isopedine). The combination of this microstructural arrangement with a rounded outline allows to ascribe the scales of coelacanths to the elasmoid type (Bertin, 1944; Smith et al., 1972; Castanet et al., 1975; Miller, 1979; Meunier \& Zylberberg, 1999; Hadiaty \& Rachmatika, 2003; Meunier et al., 2008), a scale morpho- and histotype that is widely spread and convergently acquired in osteichthyans (e.g. Francillon-Vieillot et al., 1990; Schultze, 1977, 2015, 2018 ; Mondéjar-Fernández \& Meunier, 2020). The general structure of the elasmoid scales displayed in Miguashaia has been maintained across coelacanth evolution until the Recent as evidenced in Latimeria (Castanet et al., 1975; Meunier et al., 
2008), although the ornamentation patterns, ossification rate, and relative thickness of the various layers differ across taxa. Nevertheless, several key differences can be recognized between certain taxa, revealing a significant histological disparity.

The superficial layer comprises the outer ornamentation of the exposed area of the scales, which is composed of pointed to rounded tubercles and/or ridges, variable in width and number within as well as between taxa (e.g. Miguashaia, Diplocercides, Spermatodus) (Table 1). The presence of ridges has been noticed in numerous extinct coelacanths (e.g. Diplurus, Rhabdoderma, Axelrodichthys, Holophagus) (Forey, 1998). In many instances, their shiny appearance is suggestive of the odontogenic nature of these ridges, composed either solely of dentine or more likely covered by enamel (e.g. Diplocercides, Rhabdoderma, Axelrodichthys, Holophagus). However, few histological studies have been performed on the scales to confirm the putative universal occurrence of dentine, let alone the co-occurrence of enamel (e.g. Gross, 1935). For instance, the scales of Diplocercides (Stensiö, 1937) have not been histologically surveyed although Gross (1935:44) stated that in D. jaeckeli the small ridges were "certainly made of dentine". The scales of Macropoma are ornamented with elongate tubercles, with the largest ones occupying the central position in the exposed area (Forey, 1998, fig. 11.12). Most remarkably, the scales from the 
posterior half of the body display large pointed tubercles resembling "hollow cylinders" (Forey, 1998, fig. 11.12B). Williamson (1849, pl. XLIII 27,28) illustrated these tubercles in M. lewesiensis, confirming their odontogenic nature. The scales of Diplurus (Schaeffer, 1948, 1952) do not possess tubercles, only large ridges, probably odontogenic. Schaeffer (1952:52) stated that in D. newarki "the bones, and apparently also the scales, are covered by a thin layer of enamel", but this is difficult to confirm given that thin sections were not illustrated. Coelacanthus presents "elongated tubercles or shiny ridges" (Goodrich, 1907:766) that appeared as "hollow" in the poorly illustrated cross sections of C. granulatus (Goodrich, 1907, pl.XLIV 12). The odontode nature of these structures was not confirmed, but they might represent dentine tubercles with large pulp cavities capped with enamel or large vascular canals of the superior portion of the spongiosa. The odontodes of Undina penicillata (Gross, 1966, fig.7B) are remarkably composed exclusively of dentine and do not present enamel, as opposed to those of Miguashaia, Spermatodus and Macropoma. Noteworthy, Mawsonia appears to lack odontogenic ornamentation as the ridged surface of the dermal bones and scales has been described as being solely made of bone in $M$. brasiliensis (Yabumoto, 2002), although histological data have not been published. The ridges and tubercles of Chagrinia enodis (Schaeffer, 1962; Cloutier, 1996, fig. 9D) were also described as made of bone, although but according to Forey 
(1998), the absence of odontogenic ornamentation might be due to a preservation artefact. Other taxa described as displaying a "rugose" ornamentation of the scales (sensu Forey, 1998) such as Chinlea sorenseni (Schaeffer, 1967), are not suited to histological survey as the scales are preserved as impressions.

An ornamentation composed of tubercles and/or ridges is thus fairly common and widespread in the scales and dermal bones of coelacanths (Figs 9, 11). However, due to the lack of histological data for many taxa, it is currently difficult to determine whether it is consistently composed of odontogenic tissues and to study its ontogenetic development. In some Mesozoic taxa, the odontodes usually display large but shallow pulp cavities, connected to a horizontal network of vascular canals in the spongiosa (e.g. Undina, Macropoma). This condition, retained in Latimeria chalumnae (Roux, 1942; Ørvig, 1977; Castanet et al., 1975) (Figs 9, 10A), differs from that of Miguashaia bureaui, in which pulp cavities are reduced (Figs 3A, 4). A possible evolutionary trend can be proposed, from small and numerous odontodes with small pulp cavities in early Palaeozoic coelacanths (e.g. Miguashaia) to fewer but larger odontodes with wider pulp cavities in younger taxa from the Mesozoic (e.g. Undina, Macropoma) to the Recent (Latimeria).

Odontodes are rarely found isolated, either on the scales or on the dermal bones. Indeed, superimposed generations of 
odontodes embedded in the spongiosa are known in Miguashaia bureaui (Figs 3,4), Spermatodus pustulosus (Meinke, 1982), and Undina penicillata (Gross, 1936, 1966), but not in Macropoma lewesiensis (Williamson, 1849). For instance, the presence and distribution of odontodes in the dermal bones of spermatodus is similar to those of Latimeria, but in the former the old generations of odontodes are more robustly developed and less resorbed than in the latter (Meinke, 1982). This condition, also present in Undina, appears closer to that of early osteichthyans with large partially to non-resorbed odontodes (e.g. Andreolepis, Lophosteus, Psarolepis) (Qu et al., 2013, 2016; Jerve et al., 2016). The occurrence of separated and superimposed odontodes represents the primitive pre-cosmine condition in osteichthyans (Mondéjar-Fernández, 2018) since these odontodes (either in the form of tubercles and/or ridges) are found in stem osteichthyans like Andreolepis hedei (Gross, 1968; Qu et al., 2016), Lophosteus superbus (Gross, 1969; Jerve et al., 2016), Ligulalepis toombsi and Orvikuina sp. (Schultze, 1968), Dialipina (D. salgueiroensis and D. markae) (Schultze, 1968, 1977), and Naxilepis gracilis (Wang \& Dong, 1989). However, the condition of coelacanths may represent a return to the odontode-ornamented condition of certain stem osteichthyans (e.g. Andreolepis), probably derived from a cosmine-covered condition in more crownward stem osteichthyans (e.g. Psarolepis) and sarcopterygians (e.g. Styloichthys, see below), rather than a retention of a pre- 
cosmoid state as previously suggested (Smith, 1977, 1979; Schultze, 1977).

The middle layer of vascular bone is variably developed in the scales of coelacanths. In the case of taxa with superimposed odontodes, the older generations are surrounded by vascular bone and may show traces of resorption as seen in Miguashaia bureaui (Figs 3-6), Undina penicillata (Gross, 1966), and Spermatodus pustulosus (Meinke, 1982). The vascular bone layer is made of a cellular woven-fibered bone, as evidenced by the occurrence of numerous osteocyte lacunae concentrically arranged around the embedded odontodes and vascular canals (e.g. Miguashaia, Spermatodus, Undina) (Fig. 6C). In Miguashaia bureaui (Figs 4, 7A), Macropoma lewesiensis (Williamson, 1849) and Undina penicillata (Gross, 1935, 1966), the vascular canals of the spongiosa open to the surface through pores, and, when present, some of them are connected with the pulp cavities of the dentine. In Latimeria, the middle layer is extremely reduced but horizontally-connected vascular canals occur at the base of the odontodes (Smith, 1972; Castanet et al., 1975) (Fig. 10B). In Undina penicillata, Gross (1935) described the presence of Sharpey's fibres in the spongiosa, whereas Williamson (1849) described similar structures in Macropoma lewesiensis but identified them as dentinal tubules (odontoblastic canaliculi). No distinctive Sharpey's fibres have been confidently identified 
in the middle layer nor in the basal plate of the scales of Miguashaia bureaui.

The basal plate of the scales and dermal bones of actinistians is composed of a layer of lamellar bone with a plywood-like structure (i.e.t isopedine). The basal plate is well ossified in the scales of all extinct coelacanths (e.g. Miguashaia, Coelacanthus, Undina, Macropoma), but it is not in the extant Latimeria (Castanet et al., 1975; Meunier \& Zylberberg, 1999; Meunier et al., 2008). Generally, the basal plate is about as thick as the superficial and middle layers combined. However, in Macropoma lewesiensis (Williamson, 1849), the basal plate was described as being thinner than these layers, a condition that appears to be variably developed within taxa. On the contrary, in Latimeria, the unmineralized basal plate is greatly developed whereas the middle and superficial layers are reduced (Castanet et al., 1975; Meunier et al., 2008) (Fig. 10). In Miguashaia bureaui, the thickness of the isopedine varies depending on the location of the thin section across the scales: the basal plate appears relatively thicker in the anterior portion (overlapped area) than in the posterior portion (exposed area) of the scales (Figs 3C, 4, 5A, 7A).

The isopedine layer consists of a cellular lamellar bone that can present enclosed osteocytes, as in Miguashaia bureaui (Figs 4C,D, 7B, 8A), Spermatodus pustulosus (Meinke, 1982) and Undina penicillata (Gross, 1935, 1966). In S. pustulosus, the 
isopedine from the dermal bones shows traces of secondary ossification (Meinke, 1982), as in the lateral line scales of Latimeria chalumnae (Meunier 1980, figs- 14, 15). Vertical vascular canals can also occur in the scales of Macropoma lewesiensis (Williamson, 1849) and in Miguashaia bureaui (Fig. 7B). The isopedine of Miguashaia has a twisted, plywood-like structure, similar to that of Latimeria and possibly other extinct coelacanths with well-developed lamellated basal plates (Fig. 8). However, it differs from the isopedine of Latimeria in being fully mineralized and in the lamellar bone being simply twisted, as opposed to the double-twisted arrangement in Latimeria (Giraud et al., 1978a,b; FrancillonVieillot et al., 1990). A double-twisted plywood is also known to occur convergently in other extinct sarcopterygians with rounded scales, like in the tetrapodomorph Eusthenopteron foordi (Zylberberg et al., 2010) and the dipnomorph Holoptychius sp. (Mondéjar-Fernández \& Meunier, 2020), as well as in the living dipnoans Neoceratodus forsteri, Lepidosiren paradoxa and Protopterus ( $P$. annectens and $P$. aethiopicus) (Meunier \& François, 1980). The twisted condition is thus commonly found in round-scaled sarcopterygians and appears to be derived from a primitive orthogonal arrangement of the isopedine present in stem osteichthyans (e.g. Psarolepis) (Qu et al., 2013) and many sarcopterygians with rhombic scales (e.g. Porolepis, Osteolepis) (Mondéjar-Fernández \& Meunier, 2020). However, given the current availability of 
paleohistological data on fossil coelacanth material, it is unclear whether a double-twisted plywood is an autapomorphy of Latimeria or if it was inherited from closely-related taxa. Finally, it is now well established that the irregularly mineralized basal plate of the scales of Latimeria derives from the fully mineralized basal plate of closely-related extinct coelacanths and is topologically and structurally homologous to the isopedine layer from other early sarcopterygians (e.g. early actinistians like Miguashaia, dipnomorphs like Porolepis, Holoptychius and Dipterus, and tetrapodomorphs like Megalichthys and Eusthenopteron) (Mondéjar-Fernández \& Meunier, 2020).

\section{Scale development and ontogeny}

Information on the development and patterning of the squamation in coelacanths is available through the study of the extant Latimeria. Smith (1979) showed that in the scales of Latimeria the odontodes develop separately from the basal plate (isopedine) and later fuse to it. In embryos of Latimeria, the odontodes are firmly associated with the vascular bone of the spongiosa and these develop synchronously after differentiation of the layers of the basal plate. During growth and development of the scales, supplementary odontodes and more spongy bone are added centrifugally and some occur superimposed onto the earlier generation (Fig. 10A; Roux, 1942: Smith et al., 1972; Ørvig, 1977; Smith, 1979). 
Developmental data on Latimeria thus matches developmental (Sire \& Huysseune, 2003) and evolutionary (Sire et al., 2009) scenarios of the squamation in osteichthyans as the development and evolution of the squamation appear to occur on two levels, matching the two main portions of the scales: 1) the odontogenic component (neural crest-derived) comprising the combination of the superficial odontode-bearing layer and associated vascular bone from the middle layer, and 2) the osteogenic component (mesodermally-derived) represented by the basal plate. The superficial layer and basal plate of the scales of osteichthyans show independent patterning and evolutionary trends, consistent with separate developmental origins (Gillis et al., 2009), a pattern that can be identified from the first manifestations of the dermoskeleton in early vertebrates (Donoghue et al., 2006). Microanatomical and histological changes of tissues (e.g. loss of cosmine, modification of odontode shape and pattern of distribution) can occur in the superficial layer of the scales without affecting the basal plate, and vice-versa (e.g. loss of mineralization of the isopedine), revealing the independence of the cell lineages responsible for the odontogenic and osteogenic components of the dermal skeleton (Schaeffer, $1977)$.

Unfortunately, little information is available on the development of the squamation in extinct actinistians. Ontogenetic series are fairly rare and embryonic or early 
juvenile stages are solely known Miguashaia bureaui (Schultze, 1973; Cloutier, 1996; Cloutier et al., 2009), Serenichthys kowiensis from the Devonian of South Africa (Gess and Coates, 2015), Rhabdoderma exiguum from the Carboniferous of the USA (Schultze, 1972, 1980; Cloutier, 2010), Caridosuctor populosum, Hadronector donbairdi and Polyosteorhynchus simplex from the Carboniferous of the USA (Lund and Lund, 1985), Luopingcoelacanthus eurylacrimalis from the Triassic of China (Wen et al., 2013), Undina penicillata from the Jurassic of Germany (Watson, 1927; Clack, 1996), Axelrodichthys sp. from the Cretaceous of Brazil (Brito and Martill, 1999), and a juvenile coelacanth from the Carboniferous of Germany (Witzmann et al., 2010). The most diagnostic character to recognize juvenile coelacanths is the distinctly longer supplementary lobe of the caudal fin relative to that of adults. Miguashaia (Cloutier, 1996) and Gavinia (Long, 1999) are considered morphologically primitive coelacanths by the possession of an heterocercal caudal fin lacking a supplementary lobe as opposed to more derived and anatomically modern coelacanths with a characteristic trilobed diphycercal caudal fin (Zhu et al., 2012). However, in Miguashaia, the notochordal lobe is proportionately much longer in juveniles (Cloutier et al., 2009).

Developmental studies on extant osteichthyans (e.g. Danio) have shown that the squamation develops gradually across the body, usually starting posteriorly, at the level of the caudal 
peduncle, and progresses anteriorly following the lateral line (Sire \& Akimenko, 2004), a pattern that can be confidently transposed to fossil ontogenies of extinct taxa, with minor differences (Cloutier, 2010). The date of appearance of the first scales is still unknown in Latimeria, but embryos found in the oviducts of the females of L. chalumnae can be up to 13 months old before birth, and display two lines of arrested growth (Hureau \& Ozouf, 1977). However, the squamation is rarely preserved in juvenile coelacanth fossil specimens as scales are among the latest elements to ossify during the ontogeny, and this usually prevents fossilization. One noteworthy exception is Rhabdoderma exiguum for which small yolk-sac embryonic specimens (e.g. YPM 2024, $24.2 \mathrm{~mm}$ in standard length; FMNH PF 5521) display extremely thin scales present throughout the complete body and are ornamented with small longitudinal ridges (R.C., pers. observ.). The case of Miguashaia bureaui is also remarkable since juvenile as well as adult specimens are known in which the squamation is fully developed and preserved (Schultze, 1973; Cloutier, 1996).

The variation in the ornamentation of the gular plates and scales has been listed among the main ontogenetic changes occurring in Miguashaia (Cloutier, 1996). In the case of the scales, the extent of the pitted enamel surface increases during growth, from juveniles with incompletely covered exposed areas in the posterior portion of the trunk to adults displaying a fully sheeted ornamented area (Fig. 2E). It has 
also been shown that small individuals mainly display fine longitudinal ridges across the body (ULQ 120, MHNM 06-1633), while coarse tubercles and larger ridges are mainly found in larger individuals (MHNM 06-641). In the small juveniles, the internal surface of the scales lacks the small circular bumps which become visible only in adult specimens (Fig. 2D2). Ornamentation variation across the ontogeny is also known in Rhabdoderma exiguum in which the ornamentation of posterior scales is more pronounced than in the anterior part of the body (e.g. FMNH PF 5760) and the number of longitudinal ridges increases from embryonic to juvenile specimens.

Remodeling of bone, which produces structures such as the secondary vascular canals in Miguashaia bureaui (Fig. 4E, 6), is also evidence of advanced ontogenetic growth (Dias \& Richter, 2002) and may be related to sexual maturity in these specimens.

The development of larger tubercules and ridges has been associated with the function of tubercles as a reinforcement of the adhesion properties between the scales and the overlying epithelium (Burdak, 1979). The shape and localization of these tubercules across the body are also related to the control of the water flow during swimming throughout ontogeny, as evidenced in extant osteichthyans (e.g. Mugil) (Burdak, 1979). The ornamentation in Latimeria does not vary significantly during ontogeny, with the only exception of the number of tubercles, which are less numerous 
in juvenile specimens due to the small size of the scales, and more abundant in adult specimens with larger scales.

Growth rings (annuli) are frequently encountered in the scales of extant and extinct osteichthyans and they occur in the overlapped area of the scales of many early coelacanths (Fig. 11) and of Latimeria. These annuli have been counted in L. chalumnae (Hureau \& Ousouf, 1977; Millot \& Anthony, 1978), where juvenile specimens have fewer annuli than adult ones, and assuming that each ring represents a seasonal or annual line of arrested growth, a putative age can be assigned to specimens based on isolated scales. In L. chalumnae, two episodes of arrested growth (January-February and AugustSeptember) occur each year during the dry season (Hureau \& Ozouf, 1977), allowing to assign a relatively accurate age to specimens caught in the wild. In Miguashaia bureaui equally spaced annuli are present in large adult specimens (e.g. MHNM 06-641, 06-1232, 06-1236, 06-1239, 06-1809) and are more numerous than in smaller individuals. P; peripheral growth rings are more closely spaced towards the periphery of large scales, congruent with the acquisition of sexual maturity and a slower growth rate in adults. Approximative ages could also be given to fossil specimens but these estimations can be less reliable given the tentative reconstruction of the paleoenvironnements in which these forms lived and the uncertainty regarding the metabolism, food supply, competitive 
stress, salinity and duration of the seasons, among other possible factors.

\section{Evolutionary trends of the squamation in coelacanths}

Among other synapomorphies, coelacanths are characterized by the possession of rounded scales (Janvier, 1996; Forey, 1998). However, the squamation of actinistians is rarely composed of perfectly circular scales. The scales can either be roughly circular (e.g. in early forms like Miguashaia and Diplocercides) or subcircular (oblong to oval), with a slightly quadrangular anterior margin (e.g. Guizhoucoelacanthus, Latimeria). Other taxa possess ovate scales, with a pronounced posterior edge that may display a rounded (e.g. Sassenia, Whiteia) or pointed margin (e.g. Lualabea, Diplurus, Rhaboderma). Given the morphological plasticity of the squamation, the body size variation, and the relative environmental cosmopolitanism of coelacanths across their evolutionary history, no distinctive trend can be depicted for the evolution of the scale outline; however, the earliest taxa (e.g. Miguashaia, Diplocercides) display the most circular contour whereas in more recent forms the scales become more antero-posteriorly elongated and the posterior margin displays a more variable profile, with different degrees of acuteness (Fig. 11).

The size, extension, and combination pattern of tubercles and ridges that occur on the exposed area is also extremely 
variable (Forey, 1998). In many genera, the size and distribution of the ridges and tubercles are homogeneous (e.g. Rhabdoderma, Caridosuctor, Holophagus and Latimeria) but some taxa display a differentiated ornament in which large ridges usually located in the central portion of the exposed area are associated with smaller ridges that are distributed laterally (e.g. Axelrodichthys, Chinlea, Diplurus, Heptanema, Lualabea, Mawsonia) (Forey, 1998, Yabumoto, 2008; Renesto \& Stockar, 2018; Fragoso et al., 2019). This condition appears to be especially developed in the Mawsoniidae (Fig. 11) and may constitute a shared derived feature of these taxa but further phylogenetic inquiry is needed to confirm it.

Vornamental variations of the ornamentation have been used to discriminate taxa and thus have a taxonomic value at generic or species levels (e.g. various species of Rhabdoderma and Whiteia) (Table 1). In completely preserved specimens, ornamentation variation has been observed to occur over various regions of the body (e.g. Miguashaia, Macropoma, Luopingcoelacanthus) (Cloutier, 1996; Forey, 1998; Wen et al., 2013) (Fig. 2) and thus taxonomic identification must be cautious when describing new taxa based solely on isolated scale remains. A general evolutionary pattern nevertheless emerges, in which the earliest coelacanths (e.g. Miguashaia, Diplocercides) tend to show numerous tubercles or ridges, whereas younger taxa (e.g. Rhabdoderma, Diplurus, Latimeria) display fewer but larger tubercles and ridges (Figs 2C, 11). 
By contrast, the overlapped area of the scales is not ornamented, excepted in some Devonian taxa like Miguashaia, Gavinia, and Diplocercides, which display a reduced field of small leaf- or spoon-shaped tubercles spanning the margin between the overlapped and exposed areas (Figs 2C-E, 11). These small odontodes are also characteristic of other Devonian sarcopterygians (e.g. onychodonts, porolepiforms, early dipnoans), where they may occur associated with a welldeveloped cosmine sheet (e.g. the porolepiforms Porolepis, Heimenia, and the early dipnoan Uranolophus) (Ørvig, 1957, 1969; Denison, 1968; Mondéjar-Fernández \& Clément, 2012) or not (e.g. the porolepiforms Holoptychius, Glyptolepis, and Laccognathus, and the onychodonts Onychodus and Selenodus) (Ørvig, 1957; Cloutier \& Schultze, 1996; Andrews et al., 2006; Mondéjar-Fernández, 2020). Such small odontodes thus represent a primitive shared feature of sarcopterygians. Past the Carboniferous, coelacanth scales lost this type of tubercles, yielding a relatively smooth overlapped area and fewer and larger tubercles and ridges in the exposed area (e.g. Caridosuctor, Rhabdoderma, Axelrodichthys) (Fig. 11).

The overlapped area generally occupies between a half and two thirds of the external surface of the scales of coelacanths. However, the isolated scale material is scarce in many post-Devonian taxa and thus neither the smoothness nor the precise contour of the overlapped area can be properly described or illustrated in these taxa (see Forey, 1998). In 
the scales from the posterior part of the trunk of Miguashaia bureaui, the ornamented exposed area is almost as developed as the overlapped area with a roughly 50/50 ratio (Fig. 2B,E), most probably representing the primitive condition in actinistians. Other Devonian taxa such as Diplocercides also display an important exposed area relative to the overlapped area (Fig. 11). However, the anterior portion of the overlapped area is slightly more developed and tend to widen relative to a narrower posterior portion of the exposed area, a pattern that is accentuated in post-Devonian forms (e.g. Diplurus, Axelrodichthys, Guizoucoelacanthus, Latimeria). The internal surface of the scales is poorly-known in extinct coelacanths as few specimens preserve the scales in internal view. To our knowledge, the internal surface has solely been described among Palaeozoic coelacanths in Miguashaia bureaui, where small numerous bony bumps occur in the posterior region (Fig. 2D2). In Mesozoic forms, the internal surface of the scales is preserved in the Triassic Luopingcoelacanthus eurylacrimalis (Wen et al., 2013), the Jurassic Indocoelacanthus robustus (Jain, 1974), and the Cretaceous Megalocoelacanthus dobiei (Dutel et al., 2012) where it is smooth but concentric growth rings are well developed. The scales of the extant Latimeria have a smooth, slightly concave but otherwise featureless, internal surface. Foreyia maxkuhni from the Triassic (Cavin et al., 2017) is an interesting case as numerous scales from the trunk and base of 
the fins are known. The internal surface is generally smooth but in some portions of the body a drop-shaped boss is clearly visible (Cavin et al., 2017, fig. 2.4,5,8). This feature is reminiscent of the distinctive drop-shaped boss of certain Devonian sarcopterygians like rhizodonts and tristichopterids (Jarvik, 1980). The phylogenetic history and significance of this character is difficult to retrace. Its occurrence in Foreyia may represent the result of a simplification of the pattern seen in Miguashaia with numerous bumps or an independently acquired convergent feature with Devonian tetrapodomorphs.

\section{The early evolution of the coelacanth scales}

Two enigmas remain in the early evolution of eoclacanth's the squamation in coelacanths: 1) did coelacanths lose cosmine (as in many other sarcopterygian groups during the Devonian), or was cosmine never present in their ancestors? and 2) was the primitive scale morphotype of coelacanths rhombic or rounded? Indeed, Miguashaia and Gavinia, the currently considered basal-most undisputed coelacanths (Zhu et al., 2012; Gess \& Coates, 2015) display rounded scales without cosmine and ornamented with the classical odontogenic combination of tubercles and ridges. The position of the putative actinistian Styloichthys and the likely sister-group relationship between coelacanths and onychodonts among early sarcopterygians are 
key to answer these questions, however both issues are still unsettled.

Styloichthys changeae from the Lochkovian (Lower Devonian) of China was initially described as the sister-group of rhipidistians (defined as the largest clade that includes all taxa more closely related to tetrapods and diponans than to actinistians) (Zhu \& Yu, 2002) and this position has been subsequently confirmed in other analyses (e.g. Zhu et al., 2006, 2009; Lu et al., 2016a,b). However, after Friedman's (2007) new interpretation, its status as a putative early coelacanth has started to gain acceptance (e.g. Gess \& Coates, 2015; Lu et al., 2017). Styloichthys displays shared derived characters of the lower jaw, braincase and dermal skull with coelacanths (Friedman, 2007), however, as opposed to other actinistians, Styloichthys presents rhombic cosmoid scales (Lu \& Zhu, 2008; Cui et al., 2019), similar in shape to those of early dipnomorphs (e.g. Youngolepis) (Chang \& Smith, 1992) and tetrapodomorphs (e.g. Kenichthys) (Chang \& Zhu, 1993). Cross sections performed în the dermal shoulder girdle (cleithrum), but not in the scales, show that styloichthys possesses a peculiar type of cosmine in which large odontodes are associated with a pore-canal system that opens to the surface through wider pores than in rhipidistians (i.e., dipnomorphs and tetrapodomorphs) but similar to other early osteichthyans (e.g. Psarolepis and Meemannia) (Zhu et al., 2006; Qu et al., 2013; Mondéjar-Fernández, 2018). In Styloichthys, the pore- 
canal system is embedded in several layers of enamel and dentine, organized as superimposed odontodes (Zhu et al., 2006, 2010). This condition differs from the classical "true" cosmine (eucosmine) of rhipidistians where a single layer of enamel overlays the dentine (Sire et al. 2009; MondéjarFernández 2018) and highlights that Styloichthys exhibits a primitive type of cosmine, similar to that of stem osteichthyans like Psarolepis and Achoania, and early actinopterygians like Meemannia (Zhu et al., 2006, 2010; eu et al., 2013, 2016; Lu et al., 2016b).

The case of onychodonts is also of interest when dealing with the primitive condition of the squamation in actinistians. A close relationship between onychodonts and coelacanths has been proposed in numerous recent studies of sarcopterygian interrelationships (e.g. Zhu et al., 1999, 2001, 2006, 2009; Botella et al., 2007; Lu \& Zhu 2010; Lu et al., 2016b, 2017; Clement et al., 2018) and it is currently suspected that onychodonts might represent a paraphyletic group of stem actinistians (Lu et al., 2016a; MondéjarFernández, 2020). However, this result complicates the reconstruction of the primitive scale morpho- and histotype in coelacanths. The scales of all known onychodonts are rounded, except in Qingmenodus yui from the Pragian (Lower Devonian) of China, for which the scale shape is still unknown (Lu \& Zhu, 2010; Lu et al., 2016a). The exposed area of the scales is classically ornamented with characteristic pointed tubercles, 
confirmed to be odontodes made of dentine capped with a thin enamel layer in Selenodus aquesbiae from the Eifelian (Middle Devonian) of Morocco (Mondéjar-Fernández, 2020). In the earliest undisputed onychodont Bukkanodus jesseni from the Pragian of Australia (Johanson et al., 2007), the exposed area is ornamented with wide dentine ridges separated by grooves containing pores. The odontodes of onychodonts are histologically identical to those of coelacanths like Latimeria (Castanet et al., 1975; Meunier et al., 2008), and now also confirmed in Miguashaia (Figs 3,4), which probably represents a primitive shared condition of onychodonts and actinistians. Absence of cosmine is also a diagnostic feature for of onychodonts (Andrews et al., 2006). However, putative onychodont remains from the Lower and Middle Devonian of China are covered with cosmine (Zhu \& Yu, 2004; Zhu \& Zhao, 2005; Lu \& Zhu, 2010). The dermal skull bones of Qingmenodus display a shiny coating, probably made of enamel, and closely spaced tiny pores, but no histological information is available to confirm or refute the occurrence of cosmine (Lu \& Zhu, 2010; Lu et al., 2016a). It would thus not be surprising that new material from early onychodonts present cosmine, which would suggest that the cosmine was lost in younger onychodonts and actinistians.

The current phylogenetic picture of coelacanth interrelationships within sarcopterygians evidences two problems that complicate the unravelling of the origin of the 
coelacanth squamation (Fig. 12A). If Styloichthys is considered as the oldest coelacanth and the sister-group of all other actinistians (Friedman, 2007; Gess \& Coates, 2015), then 1) a rhombic and cosmoid morpho- and histotype may be primitive for coelacanths, which implies that 2) the acquisition of a rounded shape and the loss of cosmine probably occurred during the Lower-Middle Devonian, as displayed in Miguashaia, Gavinia and Diplocercides (Fig. 11). However, this scenario is at odds with the supposed sistergroup relationship of onychodonts and coelacanths, especially if onychodonts are no longer considered a monophyletic group but a subset of stem actinistians (Lu \& Zhu, 2010; Lu et al., 2016a,b, 2017; Mondéjar-Fernández, 2020). In this latter case, the evolution of a cosmoid rhombic morphotype of styloichthys from the rounded and cosmine-lacking scales of onychodontids implies a reversal (Fig. 12B).

A series of plausible scenarios could reconcile the phylogenetic position of styloichthys with the close relationship of onychodonts and coelacanths and parsimoniously account for the evolutionary origin of the actinistian squamation. The position of Styloichthys has been reconstructed as shifting between the sister-group of the onychodont-actinistian clade (Lu et al., 2016b) (Fig. 12C) and the sister-group of a more inclusive taxon that includes the onychodont-actinistian clade and rhipidistians (Lu et al., 2017) (Fig. 12D). If either of these hypotheses are further 
supported by new fossil and phylogenetic data, then it will corroborate that the combination of a rounded scale morphotype and the ridged/tuberculated ornamentation of onychodonts and coelacanths is a shared feature. Rounded scales devoid of cosmine might have evolved from primitive cosmoid scales similar to those of early sarcopterygians like styloichthys (Fig. 12C) or from early cosmine-covered onychodonts (Fig. 12D) before the establishment of the rounded morphotype in the common ancestor of more recent onychodonts (like Bukkanodus, Selenodus, Onychodus or Strunius) and actinistians.

The last possible scenario is to consider onychodonts as stem sarcopterygians, not closely related to actinistians, but rather as the sister-group of a clade comprising coelacanths (including Styloichthys) and rhipidistians (e.g. Cloutier \& Ahlberg, 1996; Friedman, 2007) (Fig. 12E). In this case, the acquisition of a rounded and tuberculated squamation is convergent in onychodonts and actinistians, and both originated from a rhombic ancestral morphotype covered in cosmine, similar that of stem osteichthyans like Psarolepis (Qu et al., 2013). In the case of onychodonts, primitive cosmoid forms may be represented by the putative cosminecovered onychodonts from China (Zhu \& Yu, 2004; Zhu \& Zhao, 2005; Lu \& Zhu, 2010), whereas for coelacanths, the primitive condition may be exemplified by the rhombic scales of Styloichthys (Zhu \& Yu, 2002; Zhu et al., 2006, 2010; Friedman, 2007). 


\section{CONCLUSION}

The scales of the early coelacanth Miguashaia bureaui from the Frasnian (Upper Devonian) of Miguasha, Québec_(Canada), have been histologically investigated-for the first time, revealing a combination of primitive features for actinistians that allow us to reconstruct the primitive condition of the squamation of coelacanths. The rounded scales devoid of cosmine of Miguashaia can be described as elasmoid scales, in which the superficial layer is ornamented by pointed tubercules and narrow ridges made of dentine capped with enamel (odontodes). At least two generations of superimposed odontodes occur, reminiscent of the primitive condition of stem osteichthyans like Andreolepis or Lophosteus. The middle vascular layer (spongiosa) is well developed and tightly linked to the odontodes. The basal plate (isopedine) consists of a fully mineralized layer of lamellar bone with a twisted plywood-like arrangement of the collagen plies, which display a repetitive rotation pattern every five layers.

The presumably primitive condition of the scales of Miguashaia allows testing evolutionary scenarios for the squamation in coelacanths by comparing Miguashaia with other extinct (e.g. Diplocercides, Diplurus) and extant (Latimeria) actinistians. Despite an important lack of paleohistological comparative material from the scales of extinct coelacanths, 
several evolutionary trends can be inferred from Palaeozoic taxa to Recent: 1) a reduction in number but increase in size of the tubercles and ridges ornamenting the exposed area, 2) an antero-posterior elongation of the scales, 3) the development of larger pulp cavities in the dentine forming the odontodes, and 4) an increase in the relative thickness of the basal plate, coupled with the reduction of the mineralization rate of the isopedine in Latimeria.

Overall, the combination of traits described in Miguashaia do not represent a drastic departure from the histological structure of the scales of other coelacanths like Macropoma (Williamson, 1849), Coelacanthus (Goodrich, 1907), or Undina (Gross, 1935, 1966). Coelacanths are considered to have experienced an early burst of diversification during the Palaeozoic, followed by remarkable morphological conservatism with limited variations until Recent (e.g. Cloutier, 1991a). The scales of Miguashaia already possess the more characteristic features of the actinistian squamation, consistent with this general evolutionary scenario. However, the current uncertainties regarding the position of the putative coelacanth styloichthys and the role of onychodonts as the sister-group of actinistians complicates the reconstruction of the onset of the coelacanth scales prior to the emergence of early eoclacanths forms like Miguashaia or Gavinia. Additional paleohistological data are thus needed from other extinct actinistians and early sarcopterygians. 
These histological features could then be incorporated into future phylogenetic analyses, which would contribute to the unravelling of actinistian interrelationships and continue shedding more light on the evolutionary history of the squamation of coelacanths.

\section{ACKNOWLEDGMENTS}

We would like to warmly thank Severin Morel (MNHN) for the thin-sections, Philippe Loubry (MNHN) for the photographs, and Marc Herbin (MNHN) for granting access to the Latimeria collections under his care. Johanne Kerr (parc national de Miguasha) prepared the loan of specimens and Nathaniel Bertrand Maltais helped with the photographs. Richard Cloutier was funded by NSERC (Discovery Grant).

\section{AUTHORS CONTRIBUTION}

JMF, FJM and GC designed the study. ML provided the fossil material. JMF and FJM acquired the histological cross sections and analysed the data. RC completed the morphological observations. JMF prepared the figures and table, and wrote the text with contributions from FJM and RC. All authors revised the manuscript and approved its final version. 


\section{LITTERATURE CITED}

Andrews, S. M., Long, J., Ahlberg, P. E., Barwick, R. \& Campbell, K. 2006. The structure of the sarcopterygian Onychodus jandemarrai n. sp. from Gogo, Western Australia: with a functional interpretation of the skeleton. Transactions of the Royal Society of Edinburgh, 96 (3): $197-307$.

Amemiya C. T., Powers T. P., Prohaska S. J., Grimwood J., et al. 2010. Complete Hox cluster characterization of the coelacanth provides further evidence for slow evolution of its genome. PNAS, 107: 3622-7.

Amemiya, C. T., Alföldi, J., Lee, A. P., Fan, S., Philippe, H., MacCallum, I. et al. 2013. The African coelacanth genome provides insights into tetrapod evolution. Nature, $496(7445): 311-316$.

Belloti, C. 1857. Descrizione di alcune nuove specie di pesci fossili di Perledo e di altre localitá Lombarde. In Stoppani, A. (ed.). Studii Geologici e Paleontologici sulla Lombardia, pp. 419-438. Milano: Presso Carlo Turati Tipografo Editore.

Bernhauser, A. 1961. Zur Knochen- und Zahnhistologie von Latimeria chalumnae Smith und einiger Fossilformen. Sber. öst. Akad. Wiss., 170: 119-137. 
Bertin L. 1944. Modifications proposées dans la nomenclature des écailles et des nageoires. Bull Soc Zool France. $69: 198-202$.

Botella, H., Blom, H., Dorka, M., Ahlberg, P. E., \& Janvier, P. 2007. Jaws and teeth of the earliest bony fishes. Nature, $448(7153), \quad 583-586$.

Brien P. 1962. Étude de la formation, de la structure des écailles des dipneustes actuels et de leur comparaison avec les autres types d'écailles des Poissons. Ann Mus $R$ Afrique Centrale. 108: 53-129.

Brito, P. M. \& Martill, D. M. 1999. Discovery of a juvenile coelacanth in the Lower Cretaceous, Crato Formation, northeastern Brazil. Cybium, 23 (3), 311-314.

Brito, P. M., Meunier, F. J., Clément, G. \& Geffard-Kuriyama, D. 2010. The histological structure of the calcified lung of the fossil coelacanth Axelrodichthys araripensis (Actinistia: Mawsoniidae). Palaeontology, 53: 1281-1290. Burdak, V. D. 1979. Funktsionai'naya morfologiya cheshuynogo pokrova ryb. Naukova Dumka, Kiev. [Russian with French translation (1986)] .

Burrow, C. 2005. Histological structure of the cancellous bone layer in Bothriolepis canadensis (Antiarchi, Placodermi). Lethaia, $38(3):$ 205-210.

Casane, D. \& Laurenti, P. 2013. Why coelacanths are not 'living fossils': a review of molecular and morphological data. Bioessays, 35: 332-338. 
Castanet, J., Meunier, F., Bergot, C. \& François, Y. 1975. Données préliminaires sur les structures histologiques du squelette de Latimeria chalumnae. I - Dents, écailles, rayons de nageoires. In: Coll. Inter. CNRS, "Problèmes actuels de Paléontologie. Evolution des Vertébrés", Paris, 4-9 Juin 1973, 159-168, 4 Pls.

Cavin, L., Furrer, H., and Obrist, C. 2013. New coelacanth material from the Middle Triassic of eastern Switzerland, and comments on the taxic diversity of actinistans. Swiss Journal of Geosciences, $106(2): 161-177$.

Cavin, L., Mennecart, B., Obrist, C., Costeur, L., \& Furrer, H. 2017. Heterochronic evolution explains novel body shape in a Triassic coelacanth from Switzerland. Scientific reports, 7(1): 13695 .

Chang, M. M., \& Smith, M. M. 1992. Is Youngolepis a porolepiform?. Journal of Vertebrate Paleontology, $12(3)$ : $294-312$.

Chang, M. \& Zhu, M. 1993. A new Middle Devonian osteolepidid from Qujing, Yunnan. Memoirs of the Association of Australasian Palaeontologists, 15: 183-198.

Chevrinais, M., Jacquet, C., \& Cloutier, R. 2017a. Early establishment of vertebrate trophic interactions: food web structure in Middle to Late Devonian fish assemblages with exceptional fossilization. Bulletin of Geosciences, 92(4), 491-510. 
Chevrinais, M., Sire, J. Y., \& Cloutier, R. 2017b. From body scale ontogeny to species ontogeny: Histological and morphological assessment of the Late Devonian acanthodian Triazeugacanthus affinis from Miguasha, Canada. PloS one, $12(4), \mathrm{e} 0174655$.

Chevrinais, M., Johanson, Z., Trinajstic, K., Long, J., Morel, C., Renaud, C. B., \& Cloutier, R. 2018. Evolution of vertebrate postcranial complexity: axial skeleton regionalization and paired appendages in a Devonian jawless fish. Palaeontology, 61(6), 949-961.

Clack, J. A. 1996. Otoliths in fossil coelacanths. Journal of Vertebrate Paleontology, 16(1): 168-171.

Clement, A. M., King, B., Giles, S., Choo, B., Ahlberg, P. E., Young, G. C., \& Long, J. A. 2018. Neurocranial anatomy of an enigmatic Early Devonian fish sheds light on early osteichthyan evolution. Elife, 7, e34349.

Clément, G. 1999. The actinistian (Sarcopterygii) Piveteauia madagascarensis Lehman from the Lower Triassic of Northeastern Madagascar: a redescription on the basis of new material. Journal of Vertebrate Paleontology, 19: 234242 .

Clément, G. 2005. A new coelacanth (Actinistia, Sarcopterygii) from the Jurassic of France, and the question of the closest relative fossil to Latimeria. Journal of Vertebrate Paleontology, 25: 481-491. 
Cloutier, R. 1991a. Patterns, trends, and rates of evolution within the Actinistia. In The biology of Latimeria chalumnae and evolution of coelacanths (pp. 23-58). Springer, Dordrecht.

Cloutier, R. 1991b. Interrelationships of Palaeozoic actinistians: patterns and trends. Early Vertebrates and Related Problems of Evolutionary Biology: Science Press, Beijing, 379-428.

Cloutier, R. 1996. The primitive actinistian Miguashaia bureaui Schultze (Sarcopterygii); pp: 227-247 in H.-P. Schultze \& R. Cloutier (eds.), Devonian Fishes and Plants of Miguasha, Quebec, Canada. Verlag Dr. Friedrich Pfeil, München, Germany.

Cloutier, R. 2010. The fossil record of fish ontogenies: insights into developmental patterns and processes. Seminars in Cell \& Developmental Biology, 21: 400-413.

Cloutier, R. 2013. Great Canadian Lagerstätten 4. The Devonian Miguasha biota (Québec) : UNESCO World Heritage Site and a time capsule in the early history of vertebrates. Geoscience Canada, $40(2)$ : 149-163.

Cloutier, R. \& Ahlberg, P. E. 1996. Morphology, characters, and the interrelationships of basal sarcopterygians; pp: 445-479 in M. L. J. Stiassny, L. R. Parenti, \& G. D. Johnson (eds.), Interrelationships of Fishes. Academic Press, San Diego, USA. 
Cloutier, R. \& Forey, P. L. 1991. Diversity of extinct and living actinistian fishes (Sarcopterygii). Environmental Biology of Fishes, 32: 59-74

Cloutier, R., \& Schultze, H. P. 1996. Porolepiform fishes (Sarcopterygii). pp: 248-270 in H.-P. Schultze \& R. Cloutier (eds.), Devonian Fishes and Plants of Miguasha, Quebec, Canada. Verlag Dr. Friedrich Pfeil, München, Germany .

Cloutier, R., Béchard, I., Charest, F., \& Matton, O. 2009. La contribution des poissons fossiles du parc national de Miguasha à la biologie évolutive du développement. Le naturaliste canadien, $133(3): 84-95$.

Cloutier, R., Loboziak, S., Candilier, A. M., \& Blieck, A. 1996. Biostratigraphy of the Upper Devonian Escuminac Formation, eastern Québec, Canada: A comparative study based on miospores and fishes. Review of Palaeobotany and Palynology, $93(1-4): 191-215$.

Cloutier, R., Proust, J. N., \& Tessier, B. 2011. The Miguasha Fossil-Fish-Lagerstätte: a consequence of the Devonian land-sea interactions. Palaeobiodiversity and Palaeoenvironments, $91(4):$ 293-323.

Cloutier, R., Clement, A. M., Lee, M. S., Noël, R., Béchard, I., Roy, V., \& Long, J. A. 2020. Elpistostege and the origin of the vertebrate hand. Nature, 579(7800): 549-554. Cui, X., Qiao, T., \& Zhu, M. 2019. Scale morphology and squamation pattern of Guiyu oneiros provide new insights 
into early osteichthyan body plan. Scientific reports, $9(1): 1-12$

Cupello, C., Meunier, F. J., Herbin, M., Clément, G. \& Brito, P. M. 2017. Lung anatomy and histology of the extant coelacanth shed light on the loss of air-breathing during deep-water adaptation in actinistians. Royal Society Open Science, 4(3): 161030 .

Denison, R. H. 1968. Early Devonian lungfishes from Wyoming, Utah, and Idaho. Fieldiana (Geol.) 17: 353-413. Dias, E. V. \& Richter M. 2002. On the squamation of Australerpeton cosgriffi Barberena, a temnospondyl amphibian from the Upper Permian of Brazil. Anais da Academia Brasileira de Ciências 74(3): 477-490

Donoghue, P. C. J., Sansom, I. J., \& Downs, J. P. 2006 . Early evolution of vertebrate skeletal tissues and cellular interactions, and the canalization of skeletal development. Journal of Experimental Zoology Part B: Molecular and Developmental Evolution, 306(3): 278-294.

Downs, J. P., \& Donoghue, P. C. 2009. Skeletal histology of Bothriolepis canadensis (Placodermi, Antiarchi) and evolution of the skeleton at the origin of jawed vertebrates. Journal of Morphology, $270(11)$ : 1364-1380. Dutel, H., Maisey, J. G., Schwimmer, D. R., Janvier, P., Herbin, M., \& Clément, G. 2012. The giant Cretaceous coelacanth (Actinistia, Sarcopterygii) Megalocoelacanthus dobiei Schwimmer, Stewart \& Williams, 1994, and its bearing 
on Latimerioidei interrelationships. PLOS One, 7(11), e49911.

Dutel, H., Herbin, M., \& Clément, G. 2015. First occurrence of a mawsoniid coelacanth in the Early Jurassic of Europe. Journal of Vertebrate Paleontology, 35(3), e929581. Eastman, C. R. 1908. Notice of a new coelacanth fish from the Iowa Kinderhook. The Journal of Geology, 16(4): 357-362. Erdmann, M. V., Caldwell, R. L. \& Moosa, M. K. 1998. Indonesian "king of the sea" discovered. Nature, 395: 335. Forey, P.L. 1981. The coelacanth Rhabdoderma in the

Carboniferous of the British Isles. Palaeontology, 24: 203229.

Forey, P. L. 1984. The Coelacanth as a Living Fossil. Pp.166169 in Eldredge N., Stanley S.M. (eds.) Living Fossils. Casebooks in Earth Sciences. Springer, New York. Forey, P. L., Ahlberg, P. E., Luksevics, E. \& Zupins, I. 2000. A new coelacanth from the Middle Devonian of Latvia. Journal of Vertebrate Paleontology, 20: 243-252. Forey, P. L. 1998. History of the Coelacanth Fishes. Chapman \& Hall, London, $419 \mathrm{pp}$. Forey, P. L., \& Young, V. T. 1985. Acanthodian and coelacanth fish from the Dinantian of Foulden, Berwickshire, Scotland. Earth and Environmental Science Transactions of The Royal Society of Edinburgh, $76(1): 53-59$. 
Fragoso, L. G. C., Brito, P., and Yabumoto, Y. 2019. Axelrodichthys araripensis Maisey, 1986 revisited. Historical Biology, $31(10)$ : 1350-1372.

Francillon-Vieillot H., Buffrenil V. De, Castanet J., Géraudie J., Meunier Fj., Sire J-Y., Zylberberg L., \& Ricqlès A. De. 1990. Microstructure and mineralization of vertebrate skeletal tissues. In: Carter, J. G. (ed.), Skeletal Biomineralization: Patterns, Processes and Evolutionary Trends. Vol. I, Van Nostrand, New York, pp. 471-530. Friedman, M. 2007. Styloichthys as the oldest coelacanth: implications for early osteichthyan interrelationships. Journal of Systematic Palaeontology, 5(3): 289-343.

Friedman, M. \& Coates, M. I. 2006. A new recognized fossil coelacanth highlights the early morphological diversification of the clade. Proceedings of the Royal Society $B 273,245-250$.

Geng, B. H., Zhu, M., \& Jin, F. 2009. A revision and phylogenetic analysis of Guizhoucoelacanthus (Sarcopterygii, Actinistia) from the Triassic of China. Vertebrata PalAsiatica, $47(3):$ 165-177.

Gess, R. W., \& Coates, M. I. 2015. Fossil juvenile coelacanths from the Devonian of South Africa shed light on the order of character acquisition in actinistians. Zoological Journal of the Linnean Society, 175(2): 360-383. Gillis, J. A., Dahn, R. D., \& Shubin, N. H. 2009. Shared developmental mechanisms pattern the vertebrate gill arch 
and paired fin skeletons. Proceedings of the National Academy of Sciences, 106(14): 5720-5724.

Giraud, M.M., Castanet, J., Meunier, F.J., Bouligand, Y. 1978a. The fibrous structure of coelacanth scales: a twisted "plywood". Tissue Cell. 10(4):671-686. doi:10.1016/0040-8166(78) 90054-X.

Giraud, M.M., Castanet, J., Meunier, F.J., Bouligand, Y. 1978b. Organisation spatiale de l'isopédine des écailles du coelacanthe (Latimeria chalumnae, Smith). C R Acad Sci. 287: $487-489$.

Goodrich, E. S. 1907. On the scales of fish, living and extinct, and their importance in classification. Proceedings of the Zoological Society of London, 77(4): $751-773$.

Gross, W. 1935. Histologische Studien am Aussenskelett fossiler Agnathen und Fische. Palaeontographica, 83A: 1-60. Gross, W. 1966. Kleine Schuppenkunde. Neues Jahrbuch für Geologie und Paläontologie, Abhandlungen, 125: 29-48. Gross W. 1968. Fragliche Actinopterygier-schuppen aus dem Silur Gotlands. Lethaia. 1(2):184-218. doi:10.1111/j.15023931.1968.tb01736.x.

Gross W. 1969. Lophosteus superbus Pander, ein Teleostome aus dem Silur Oesels. Lethaia, $2(1):$ 15-47. doi:10.1111/let.1969.2.issue-1

Hadiaty, R. K. \& Rachmatika, I. 2003. Morphological study of the scales of Latimeria menadoensis Pouyaud et al., 1999. 
Treubia (A Journal on Zoology of the Indo-Australian Archipelago), 33: 1-11.

Higasa, K., Nikaido, M., Saito, T.L., Yoshimura, J., et al. 2012. Extremely slow rate of evolution in the HoX cluster revealed by comparison between Tanzanian and Indonesian coelacanths. Gene 505: 324-32.

Hureau, J.-C. \& Ozouf, C. 1977. Détermination de l'âge et croissance du coelacanthe Latimeria chalumnae Smith, 1939 (Poisson, Crossoptérygien, Coelacanthidé). Cybium, 1977 (2) : $129-137$.

Jain, S.L. 1974. Indocoelacanthus robustus n. gen., n. sp. (Coelacanthidae, Lower Jurassic), the first fossil coelacanth from India. Journal of Palaeontology, 48: 49-62. Janvier, P. 1996. Early Vertebrates. Clarendon Press, Oxford. $393 \mathrm{pp}$.

Janvier, P., \& Arsenault, M. 2002. Calcification of early vertebrate cartilage. Nature, 417(6889): 609-609. Janvier, P., Arsenault, M., \& Desbiens, S. 2004. Calcified cartilage in the paired fins of the osteostracan Escuminaspis laticeps (Traquair 1880), from the Late Devonian of Miguasha (Québec, Canada), with a consideration of the early evolution of the pectoral fin endoskeleton in vertebrates. Journal of Vertebrate Paleontology, 24(4): $773-779$.

Jarvik, E. 1944. On the dermal bones, sensory canals and pitlines of the skull in Eusthenopteron foordi Whiteaves, with 
some remarks on E. save-soderberghi Jarvik. Kungliga Svenska Vetenskapsakademiens Handlingar, 21: 1-48. Jarvik, E. 1954. On the visceral skeleton in Eusthenopteron with a discussion of the parasphenoid and palatoquadrate in fishes. Kungliga Svenska Vetenskapsakademiens Handlingar, 5: $1-104$

Jarvik, E. 1980. Basic Structure and evolution of Vertebrates. Volume I. 575 pp., London: Academic Press. Jerve A, Qu Q, Sanchez S, Blom H, Ahlberg PE. 2016. Threedimensional paleohistology of the scale and median fin spine of Lophosteus superbus (Pander 1856). PeerJ. 4: e2521. doi:10.7717/peerj.2521.

Jessen, H.L. 1966. Die Crossopterygier des Oberen Plattenkalkes (Devon) der Bergisch- Gladbach-Paffrather Mulde (Rheinisches Schiefergebirge) unter Berücksichtung von amerikanischem und europaischem Onychodus-Material. Arkiv for Zoologi, Stockhohn, 18: 305-389. Jessen, H.L. 1973. Weitere Fischreste aus dem Oberen Plattenkalk der Bergische-Gladbach-Paffrather-Mulde (Oberdevon, Rheinisches Schieferbebirge). Palaeontographica, 143A: 159-187.

Johanson, Z., Long, J. A., Talent, J. A., Janvier, P., \& Warren, J. W. 2006. Oldest coelacanth, from the Early Devonian of Australia. Biology letters, 2(3): 443-446. Johanson, Z., Long, J. A., Talent, J. A., Janvier, P., \& Warren, J. W. 2007. New onychodontiform (Osteichthyes; 
Sarcopterygii) from the Lower Devonian of Victoria, Australia. Journal of Paleontology, 81(5): 1031-1043. Kadarusman, Sugeha, H.Y., Pouyaud, L. et al. 2020. A thirteenmillion-year divergence between two lineages of Indonesian coelacanths. Scientific Reports, 10: 192.

Kner, R. 1866. Die Fische der bituminösen Schiefer von Raibl in Kärnthen. Sitzungsberichte der Akademie der Wissenschaften. Mathematisch-Naturwissenschaftliche Classe, $53: 152-197$.

Lampert, K.P., Fricke, H., Hissmann, K., Schauer, J., et al. 2012. Population divergence in East African coelacanths. Current Biology, 22: R439-40.

Lang, M., Hadzhiev, Y., Siegel, N., Amemiya, C. T., et al. 2010. Conservation of shh cis regulatory architecture of the coelacanth is consistent with its ancestral phylogenetic position. Evodevo, 1: 11 . Laurin, M., Meunier, F. J., Germain, D., \& Lemoine, M. 2007. A microanatomical and histological study of the paired fin skeleton of the Devonian sarcopterygian Eusthenopteron foordi. Journal of Paleontology, 81(1): 143-153. Liu, H.-T. 1964. A new coelacanth from the marine Lower Triassic of N.W. Kwangsi, China. Vertebrata Palasiatica, 8: 211-214. [In Chinese with English summary.]

Liu, G., Yin, G., Luo, Y. et al. 2006. Preliminary examination of fish fossils from Upper Triassic Wayao Member of Falang 
Formation in Guanling of Guizhou. Acta Palaeontologica Sinica, $45(1): 1-20$.

Long, J. A. 1999. A new genus of fossil coelacanth

(Osteichthyes: Coelacanthiformes) from the Middle Devonian of southeastern Australia. Records of the Western Australian Museum, Supplement, 57, 37-53.

Lu, J. \& Zhu, M. 2008. An Early Devonian (Pragian) sarcopterygian from Zhaotong, Yunnan, China. Vertebrata Palasiatica, 46: 161-170.

Lu, J. \& Zhu, M. 2010. An onychodont fish (Osteichthyes, Sarcopterygii) from the Early Devonian of China, and the evolution of the Onychodontiformes. Proceedings of the Royal Society B, 277, 293-299.

Lu, J., Zhu, M., Ahlberg, P. E., Qiao, T., Zhu, Y. A., Zhao, W. \& Jia, L., 2016a. A Devonian predatory fish provides insights into the early evolution of modern sarcopterygians. Science advances, 2 (6): p.e1600154. Lu, J., Giles, S., Friedman, M., Den Blaauween, J. L. \& Zhu, M., 2016b. The oldest actinopterygian highlights the cryptic early history of the hyperdiverse ray-finned fishes. Current Biology, 26 (12): 1602-1608.

Lu, J., Giles, S., Friedman, M. \& Zhu, M. 2017. A new stem sarcopterygian illuminates patterns of character evolution in early bony fishes. Nature communications, 8: 1932. 
Lund, R. \& Lund, W. L. 1984. New genera and species of coelacanths from the Bear Gulch Limestone (lower Carboniferous) of Montana (USA). Geobios 17: 237-244. Lund, R. \& Lund, W. L. 1985. Coelacanths from the Bear Gulch Limestone (Namurian) of Montana and the evolution of the Coelacanthiformes. Bull. Carnegie Mus. Nat. Hist. 25: 1-74. Maisey, J.G. 1986. Coelacanths from the Lower Cretaceous of Brazil. American Museum Novitates, 2866: 1-30. Martin, M. and Wenz, S. 1984. Découverte d'un nouveau Coelacanthide, Garnbergia ommata n. gen., n. sp., dans le Muschelkalk superieur du Baden-Württemberg. Stuttgarter Beitrage zur Naturkunde, Serie B (Geologie und Paläontologie), 105: 1-17.

Meinke, D. K. 1982. A light and scanning electron microscope study on the dermal skeleton of Spermatodus (Pisces: Coelacanthini) and the evolution of the dermal skeleton in coelacanths. Journal of Paleontology, 56: 620-630. Meunier, F. J. 1980. Les relations isopédine-tissu osseux dans le post-temporal et les écailles de la ligne latérale de Latimeria chalumnae (Smith). Zoologica Scripta, 9: 307-317. Meunier, F.J. 1981. 'Twisted plywood' structure and mineralization in the scales of a primitive living fish Amia calva. Tissue Cell. 13(1):165-171. doi:10.1016/0040$8166(81) 90046-X$ 
Meunier, F.J. 1984. Structure et minéralisation des écailles de quelques Osteoglossidae (Ostéichthyens, Téléostéens). Ann SC Nat, Zool. 6: 111-124. 13ème Série.

Meunier, F.J., François, Y. 1980. L'organisation spatiale des fibres de collagène et la minéralisation des écailles des Dipneustes actuels. Bull SoC Zool Fr. 105: 215-226. Meunier, F. J., \& Laurin, M. 2012. A microanatomical and histological study of the fin long bones of the Devonian sarcopterygian Eusthenopteron foordi. Acta Zoologica, $93(1): 88-97$.

Meunier, F. J. \& Zylberberg, L. 1999. The structure of the external layer and of the odontodes of scales in Latimeria chalumnae (Sarcopterygii, Actinistia, Coelacanthidae) revisited using scanning and transmission electron microscopy. In: Séret, B. and Sire, J.-Y. (eds.), Proc. 5th Indo-Pacific Fish Conf., Nouméa, 1997, Soc. Fr. Ichtyol., Paris, pp. 109-116.

Meunier, F. J., Cupello, C.\& Clément, G. 2019. The skeleton and the mineralized tissues of the living coelacanths. Bulletin of Kitakyushu Museum of Natural History and Human History, 17, 37-48. Meunier, F. J., Erdmann, M. V., Fermon, Y. \& Caldwell, R. L. 2008. Can the comparative study of the morphology and histology of the scales of Latimeria menadoensis and L. chalumnae (Sarcopterygii: Actinistia, Coelacanthidae) bring new insight on the taxonomy and the biogeography of recent 
coelacanthids? Pp. 351-360 in Cavin, L., Longbottom, A. \& Richter, M. (eds) Fishes and the Break-up of Pangaea. Geological Society, London, Special Publications, 295. Meunier, F. J., Otero, O., \& Laurin, M. 2018. Histological study of the jaw teeth in the Devonian actinopterygian $\dagger$ Cheirolepis canadensis (Whiteaves). Cybium, $42(1)$ : 67-74. Miller, W. A. 1979. Observations on the structure of mineralized tissue of the coelacanth, including scales and their associate odontodes. Occasional Papers of the Californian Academy of Sciences, 134: 68-78.

Millot, J. \& Anthony, J. 1958. Anatomie de Latimeria chalumnae. T. 1. Squelette, muscles et formations de soutien. CNRS Edr., Paris. 122 pp., 80 pls. Millot, J., Anthony, J. \& Robineau, D. 1978. Anatomie de Latimeria chalumnae. T. 3. Appareil digestif, téguments, écailles. CNRS Edr., Paris. pp. 7-28, 135-139. Mondéjar-Fernández, J. 2018. On cosmine: its origins, biology and implications for sarcopterygian interrelationships. Cybium, 42 (1): 41-65. Mondéjar-Fernández, J. 2020. A new onychodont (Osteichthyes; Sarcopterygii) from the Middle Devonian of Morocco and its bearing on early osteichthyan evolution. Journal of Systematic Palaeontology, $18(7):$ 573-606. Mondéjar-Fernández, J. \& Clément G. 2012. Squamation and scale microstructure evolution in the Porolepiformes (Sarcopterygii, Dipnomorpha) based on Heimenia ensis from 
the Devonian of Spitsbergen. Journal of Vertebrate Paleontology 32 (2): 267-284.

Mondéjar Fernández, J., \& Meunier, F. J. 2020. New histological information on Holoptychius Agassiz, 1839 (Sarcopterygii, Porolepiformes) provides insights into the palaeoecological implications and evolution of the basal plate of the scales of osteichthyans. Historical Biology, $1-13$.

Moy-Thomas, J.A. 1937. The Carboniferous coelacanth fishes of Great Britain and Ireland. Proceedings of the Zoological Society of London, B, 3: 383-415.

Münster, G. von. 1834. Mittheilungen an Professor Bronn gerichtet. Neues Jahrbuch for Mineralogie Geognosie, Geologie und Petrefakten-Kunde, 1834: 538-542.

Münster, G. von. 1842. Beitrag zur Kenntnis einiger neuen seltenen Versteinerungen aus dem lithographischen Schiefem in Baiem. Neues Jahrbuch for Mineralogie Geognosie, Geologie und Petrefakten-Kunde, 1842: 35-46.

Nulens R, Scott L, Herbin M. 2011 An updated inventory of all known specimens of the coelacanth Latimeria spp. Smithiana, $3: 1-52$.

Organ, C., Struble, M., Canoville, A., de Buffrénil, V., \& Laurin, M. 2016. Macroevolution of genome size in sarcopterygians during the water-land transition. Comptes rendus Palévol, $15(1-2)$ : 65-73. 
Ørvig, T. 1957. Remarks on the vertebrate fauna of the lower Upper Devonian of Escuminac Bay, P.Q. Canada, with special reference to the porolepiform crossopterygians. Arkiv för Zoologi, $10(6), 367-426$.

Ørvig, T. 1969. Vertebrates from the Wood Bay Group and the position of the Emsian-Eifelian boundary in the Devonian of Vestspitsbergen. Lethaia, 2, 272-328.

Ørvig, T. 1977. A survey of odontodes ('dermal teeth') from developmental, structural, functional, and phyletic points of view; pp: 53-75 in S. M. Andrews, R. S. Miles \& A. D. Walker (eds.), Problems in Vertebrate Evolution, Linnean Society Series 4. Academic Press, London, UK.

Pearson, D. M. 1982. Primitive bony fishes, with especial reference to Cheirolepis and palaeonisciform actinopterygians. Zoological Journal of the Linnean Society, $74: 35-67$.

Pouyaud, L., Wirjoatmodio, S., Rachmatika, L. Tjakrawidjaja, A., Hadiaty, R. K. \& Hadie, W. 1999. Une nouvelle espèce de coelacanthe, preuves génétiques et morphologiques. Comptes Rendus de I'Académie des Sciences, 322: 261-267.

Qu, Q., Zhu M. \& Wang, W. 2013. Scales and dermal skeletal histology of an early bony fish Psarolepis romeri and their bearing on the evolution of rhombic scales and hard tissues. PLOS ONE, 8, e61485.

Qu, Q., Sanchez, S., Zhu, M., Blom, H. \& Ahlberg, P. 2016. The origin of novel features by changes in developmental 
mechanisms: ontogeny and three-dimensional microanatomy of polyodontode scales of two early osteichthyans. Biological Reviews, 92 (2), 1189-1212.

Renesto, S., \& Stockar, R. 2018. First record of a coelacanth fish from the Middle Triassic Meride Limestone of Monte San Giorgio (Canton Ticino, Switzerland). Rivista Italiana D Paleontologia E Stratigrafia, 124(3), 639-653.

Roux, G. H. 1942. The microscopic anatomy of the Latimeria scale. South African Journal of Medical Sciences, 7: 1-18. Saint-Seine, P. de. 1949. Les poissons des calcaires lithographiques de Cerin (Ain). Nouvelles Archives du Muséum d'Histoire Naturelle de Lyon, 2: 1-357. Saint-Seine, P. de. 1955. Poissons fossiles de l''étage de Stanleyville. I. La faune des argilites et schistes bitumineux. Annales du Musée Royal du Congo Beige Tervueen, Sciences Géologiques, 14: 1-126.

Schaeffer, B. 1941. A revision of Coelacanthus newarki and notes on the evolution of the girdles and basal plates of the median fins in the coelacanthini. American Museum Novitates, 1110: 1-17.

Schaeffer, B. 1948. A study of Diplurus Iongicaudatus with notes on the body form and locomotion of the coelacanthini. American Museum Novitates, 1378: 1-32.

Schaeffer, B. 1952. The Triassic coelacanth Diplurus, with observations on the evolution of the Coelacanthini. Bull. Am. Mus. Nat. Hist., 99: 25-78. 
Schaeffer, B. 1962. A coelacanth fish from the Upper Devonian of Ohio. Sci. Publ. Cleveland Mus. Nat. Hist., 1: 1-14.

Schaeffer, B. 1967. Late Triassic fishes from the western United States. Bulletin of the American Museum of Natural History, 135: 285-342.

Schaeffer, B. 1977. The dermal skeleton in fishes. In: Problems in Vertebrate Evolution (Andrews S.M., Miles R.S. \& Walker A.D., eds.), pp. 25-51. Linnean Society Series 4. Academic Press, London, UK.

Schönbörner, A.A., Meunier, F.J., Castanet J. 1981. The fine structure of calcified Mandl's corpuscles in teleost fish scales. Tissue and Cell, 13(3): 589-597. doi:10.1016/0040$8166(81) 90029-X$

Schultze, H.-P. 1968. Palaeoniscoidea-schuppen aus dem Unterdevon Australiens und Kansas und aus dem Mitteldevon Spitzbergens. Bulletin of the British Museum (Natural History), Geology 16: 343-368.

Schultze, H.-P. 1969. Die Faltenzähne der Rhipidistiden Crossopterygier, der Tetrapoden und der ActinopterygierGattung Lepisosteus nebst einer Beschreibung der Zahnstruktur von Onychodus (Strunifformer Crossopterygier). Palaeontol Ital. New Ser. 35 (65): 63-137.

Schultze, H.-P. 1972. Early growth stages in coelacanth fishes. Nature New Biololgy 236: 90-91. Schultze, H.-P. 1973. Crossopterygier mit heterozerker Schwanzflosse aus dem Oberdevon Kanadas, nebst einer 
Beschreibung von Onychodontida-resten aus dem Mitteldevon Spaniens und aus dem Karbon der USA. Palaeontographica Abteilung (A), 143: 188-208.

Schultze H.-P. 1977. Ausgangsform und Entwicklung der rhombischen Schuppen der Osteichthyes (Pisces). Paläontologische Zeitschrift, 51: 152-168.

Schultze, H.-P. 1980. Eier legende und lebend gebärende Quastenflosser. Natur und Museum 110: 101-108.

Schultze H.-P. 2015. Scales, enamel, cosmine, ganoine, and early osteichthyans. C R Palevol. $15(1-2)$ : 83-102. doi:10.1016/j.crpv.2015.04.001

Schultze, H.-P. 2018. Hard tissues in fish evolution: history and current issues. Cybium, 42(1): 29-39.

Schweizer, R. 1966. Ein Coelacanthide aus dem Oberen Muschelkalk Gottingens. Neues Jahrbuch für Geologie und Paläontologie, Abhandlungen, 125: 216-226.

Sire J-Y, Akimenko M-A. 2004. Scale development in fish: a review, with description of sonic hedgehog (shh) expression in the zebrafish (Danio rerio). Int J Dev Biol, 48:233-47. Sire, J. Y., \& Huysseune, A. N. N. 2003. Formation of dermal skeletal and dental tissues in fish: a comparative and evolutionary approach. Biological Reviews, $78(2)$ : 219-249. Sire J.Y., Donoghue P.C. \& Vickaryous M.K., 2009. Origin and evolution of the integumentary skeleton in non-tetrapod vertebrates. Journal of Anatomy, 214: 409-440. 
Smith, J. L. B. 1939. A living fish of Mesozoic type. Nature, $143: 455-456$.

Smith, M. M. 1977. The microstructure of the dentition and dermal ornament of three dipnoans from the Devonian of Western Australia: a contribution towards dipnoan interrelations. and morphogenesis. growth and adaptation of the skeletal tissues. Philosophical Transactions of the Royal Society of London B, 281: 2972 .

Smith, M. M. 1979. Scanning electron microscopy of odontodes in the scales of coelacanth embryo, Latimeria chalumnae Smith. Archives of Oral Biology, 24: 179-183.

Smith, M. M., Hobdell, M. H. \& Miller, W. A. 1972. The structure of the scales of Latimeria chalumnae. Journal of Zoology, London, 167: 501-509.

Smith, M., Smithson, T. R., \& Campbell, K. S. W. 1987. The relationships of Uronemus: a Carboniferous dipnoan with highly modified tooth plates. Philosophical Transactions of the Royal Society of London. B, Biological Sciences, $317(1185): 299-327$.

Stensiö, E.A. 1921. Triassic Fishes from Spitzbergen, Part 1. xxviii + 307 pp., Vienna: Adolf Holzhausen.

Stensiö, E. A. 1922. Über zwei Coelacanthiden aus dem Oberdevon von Wildungen. Paläontologische Zeitschrift, 4(23), 167-210.

Stensiö, E. A. 1932. Triassic fishes from East Greenland. Meddelelser om Groenland, 83: 1-305. 
Stensiö, E. A. 1937. On the Devonian coelacanthids of Germany with special reference to the dermal skeleton. Kungliga Svenska Vetenskapsakademiens Handlingar, Series 3, 16, 156.

Thomson, K. S. 1972. An attempt to reconstruct evolutionary changes in the cellular DNA content of lungfish. Journal of Experimental Zoology, 182: 363-372.

Tong, J., Zhou, X., Erwin, D. H., Zuo, J., and Zhao, L. 2006. Fossil fishes from the Lower Triassic of Majiashan, Chaohu, Anhui Province, China. Journal of Paleontology, 80(1): 146161.

Wang N-Z, \& Dong -Z-Z. 1989. Discovery of Late Silurian

microfossils of Agnatha and fishes from Yunnan, China. Acta Paleontologica Sinica. 28: 192-206.

Wang, N. and Liu, H. 1981. Coelacanth fishes from the marine Permian of Zhejiang, South China. Vertebrata Palasiatica, 19: 305-312, 4 figs. [In Chinese with English summary.] Watson, D. M. S. 1927. The reproduction of the coelacanth fish, Undina. Proceedings of the Zoological Society of London, 97 (2): 453-457).

Wen, W., Zhang, Q. Y., Hu, S. X., Benton, M. J., Zhou, C. Y., et al. 2013. Coelacanths from the Middle Triassic Luoping Biota, Yunnan, South China, with the earliest evidence of ovoviviparity. Acta Palaeontologica Polonica, 58(1): 175193. 
Wendruff, A. J., \& Wilson, M. V. 2012. A fork-tailed coelacanth, Rebellatrix divaricerca, gen. et sp. nov. (Actinistia, Rebellatricidae, fam. nov.), from the Lower Triassic of Western Canada. Journal of Vertebrate Paleontology, $32(3): 499-511$.

Westoll, T. S. 1938. Ancestry of the tetrapods. Nature, $141(3559): 127-128$.

Westoll, T. S. 1939. On Spermatodus pustulosus Cope, a coelacanth from the "Permian" of Texas. American Museum Novitates, 1017: 1-23.

Williamson, W. C. 1849. XXIII. On the microscopic structure of the scales and dermal teeth of some Ganoid and Placoid Fish. Philosophical Transactions of the Royal Society of London, 139: 435-475.

Woodward, A.S. 1916. The Fossil Fishes of the English Wealden and Purbeck Formations. Part 1. pp. 1-48, London: Palaeontographical Society.

Yabumoto, Y. 2002. A new coelacanth from the Early Cretaceous of Brazil (Sarcopterygii, Actinistia). Paleontological Research, 6(4): 343-350.

Yabumoto, Y. 2008. A new Mesozoic coelacanth from Brazil (Sarcopterygii, Actinistia). Paleontological Research, $12(4): 329-343$.

Yabumoto, Y., \& Brito, P. M. 2016. A New Triassic Coelacanth, Whiteia oishii (Sarcopterygii, Actinistia) from West Timor, Indonesia. Paleontological Research, 20(3), 233-246. 
Yabumoto, Y., Brito, P. M., Iwata, M., \& Abe, Y. 2019. A new Triassic coelacanth, Whiteia uyenoteruyai (Sarcopterygii, Actinistia) from Madagascar and paleobiogeography of the family Whiteiidae. Bulletin of Kitakyushu Museum of Natural History and Human History Series A (Natural History), 17, $15-27$

Zhu, M. \& Yu, X. 2002. A primitive fish close to the common ancestor of tetrapods and lungfish. Nature, 418, 767-770. Zhu, M. \& Yu, X. 2004. Lower jaw character transitions among major sarcopteygian groups-a survey based on new materials from Yunnan, China. Pp. 271-286 in G. Arratia, M. V. H. Wilson \& R. Cloutier (eds) Recent advances in the origin and early radiation of vertebrates. Verlag Dr. Friedrich Pfeil, Munich.

Zhu, M., \& Zhao, W. 2005. An onychodont-like sarcopterygian fish from the Middle Devonian of Yunnan, southwestern China. Journal of Vertebrate Paleontology, 25 (3, Supplement), 134 A.

Zhu, M., Yu, X. \& Ahlberg, P. E. 2001. A primitive sarcopterygian fish with an eyestalk. Nature, 410, 81-84. Zhu, M., Yu, X. \& Janvier, P. 1999. A primitive fossil fish sheds light on the origin of bony fishes. Nature, 397, 607610.

Zhu, M., Yu, X., Wang, W., Zhao, W. \& Jia, L. 2006. A primitive fish provides key characters bearing on deep osteichthyan phylogeny. Nature, 441, 77-80. 
Zhu, M., Zhao, W., Jia, L. Lu, J., Qiao, J. \& Q. Qu. 2009. The oldest articulated osteichthyan reveals mosaic gnathostome characters. Nature, 458, 469-474.

Zhu, M., Wang W. \& Yu, X. 2010. Meemannia eos, a basal sarcopterygian fish from the Lower Devonian of China expanded description and significance; pp: 199-214 in D. K. Elliot, J. G. Maisey, X. Yu \& D. Miao (eds.), Morphology, Phylogeny and Paleobiogeography of Fossil Fishes. Verlag Dr. Friedrich Pfeil, München, Germany. Zhu, M., Yu, X., Lu, J., Qiao, T., Zhao, W. \& Jia, L. 2012. Earliest known coelacanth skull extends the range of anatomically modern coelacanths to the Early Devonian. Nature Communications, 3: 772 .

Zylberberg, L., Meunier, F. J., \& Laurin, M. 2010. A microanatomical and histological study of the postcranial dermal skeleton in the Devonian sarcopterygian Eusthenopteron foordi. Acta Palaeontologica Polonica, $55(3): 459-470$.

Zylberberg, L., Géraudie, J., Meunier, F.J., Sire, J.Y. 1992. Biomineralization in the integumental skeleton of the living lower Vertebrates. In: Hall BK, editor. Bone, Vol. 4. Boca Raton, FL: CRC Press; p. 171-224. Zylberberg, L., Meunier, F. J., \& Laurin, M. 2015. A microanatomical and histological study of the postcranial dermal skeleton of the Devonian actinopterygian Cheirolepis canadensis. Acta Palaeontologica Polonica, 61(2): 363-376. 


\section{TABLES}

Table 1. List of extinct coelacanths for which the squamation has been studied and figured.

\begin{tabular}{|c|c|c|c|c|c|c|c|c|c|c|}
\hline \multirow[b]{3}{*}{ Genus } & \multirow[b]{3}{*}{$\begin{array}{c}\text { Speci } \\
\text { es }\end{array}$} & \multicolumn{4}{|c|}{ Scale Morphology } & \multicolumn{4}{|c|}{ Scale Histology } & \multirow{3}{*}{$\begin{array}{l}\text { Ref } \\
\text { ere } \\
\text { nce }\end{array}$} \\
\hline & & \multirow{2}{*}{ Shap } & \multicolumn{2}{|c|}{$\begin{array}{c}\text { External } \\
\text { surface }\end{array}$} & \multirow{2}{*}{$\begin{array}{c}\text { Int } \\
\text { ern } \\
\text { al } \\
\text { sur } \\
\text { fac } \\
\text { e }\end{array}$} & \multirow[b]{2}{*}{$\begin{array}{c}\text { Ename } \\
\text { l/ena } \\
\text { meloi } \\
\text { d }\end{array}$} & \multirow[b]{2}{*}{$\begin{array}{c}\text { Den } \\
\text { tin } \\
e\end{array}$} & \multirow[b]{2}{*}{$\begin{array}{c}\text { Vas } \\
\text { cul } \\
\text { ar } \\
\text { bon } \\
\text { e }\end{array}$} & \multirow[b]{2}{*}{$\begin{array}{c}\text { Lam } \\
\text { ell } \\
\text { ar } \\
\text { bon } \\
\text { e }\end{array}$} & \\
\hline & & & $\begin{array}{c}\text { Expo } \\
\text { sed } \\
\text { area }\end{array}$ & $\begin{array}{l}\text { Ove } \\
\text { rla } \\
\text { ppe } \\
\text { d } \\
\text { are } \\
\text { a }\end{array}$ & & & & & & \\
\hline $\begin{array}{l}\text { Alleny } \\
\text { pterus }\end{array}$ & $\begin{array}{c}\text { A. } \\
\text { monta } \\
\text { nus }\end{array}$ & $\begin{array}{l}\text { spin } \\
\text { dle- } \\
\text { shap } \\
\text { ed } \\
\text { (ven } \\
\text { trom } \\
\text { edia } \\
\text { n } \\
\text { scal } \\
\text { es) }\end{array}$ & $\begin{array}{c}\text { unor } \\
\text { name } \\
\text { nted } \\
\text { ? }\end{array}$ & & & - & - & - & - & $\begin{array}{c}\text { Lun } \\
d \& \\
\text { Lun } \\
\text { d, } \\
198 \\
5\end{array}$ \\
\hline Axelia & $\begin{array}{c}\text { A. } \\
\text { robus } \\
\text { ta }\end{array}$ & $\begin{array}{c}\text { ovat } \\
e\end{array}$ & $\begin{array}{c}\text { stou } \\
t \\
\text { ridg } \\
\text { es } \\
\text { and } \\
\text { tube } \\
\text { rcle } \\
\text { s }\end{array}$ & - & - & 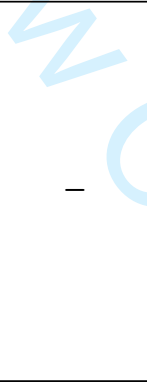 & & - & - & $\begin{array}{c}\text { Ste } \\
\text { nsi } \\
\ddot{0}, \\
192 \\
1\end{array}$ \\
\hline $\begin{array}{c}\text { Axelro } \\
\text { dichth } \\
y s\end{array}$ & $\begin{array}{c}A . \\
\operatorname{arari} \\
\text { pensi } \\
\text { S }\end{array}$ & $\begin{array}{c}\text { ovat } \\
e\end{array}$ & $\begin{array}{c}\text { long } \\
\text { cent } \\
\text { ral } \\
\text { ridg } \\
\text { e } \\
\text { and } \\
\text { narr } \\
\text { ow } \\
\text { late } \\
\text { ral } \\
\text { ridg } \\
\text { es }\end{array}$ & - & - & - & - & - & - & $\begin{array}{c}\text { Mai } \\
\text { sey } \\
\prime \\
198 \\
6 ; \\
\text { Fra } \\
\text { gos } \\
\text { o } \\
\text { et } \\
\text { al. } \\
\prime \\
201 \\
9\end{array}$ \\
\hline
\end{tabular}




\begin{tabular}{|c|c|c|c|c|c|c|c|c|c|c|}
\hline $\begin{array}{l}\text { Carido } \\
\text { suctor }\end{array}$ & $\begin{array}{c}\text { C. } \\
\text { popul } \\
\text { osum }\end{array}$ & $\begin{array}{c}\text { ovat } \\
e\end{array}$ & $\begin{array}{l}\text { narr } \\
\text { ow } \\
\text { ridg } \\
\text { es }\end{array}$ & - & - & - & - & - & - & $\begin{array}{c}\text { Lun } \\
d \& \\
\text { Lun } \\
\text { d, } \\
198 \\
5 ; \\
\text { For } \\
\text { ey, } \\
199 \\
8\end{array}$ \\
\hline $\begin{array}{c}\text { Chagri } \\
\text { nia }\end{array}$ & $\begin{array}{c}C . \\
\text { enodi } \\
S\end{array}$ & oval & $\begin{array}{l}\text { unor } \\
\text { name } \\
\text { nted }\end{array}$ & - & - & $\begin{array}{c}\text { absen } \\
t ?\end{array}$ & $\begin{array}{c}\text { abs } \\
\text { ent } \\
?\end{array}$ & $\begin{array}{c}\text { pre } \\
\text { sen } \\
t\end{array}$ & - & $\begin{array}{c}\text { Sch } \\
\text { aef } \\
\text { fer } \\
{ }^{\prime} \\
196 \\
2\end{array}$ \\
\hline $\begin{array}{c}\text { Changx } \\
\text { ingia }\end{array}$ & $\begin{array}{c}C . \\
\text { aspra } \\
\text { talis }\end{array}$ & oval & $\begin{array}{c}\text { elon } \\
\text { gate } \\
\text { ridg } \\
\text { es }\end{array}$ & - & - & - & - & - & - & $\begin{array}{c}\text { Wan } \\
\text { g\& } \\
\text { Liu } \\
\prime \\
198 \\
1\end{array}$ \\
\hline $\begin{array}{c}\text { Chaohu } \\
\text { ichthy } \\
\text { s }\end{array}$ & $\begin{array}{c}C . \\
\text { majia } \\
\text { shane } \\
\text { nsis }\end{array}$ & $\begin{array}{c}\text { ovat } \\
e\end{array}$ & $\begin{array}{l}\text { narr } \\
\text { ow } \\
\text { ridg } \\
\text { es }\end{array}$ & - & & $\begin{array}{c}\text { prese } \\
\text { nt? }\end{array}$ & - & - & - & $\begin{array}{c}\text { Ton } \\
9 \\
\text { et } \\
\text { al. } \\
2^{\prime} 00 \\
6\end{array}$ \\
\hline $\begin{array}{c}\text { Chinle } \\
a\end{array}$ & $\begin{array}{c}C . \\
\text { soren } \\
\text { seni }\end{array}$ & oval & $\begin{array}{l}\text { narr } \\
\text { ow } \\
\text { ridg } \\
\text { es }\end{array}$ & $\begin{array}{c}\text { con } \\
\text { cen } \\
\text { tri } \\
\text { c } \\
\text { gro } \\
\text { wth } \\
\text { rin } \\
\text { gs }\end{array}$ & - & - & - & - & - & $\begin{array}{c}\text { Sch } \\
\text { aef } \\
\text { fer } \\
\text { ' } \\
196 \\
7\end{array}$ \\
\hline \multirow{2}{*}{$\begin{array}{c}\text { Coccod } \\
\text { erma }\end{array}$} & $\begin{array}{c}C . \\
\text { subst } \\
\text { riola } \\
\text { tum }\end{array}$ & \multirow{2}{*}{ oval } & $\begin{array}{l}\text { smal } \\
1 \\
\text { ridg } \\
\text { es }\end{array}$ & - & - & - & - & - & - & $\begin{array}{c}\text { For } \\
\text { ey, } \\
199 \\
8\end{array}$ \\
\hline & $\begin{array}{c}\text { C. } \\
\text { suevi } \\
\text { cum }\end{array}$ & & $\begin{array}{l}\text { narr } \\
\text { ow } \\
\text { ridg } \\
\text { es }\end{array}$ & - & - & - & - & - & - & $\begin{array}{c}\text { For } \\
\text { ey, } \\
199 \\
8\end{array}$ \\
\hline $\begin{array}{l}\text { Coelac } \\
\text { anthus }\end{array}$ & $\begin{array}{c}\text { C. } \\
\text { granu } \\
\text { latus }\end{array}$ & oval & $\begin{array}{c}\text { tube } \\
\text { rcle } \\
\text { s }\end{array}$ & - & - & $\begin{array}{c}\text { absen } \\
t ?\end{array}$ & $\begin{array}{c}\text { abs } \\
\text { ent } \\
? \\
\text { lar } \\
\text { ge } \\
\text { pul }\end{array}$ & $\begin{array}{l}\text { ost } \\
\text { eon } \\
\text { al } \\
\text { rem } \\
\text { ode }\end{array}$ & $\begin{array}{c}\text { ful } \\
\text { ly } \\
\text { min } \\
\text { era } \\
\text { lis } \\
\text { ed }\end{array}$ & $\begin{array}{c}\text { Goo } \\
\text { dri } \\
\text { ch, } \\
190 \\
7 ; \\
\text { For }\end{array}$ \\
\hline
\end{tabular}




\begin{tabular}{|c|c|c|c|c|c|c|c|c|c|c|}
\hline & & & & & & & $\begin{array}{c}\mathrm{p} \\
\mathrm{cav} \\
\text { iti } \\
\text { es? }\end{array}$ & $\begin{array}{c}11 \mathrm{i} \\
\mathrm{ng}\end{array}$ & & $\begin{array}{c}\text { ey } \\
199 \\
8\end{array}$ \\
\hline & $\begin{array}{c}C . \\
\text { lunze } \\
\text { nsis }\end{array}$ & & $\begin{array}{l}\text { elon } \\
\text { gate } \\
\text { ridg } \\
\text { es }\end{array}$ & - & - & - & - & - & - & $\begin{array}{l}\text { For } \\
\text { ey, } \\
199 \\
8\end{array}$ \\
\hline \multirow{3}{*}{$\begin{array}{c}\text { Diploc } \\
\text { ercide } \\
\qquad\end{array}$} & $\begin{array}{c}D . \\
\text { heili } \\
\text { genst } \\
\text { ocken } \\
\text { sis }\end{array}$ & \multirow{3}{*}{$\begin{array}{l}\text { subc } \\
\text { ircu } \\
\text { lar }\end{array}$} & $\begin{array}{l}\text { elon } \\
\text { gate } \\
\text { ridg } \\
\text { es }\end{array}$ & $\begin{array}{l}\text { thi } \\
\text { n } \\
\text { rad } \\
\text { ial } \\
\text { rid } \\
\text { ges }\end{array}$ & - & - & - & - & - & $\begin{array}{c}\text { Jes } \\
\text { sen } \\
\prime \\
196 \\
6, \\
197 \\
3\end{array}$ \\
\hline & $\begin{array}{c}D . \\
j a e c k \\
e l i\end{array}$ & & $\begin{array}{c}\text { shor } \\
t \\
\text { ridg } \\
\text { es } \\
\text { and } \\
\text { spoo } \\
\text { n- } \\
\text { shap } \\
\text { ed } \\
\text { tube } \\
\text { rcle } \\
\text { s }\end{array}$ & $\begin{array}{l}\text { thi } \\
\text { n } \\
\text { rad } \\
\text { ial } \\
\text { rid } \\
\text { ges }\end{array}$ & - & $\begin{array}{c}\text { prese } \\
\text { nt? }\end{array}$ & $\begin{array}{l}\text { pre } \\
\text { sen } \\
t ?\end{array}$ & - & - & $\begin{array}{c}\text { Ste } \\
\text { nsi } \\
\ddot{0}, \\
192 \\
2, \\
\text { Gro } \\
\text { ss, } \\
193 \\
5, \\
196 \\
6\end{array}$ \\
\hline & $\begin{array}{c}D . \\
\text { kayse } \\
r i\end{array}$ & & $\begin{array}{l}\text { elon } \\
\text { gate } \\
\text { ridg } \\
\text { es }\end{array}$ & $\begin{array}{l}\text { thi } \\
\mathrm{n} \\
\text { rad } \\
\text { ial } \\
\text { rid } \\
\text { ges }\end{array}$ & - & & & - & - & $\begin{array}{c}\text { Ste } \\
\text { nsi } \\
\text { ö, } \\
193 \\
7, \\
\text { For } \\
\text { ey, } \\
199 \\
8\end{array}$ \\
\hline \multirow[t]{2}{*}{$\begin{array}{c}\text { Diplur } \\
\text { us }\end{array}$} & $\begin{array}{c}D . \\
\text { newar } \\
k i\end{array}$ & \multirow[t]{2}{*}{$\begin{array}{c}\text { ovat } \\
e\end{array}$} & $\begin{array}{l}\text { elon } \\
\text { gate } \\
\text { stou } \\
t \\
\text { ridg } \\
\text { es }\end{array}$ & - & - & $\begin{array}{c}\text { prese } \\
\text { nt? }\end{array}$ & $\begin{array}{l}\text { pre } \\
\text { sen } \\
t ?\end{array}$ & $\begin{array}{l}\text { pre } \\
\text { sen } \\
\text { t? }\end{array}$ & $\begin{array}{l}\text { ful } \\
\text { ly } \\
\text { min } \\
\text { era } \\
\text { lis } \\
\text { ed? }\end{array}$ & $\begin{array}{c}\text { Sch } \\
\text { aef } \\
\text { fer } \\
\text { ' } \\
195 \\
2 ; \\
\text { For } \\
\text { ey, } \\
199 \\
8\end{array}$ \\
\hline & $\begin{array}{c}D . \\
\text { longi } \\
\text { cauda } \\
\text { tus }\end{array}$ & & $\begin{array}{l}\text { elon } \\
\text { gate } \\
\text { narr } \\
\text { ow }\end{array}$ & $\begin{array}{l}\text { thi } \\
\text { n } \\
\text { rad } \\
\text { ial }\end{array}$ & - & $\begin{array}{c}\text { prese } \\
\text { nt? }\end{array}$ & - & - & - & $\begin{array}{l}\text { Sch } \\
\text { aef } \\
\text { fer } \\
,\end{array}$ \\
\hline
\end{tabular}




\begin{tabular}{|c|c|c|c|c|c|c|c|c|c|c|}
\hline & & & $\begin{array}{c}\text { ridg } \\
\text { es }\end{array}$ & $\begin{array}{l}\text { rid } \\
\text { ges }\end{array}$ & & & & & & $\begin{array}{c}194 \\
8\end{array}$ \\
\hline $\begin{array}{c}\text { Foreyi } \\
a\end{array}$ & $\begin{array}{c}F . \\
\operatorname{maxku} \\
h n i\end{array}$ & oval & $\begin{array}{l}\text { stou } \\
t \\
\text { ridg } \\
\text { es } \\
\text { or } \\
\text { tube } \\
\text { rcle } \\
\text { s } \\
\text { and } \\
\text { fine } \\
\text { stri } \\
\text { atio } \\
\text { ns } \\
\text { post } \\
\text { erio } \\
\text { rly }\end{array}$ & $\begin{array}{l}\text { con } \\
\text { cen } \\
\text { tri } \\
\text { c } \\
\text { gro } \\
\text { wth } \\
\text { rin } \\
\text { gs }\end{array}$ & $\begin{array}{l}\text { smo } \\
\text { oth } \\
{ }^{\prime} \\
\text { dro } \\
\text { p- } \\
\text { sha } \\
\text { ped } \\
\text { bos } \\
\text { s }\end{array}$ & - & - & - & - & $\begin{array}{c}\text { Cav } \\
\text { in } \\
\text { et } \\
\text { al. } \\
2^{\prime} \\
201 \\
7\end{array}$ \\
\hline $\begin{array}{c}\text { Gavini } \\
a\end{array}$ & $\begin{array}{c}G . \\
\text { syntr } \\
\text { ips }\end{array}$ & $\begin{array}{l}\text { subc } \\
\text { ircu } \\
\text { lar }\end{array}$ & $\begin{array}{l}\text { wavy } \\
\text { ridg } \\
\text { es } \\
\text { surr } \\
\text { ound } \\
\text { ed } \\
\text { by } \\
\text { fine } \\
\text { r } \\
\text { ridg } \\
\text { es } \\
\text { and } \\
\text { spoo } \\
\text { n- } \\
\text { shap } \\
\text { ed } \\
\text { tube } \\
\text { rcle } \\
\text { s }\end{array}$ & - & - & - & - & - & - & $\begin{array}{c}\text { Lon } \\
9 \text {, } \\
199 \\
9\end{array}$ \\
\hline $\begin{array}{c}\text { Garnbe } \\
\text { rgia }\end{array}$ & $\underset{\substack{G . \\
\text { ommat }}}{c}$ & oval & $\begin{array}{l}\text { narr } \\
\text { ow } \\
\text { ridg } \\
\text { es }\end{array}$ & - & - & - & 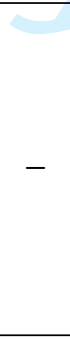 & - & - & $\begin{array}{c}\text { Mar } \\
\text { tin } \\
\& \\
\text { Wen } \\
\text { z, } \\
198 \\
4 \\
\end{array}$ \\
\hline $\begin{array}{l}\text { Graphi } \\
\text { uricht } \\
\text { hys }\end{array}$ & $\begin{array}{c}G . \\
\text { callo } \\
\text { pteru } \\
\text { s }\end{array}$ & oval & $\begin{array}{l}\text { tube } \\
\text { rcle } \\
\text { s }\end{array}$ & - & - & - & - & - & - & $\begin{array}{c}\text { Kne } \\
\text { r, } \\
186 \\
6\end{array}$ \\
\hline $\begin{array}{l}\text { Guizou } \\
\text { coelac } \\
\text { anthus }\end{array}$ & $\begin{array}{c}G . \\
\text { guanl }\end{array}$ & $\begin{array}{c}\text { oval } \\
- \\
\text { quad }\end{array}$ & $\begin{array}{l}\text { stou } \\
t \\
\text { ridg }\end{array}$ & $\begin{array}{l}\text { con } \\
\text { cen } \\
\text { tri }\end{array}$ & - & - & - & - & - & $\begin{array}{l}\text { Liu } \\
\text { et } \\
\text { al. }\end{array}$ \\
\hline
\end{tabular}




\begin{tabular}{|c|c|c|c|c|c|c|c|c|c|c|}
\hline & $\begin{array}{c}\text { ingen } \\
\text { sis }\end{array}$ & $\begin{array}{l}\text { rang } \\
\text { ular }\end{array}$ & $\begin{array}{c}\text { es } \\
\text { and } \\
\text { elon } \\
\text { gate } \\
\text { tube } \\
\text { rcle } \\
\text { s }\end{array}$ & $\begin{array}{c}\text { c } \\
\text { gro } \\
\text { wth } \\
\text { rin } \\
\text { gs }\end{array}$ & & & & & & $\begin{array}{c}2^{\prime} 00 \\
6 ; \\
\text { Gen } \\
9 \\
\text { et } \\
\text { al. } \\
2^{\prime} 00 \\
9\end{array}$ \\
\hline $\begin{array}{l}\text { Hadron } \\
\text { ector }\end{array}$ & $\begin{array}{c}H . \\
\text { donba } \\
\text { irdi }\end{array}$ & oval & $\begin{array}{l}\text { coar } \\
\text { se } \\
\text { ridg } \\
\text { es }\end{array}$ & - & - & - & - & - & - & $\begin{array}{c}\text { Lun } \\
d \& \& \\
\text { Lun } \\
\text { d, } \\
198 \\
4\end{array}$ \\
\hline $\begin{array}{c}\text { Hainbe } \\
\text { rgia }\end{array}$ & $\begin{array}{c}H . \\
\text { granu } \\
\text { lata }\end{array}$ & oval & $\begin{array}{c}\text { narr } \\
\text { ow } \\
\text { ridg } \\
\text { es }\end{array}$ & 8 & - & - & - & - & - & $\begin{array}{c}\text { Sch } \\
\text { wei } \\
\text { zer } \\
\prime \\
196 \\
6\end{array}$ \\
\hline \multirow{2}{*}{$\begin{array}{c}\text { Heptan } \\
\text { ema }\end{array}$} & $\begin{array}{c}H . \\
\text { parad } \\
\text { oxum }\end{array}$ & \multirow[t]{2}{*}{ oval } & \multirow{2}{*}{$\begin{array}{c}\text { prom } \\
\text { inen } \\
t \\
\text { medi } \\
\text { an } \\
\text { ridg } \\
\text { e } \\
\text { and } \\
\text { smal } \\
\text { ler } \\
\text { late } \\
\text { ral } \\
\text { ridg } \\
\text { es }\end{array}$} & - & - & - & - & - & - & $\begin{array}{c}\text { Bel } \\
\text { lot } \\
\text { i, } \\
185 \\
7 \text {; } \\
\text { For } \\
\text { ey, } \\
199 \\
8\end{array}$ \\
\hline & H. sp & & & - & - & - & & - & - & $\begin{array}{c}\text { Ren } \\
\text { est } \\
0 \& \\
\text { Sto } \\
\text { cka } \\
r, \\
201 \\
8\end{array}$ \\
\hline $\begin{array}{l}\text { Holoph } \\
\text { agus }\end{array}$ & $\begin{array}{l}\text { H. } \\
\text { gulo }\end{array}$ & oval & $\begin{array}{c}\text { elon } \\
\text { gate } \\
\text { ridg } \\
\text { es } \\
\text { and } \\
\text { tube } \\
\text { rcle } \\
\text { s }\end{array}$ & - & - & - & - & - & - & $\begin{array}{l}\text { For } \\
\text { ey, } \\
199 \\
8\end{array}$ \\
\hline $\begin{array}{c}\text { Holopt } \\
\text { erygiu } \\
\text { s }\end{array}$ & $\begin{array}{c}\text { H. } \\
\text { nudus }\end{array}$ & $\begin{array}{l}\text { spin } \\
\text { dle- } \\
\text { shap } \\
\text { ed }\end{array}$ & $\begin{array}{c}\text { unor } \\
\text { name } \\
\text { nted } \\
\text { ? }\end{array}$ & - & - & - & - & - & - & $\begin{array}{c}\text { Jes } \\
\text { sen } \\
\boldsymbol{\prime}\end{array}$ \\
\hline
\end{tabular}




\begin{tabular}{|c|c|c|c|c|c|c|c|c|c|c|}
\hline & & $\begin{array}{c}\text { (ven } \\
\text { trom } \\
\text { edia } \\
\text { n } \\
\text { scal } \\
\text { es) }\end{array}$ & & & & & & & & $\begin{array}{c}197 \\
3 ; \\
\text { Fri } \\
\text { edm } \\
\text { an } \\
\& \\
\text { Coa } \\
\text { tes } \\
200 \\
6\end{array}$ \\
\hline $\begin{array}{l}\text { Indoco } \\
\text { elacan } \\
\text { thus }\end{array}$ & $\begin{array}{c}\text { I. } \\
\text { robus } \\
\text { tus }\end{array}$ & oval & $\begin{array}{c}\text { smal } \\
1 \\
\text { ridg } \\
\text { es } \\
\text { and } \\
\text { stri } \\
\text { atio } \\
\text { ns }\end{array}$ & $\begin{array}{c}\text { con } \\
\text { cen } \\
\text { tri } \\
\text { c } \\
\text { gro } \\
\text { wth } \\
\text { rin } \\
\text { gs }\end{array}$ & $\begin{array}{c}\text { con } \\
\text { cen } \\
\text { tri } \\
\text { c } \\
\text { gro } \\
\text { wth } \\
\text { rin } \\
\text { gs }\end{array}$ & - & - & - & - & $\begin{array}{c}\mathrm{Jai} \\
\mathrm{n}, \\
197 \\
4\end{array}$ \\
\hline Laugia & $\begin{array}{c}\text { L. } \\
\text { groen } \\
\text { landi } \\
\text { ca }\end{array}$ & $\begin{array}{c}\text { ovat } \\
e\end{array}$ & $\begin{array}{c}\text { flat } \\
\text { tene } \\
\text { d } \\
\text { ridg } \\
\text { es }\end{array}$ & - & - & - & - & - & - & $\begin{array}{c}\text { Ste } \\
\text { nsi } \\
\text { ö, } \\
193 \\
2\end{array}$ \\
\hline Libys & $\begin{array}{c}\text { I. } \\
\text { polyp } \\
\text { terus }\end{array}$ & oval & $\begin{array}{l}\text { shor } \\
t \\
\text { ridg } \\
\text { es }\end{array}$ & 8 & & - & - & - & - & $\begin{array}{c}\text { Mün } \\
\text { ste } \\
r, \\
184 \\
2\end{array}$ \\
\hline $\begin{array}{c}\text { Lualab } \\
\text { aea }\end{array}$ & $\begin{array}{c}L \\
\text { henry } \\
i\end{array}$ & $\begin{array}{c}\text { ovat } \\
e\end{array}$ & $\begin{array}{l}\text { coar } \\
\text { se } \\
\text { ridg } \\
\text { es }\end{array}$ & - & - & - & & - & - & $\begin{array}{c}\text { Sai } \\
\text { nt- } \\
\text { Sei } \\
\text { ne, } \\
195 \\
5 ; \\
\text { For } \\
\text { ey, } \\
199 \\
8\end{array}$ \\
\hline $\begin{array}{c}\text { Luopin } \\
\text { gcoela } \\
\text { canthu } \\
\text { s }\end{array}$ & $\begin{array}{c}\text { L. } \\
\text { euryl } \\
\text { acrim } \\
\text { alis }\end{array}$ & $\begin{array}{c}\text { ovat } \\
e\end{array}$ & $\begin{array}{l}\text { stou } \\
\text { t } \\
\text { ridg } \\
\text { es } \\
\text { and } \\
\text { elon } \\
\text { gate } \\
\text { tube } \\
\text { rcle } \\
\text { s }\end{array}$ & $\begin{array}{l}\text { thi } \\
\text { n } \\
\text { rad } \\
\text { ial } \\
\text { rid } \\
\text { ges } \\
?\end{array}$ & $\begin{array}{l}\text { smo } \\
\text { oth }\end{array}$ & - & - & - & - & $\begin{array}{c}\text { Wen } \\
\text { et } \\
\text { al. } \\
{ }^{\prime} \\
201 \\
3\end{array}$ \\
\hline $\begin{array}{c}\text { Macrop } \\
\text { oma }\end{array}$ & $\begin{array}{c}M . \\
\text { lewes }\end{array}$ & oval & $\begin{array}{c}\operatorname{larg} \\
e\end{array}$ & $\begin{array}{l}\text { con } \\
\text { cen }\end{array}$ & - & $\begin{array}{c}\text { ename } \\
1\end{array}$ & $\begin{array}{l}\text { ort } \\
\text { hod }\end{array}$ & $\begin{array}{l}\text { ost } \\
\text { eon }\end{array}$ & $\begin{array}{c}\text { ful } \\
l_{y}\end{array}$ & $\begin{array}{l}\text { Wil } \\
\text { lia }\end{array}$ \\
\hline
\end{tabular}




\begin{tabular}{|c|c|c|c|c|c|c|c|c|c|c|}
\hline & $\begin{array}{c}\text { iensi } \\
S\end{array}$ & & $\begin{array}{c}\text { tube } \\
\text { rcle } \\
\text { s }\end{array}$ & $\begin{array}{c}\text { tri } \\
\text { c } \\
\text { gro } \\
\text { wth } \\
\text { rin } \\
\text { gs }\end{array}$ & & & $\begin{array}{c}\text { ent } \\
\text { ine } \\
\text { ' } \\
\text { lar } \\
\text { ge } \\
\text { pul } \\
\text { p } \\
\text { cav } \\
\text { iti } \\
\text { es }\end{array}$ & $\begin{array}{l}\text { al } \\
\text { rem } \\
\text { ode } \\
\text { lin } \\
\mathrm{g}\end{array}$ & $\begin{array}{l}\text { min } \\
\text { era } \\
\text { liz } \\
\text { ed }\end{array}$ & $\begin{array}{c}\text { mso } \\
\text { n, } \\
184 \\
9 ; \\
\text { For } \\
\text { ey, } \\
199 \\
8\end{array}$ \\
\hline & $\begin{array}{c}M . \\
\text { precu } \\
\text { rsor }\end{array}$ & & & - & - & - & - & - & - & $\begin{array}{l}\text { For } \\
\text { ey, } \\
199 \\
8\end{array}$ \\
\hline & $\begin{array}{c}M . \\
\text { speci } \\
\text { osum }\end{array}$ & & & - & - & - & - & - & - & $\begin{array}{l}\text { For } \\
\text { ey, } \\
199 \\
8\end{array}$ \\
\hline $\begin{array}{c}\text { Macrop } \\
\text { omoide } \\
\text { s }\end{array}$ & $\begin{array}{c}M . \\
\text { orien } \\
\text { talis }\end{array}$ & oval & $\begin{array}{c}\text { larg } \\
\text { e } \\
\text { tube } \\
\text { rcle } \\
\text { s }\end{array}$ & - & - & - & - & - & - & $\begin{array}{l}\text { For } \\
\text { ey, } \\
199 \\
8\end{array}$ \\
\hline $\begin{array}{c}\text { Mawson } \\
\text { ia }\end{array}$ & $\begin{array}{c}M . \\
\text { brasi } \\
\text { liens } \\
\text { is }\end{array}$ & oval & $\begin{array}{l}\text { unor } \\
\text { name } \\
\text { nted }\end{array}$ & $\begin{array}{c}\text { con } \\
\text { cen } \\
\text { tri } \\
\text { c } \\
\text { gro } \\
\text { wth } \\
\text { rin } \\
\text { gs }\end{array}$ & & $\begin{array}{c}\text { absen } \\
t ?\end{array}$ & $\begin{array}{c}\text { abs } \\
\text { ent } \\
?\end{array}$ & $\begin{array}{l}\text { pre } \\
\text { sen } \\
t\end{array}$ & - & $\begin{array}{l}\text { Yab } \\
\text { umo } \\
\text { to, } \\
200 \\
2\end{array}$ \\
\hline $\begin{array}{l}\text { Megalo } \\
\text { coelac } \\
\text { anthus }\end{array}$ & $\begin{array}{c}M . \\
\text { dobie } \\
i\end{array}$ & oval & - & $\begin{array}{c}\text { con } \\
\text { cen } \\
\text { tri } \\
\text { c } \\
\text { gro } \\
\text { wth } \\
\text { rin } \\
\text { gs }\end{array}$ & - & - & & - & - & $\begin{array}{c}\text { Dut } \\
\text { el } \\
\text { et } \\
\text { al. } \\
2^{\prime} 01 \\
2\end{array}$ \\
\hline $\begin{array}{c}\text { Miguas } \\
\text { haia }\end{array}$ & $\begin{array}{c}M . \\
\text { burea } \\
\text { ui }\end{array}$ & $\begin{array}{l}\text { subc } \\
\text { ircu } \\
\text { lar }\end{array}$ & $\begin{array}{c}\text { nume } \\
\text { rous } \\
\text { tube } \\
\text { rcle } \\
\text { s, } \\
\text { smal } \\
1 \\
\text { ridg } \\
\text { es } \\
\text { and } \\
\text { fine } \\
\text { stri }\end{array}$ & $\begin{array}{l}\text { thi } \\
\text { n } \\
\text { rad } \\
\text { ial } \\
\text { rid } \\
\text { ges } \\
\text { ' } \\
\text { con } \\
\text { cen } \\
\text { tri } \\
\text { c } \\
\text { gro }\end{array}$ & $\begin{array}{c}\text { con } \\
\text { cen } \\
\text { tri } \\
\text { c } \\
\text { gro } \\
\text { wth } \\
\text { rin } \\
\text { gs } \\
\text { and } \\
\text { bum } \\
\text { ps } \\
\text { pos }\end{array}$ & $\begin{array}{c}\text { ename } \\
1\end{array}$ & $\begin{array}{c}\text { ort } \\
\text { hod } \\
\text { ent } \\
\text { ine } \\
\text { ' } \\
\text { sma } \\
\text { ll } \\
\text { pul } \\
\text { p } \\
\text { cav } \\
\text { iti } \\
\text { es, }\end{array}$ & $\begin{array}{l}\text { ost } \\
\text { eon } \\
\text { al } \\
\text { rem } \\
\text { ode } \\
\text { lin } \\
\text { g, } \\
\text { emb } \\
\text { edd } \\
\text { ed } \\
\text { odo }\end{array}$ & $\begin{array}{c}\text { ful } \\
\text { ly } \\
\text { min } \\
\text { era } \\
\text { liz } \\
\text { ed }\end{array}$ & $\begin{array}{l}\text { thi } \\
\text { s } \\
\text { stu } \\
d y\end{array}$ \\
\hline
\end{tabular}




\begin{tabular}{|c|c|c|c|c|c|c|c|c|c|c|}
\hline & & & $\begin{array}{l}\text { atio } \\
\text { ns } \\
\text { post } \\
\text { erio } \\
\text { rly }\end{array}$ & $\begin{array}{l}\text { wth } \\
\text { rin } \\
\text { gs, } \\
\text { and } \\
\text { spo } \\
\text { on- } \\
\text { sha } \\
\text { ped } \\
\text { tub } \\
\text { erc } \\
\text { les }\end{array}$ & $\begin{array}{l}\text { ter } \\
\text { ior } \\
\text { ly }\end{array}$ & & $\begin{array}{l}\text { sup } \\
\text { eri } \\
\text { mpo } \\
\text { sed } \\
\text { odo } \\
\text { nto } \\
\text { des }\end{array}$ & $\begin{array}{l}\text { nto } \\
\text { des }\end{array}$ & & \\
\hline $\begin{array}{c}\text { Mylaca } \\
\text { nthus }\end{array}$ & $\begin{array}{c}\text { M. } \\
\text { lobat } \\
\text { us }\end{array}$ & oval & $\begin{array}{c}\text { smal } \\
1 \\
\text { coar } \\
\text { se } \\
\text { ridg } \\
\text { es }\end{array}$ & - & - & - & - & - & - & $\begin{array}{l}\text { Ste } \\
\text { nsi } \\
\ddot{0}, \\
192 \\
1\end{array}$ \\
\hline $\begin{array}{c}\text { Parnai } \\
\text { baia }\end{array}$ & $\begin{array}{c}P . \\
\text { maran } \\
\text { haoen } \\
\text { sis }\end{array}$ & $\begin{array}{c}\text { ovat } \\
e\end{array}$ & $\begin{array}{c}\text { prom } \\
\text { inen } \\
t \\
\text { medi } \\
\text { an } \\
\text { ridg } \\
\text { es } \\
\text { and } \\
\text { smal } \\
\text { ler } \\
\text { late } \\
\text { ral } \\
\text { ridg } \\
\text { es }\end{array}$ & 8 & - & - & - & - & - & $\begin{array}{c}\text { Yab } \\
\text { umo } \\
\text { to, } \\
200 \\
8\end{array}$ \\
\hline $\begin{array}{c}\text { Pivete } \\
\text { auia }\end{array}$ & $\begin{array}{c}P . \\
\text { madag } \\
\text { ascar } \\
\text { ensis }\end{array}$ & oval & $\begin{array}{l}\text { elon } \\
\text { gate } \\
\text { ridg } \\
\text { es }\end{array}$ & - & - & - & - & - & - & $\begin{array}{c}\text { Clé } \\
\text { men } \\
t, \\
199 \\
9\end{array}$ \\
\hline $\begin{array}{l}\text { Rebell } \\
\text { atrix }\end{array}$ & $\begin{array}{c}R . \\
\text { divar } \\
\text { icerc } \\
a\end{array}$ & oval & $\begin{array}{l}\text { narr } \\
\text { ow } \\
\text { ridg } \\
\text { es }\end{array}$ & - & - & - & - & - & - & $\begin{array}{c}\text { Wen } \\
\text { dru } \\
f \& \\
\text { Wil } \\
\text { son } \\
2^{\prime} 01 \\
2\end{array}$ \\
\hline \multirow{2}{*}{$\begin{array}{c}\text { Rhabdo } \\
\text { derma }\end{array}$} & $\begin{array}{c}R . \\
\text { ardro } \\
\text { ssens } \\
e\end{array}$ & \multirow[t]{2}{*}{ oval } & \multirow{2}{*}{$\begin{array}{c}\text { post } \\
\text { erio } \\
\text { rly } \\
\text { conv } \\
\text { erge } \\
\text { nt } \\
\text { ridg }\end{array}$} & - & - & - & - & - & - & $\begin{array}{l}\text { For } \\
\text { ey, } \\
199 \\
8\end{array}$ \\
\hline & $\begin{array}{c}R . \\
\text { elega } \\
n S\end{array}$ & & & - & - & - & - & - & - & $\begin{array}{l}\text { For } \\
\text { ey, }\end{array}$ \\
\hline
\end{tabular}




\begin{tabular}{|c|c|c|c|c|c|c|c|c|c|c|}
\hline & & & \multirow[t]{5}{*}{ es } & & & & & & & $\begin{array}{c}199 \\
8\end{array}$ \\
\hline & $\begin{array}{c}R . \\
\text { exigu } \\
\text { um }\end{array}$ & & & - & - & - & - & - & - & $\begin{array}{c}\text { For } \\
\text { ey, } \\
199 \\
8\end{array}$ \\
\hline & $\begin{array}{c}R . \\
\text { huxle } \\
y i\end{array}$ & & & - & - & - & - & - & - & $\begin{array}{l}\text { For } \\
\text { ey, } \\
199 \\
8\end{array}$ \\
\hline & $\begin{array}{c}R . \\
\text { madag } \\
\text { ascar } \\
\text { ensis }\end{array}$ & & & - & - & - & - & - & - & $\begin{array}{c}\text { For } \\
\text { ey, } \\
199 \\
8\end{array}$ \\
\hline & $\begin{array}{c}R . \\
\text { tingl } \\
y e n s i \\
s \\
\end{array}$ & & & - & - & - & - & - & - & $\begin{array}{c}\text { For } \\
\text { ey, } \\
199 \\
8 \\
\end{array}$ \\
\hline $\begin{array}{c}\text { Sassen } \\
\text { ia }\end{array}$ & $\begin{array}{c}S . \\
\text { groen } \\
\text { landi } \\
\text { ca }\end{array}$ & \multirow[b]{2}{*}{ oval } & \multirow{2}{*}{$\begin{array}{c}\text { tube } \\
\text { rcle } \\
\text { s } \\
\text { and } \\
\text { smal } \\
1 \\
\text { ridg } \\
\text { es }\end{array}$} & - & - & - & - & - & - & $\begin{array}{c}\text { For } \\
\text { ey, } \\
199 \\
8\end{array}$ \\
\hline $\begin{array}{c}\text { Sassen } \\
\text { ia }\end{array}$ & $\begin{array}{c}S . \\
\text { tuber } \\
\text { culat } \\
\text { a }\end{array}$ & & & - & & - & - & - & - & $\begin{array}{c}\text { Ste } \\
\text { nsi } \\
\text { Ö, } \\
193 \\
2\end{array}$ \\
\hline $\begin{array}{c}\text { Sclera } \\
\text { canthu } \\
s\end{array}$ & $\begin{array}{c}S . \\
\text { asper }\end{array}$ & $\begin{array}{c}\text { ovat } \\
e\end{array}$ & $\begin{array}{c}\text { coar } \\
\text { se, } \\
\text { shar } \\
\text { p } \\
\text { ridg } \\
\text { es }\end{array}$ & - & - & & - & - & - & $\begin{array}{c}\text { Ste } \\
\text { nsi } \\
\text { Ö, } \\
192 \\
1\end{array}$ \\
\hline $\begin{array}{l}\text { Sereni } \\
\text { chthys }\end{array}$ & $\begin{array}{c}\text { S. } \\
\text { kowie } \\
\text { nsis }\end{array}$ & oval & $\begin{array}{l}\text { elon } \\
\text { gate } \\
\text { ridg } \\
\text { es }\end{array}$ & - & - & - & & - & - & $\begin{array}{c}\text { Ges } \\
\text { s \& } \\
\text { Coa } \\
\text { tes } \\
2^{\prime} 01 \\
5\end{array}$ \\
\hline $\begin{array}{l}\text { Sinoco } \\
\text { elacan } \\
\text { thus }\end{array}$ & $\begin{array}{c}\text { S. } \\
\text { fengs } \\
\text { hanen } \\
\text { sis }\end{array}$ & oval & - & $\begin{array}{c}\text { con } \\
\text { cen } \\
\text { tri } \\
\text { c } \\
\text { gro } \\
\text { wth } \\
\text { rin } \\
\text { gs }\end{array}$ & - & - & - & - & - & $\begin{array}{l}\text { Liu } \\
\text { ' } \\
196 \\
4\end{array}$ \\
\hline $\begin{array}{c}\text { Sperma } \\
\text { todus }\end{array}$ & $\begin{array}{c}\text { S. } \\
\text { pustu } \\
\text { losus }\end{array}$ & oval & $\begin{array}{c}\text { tube } \\
\text { rcle } \\
\mathrm{s}\end{array}$ & - & - & $\begin{array}{c}\text { prese } \\
\text { nt }\end{array}$ & $\begin{array}{c}\text { pre } \\
\text { sen } \\
t\end{array}$ & $\begin{array}{c}\text { pre } \\
\text { sen } \\
t\end{array}$ & - & $\begin{array}{l}\text { Wes } \\
\text { tol } \\
1,\end{array}$ \\
\hline
\end{tabular}




\begin{tabular}{|c|c|c|c|c|c|c|c|c|c|c|}
\hline & & & & & & $\begin{array}{c}\text { (derm } \\
\text { al } \\
\text { bones } \\
\text { ) }\end{array}$ & $\begin{array}{c}\text { (de } \\
\text { rma } \\
1 \\
\text { bon } \\
\text { es ) }\end{array}$ & $\begin{array}{c}\text { (de } \\
\text { rma } \\
1 \\
\text { bon } \\
\text { es) } \\
\end{array}$ & & $\begin{array}{c}193 \\
9: \\
\text { Mei } \\
\text { nke } \\
{ }^{\prime} \\
198 \\
2\end{array}$ \\
\hline $\begin{array}{c}\text { Swenzi } \\
a\end{array}$ & $\begin{array}{c}S . \\
\text { latim } \\
\text { erae }\end{array}$ & oval & $\begin{array}{l}\text { elon } \\
\text { gate } \\
\text { tube } \\
\text { rcle } \\
\text { s } \\
\end{array}$ & - & - & - & - & - & - & $\begin{array}{c}\text { Clé } \\
\text { men } \\
t, \\
200 \\
5\end{array}$ \\
\hline $\begin{array}{c}\text { Ticine } \\
\text { pomis }\end{array}$ & $\begin{array}{c}\text { T. } \\
\text { cf. } \\
\text { T. } \\
\text { peyer } \\
i\end{array}$ & oval & $\begin{array}{l}\text { elon } \\
\text { gate } \\
\text { ridg } \\
\text { es }\end{array}$ & - & - & - & - & - & - & $\begin{array}{c}\mathrm{Cav} \\
\text { in } \\
\text { et } \\
\text { al. } \\
2^{\prime} 01 \\
3\end{array}$ \\
\hline $\begin{array}{c}\text { Trachy } \\
\text { metopo } \\
n\end{array}$ & $\begin{array}{c}\text { T. } \\
\text { Iiass } \\
\text { icum, }\end{array}$ & oval & $\begin{array}{l}\text { elon } \\
\text { gate } \\
\text { ridg } \\
\text { es }\end{array}$ & & - & - & - & - & - & $\begin{array}{c}\text { Dut } \\
\text { el } \\
\text { et } \\
\text { al. } \\
2^{\prime} 01 \\
5\end{array}$ \\
\hline \multirow{3}{*}{ Undina } & $\begin{array}{c}\text { U. } \\
\text { cirin } \\
\text { ensis }\end{array}$ & \multirow{3}{*}{ oval } & \multirow{3}{*}{$\begin{array}{c}\text { elon } \\
\text { gate } \\
\text { tube } \\
\text { rcle } \\
\text { s } \\
\text { and } \\
\text { ridg } \\
\text { es }\end{array}$} & - & - & & - & - & - & $\begin{array}{l}\text { Sai } \\
\text { nt- } \\
\text { Sei } \\
\text { ne, } \\
194 \\
9\end{array}$ \\
\hline & $\begin{array}{c}U . \\
\text { penic } \\
\text { illat } \\
\text { a }\end{array}$ & & & - & - & $\begin{array}{c}\text { absen } \\
t\end{array}$ & $\begin{array}{c}\text { ort } \\
\text { hod } \\
\text { ent } \\
\text { ine } \\
, \\
\text { lar } \\
\text { ge } \\
\text { pul } \\
\text { p } \\
\text { cav } \\
\text { iti } \\
\text { es }\end{array}$ & $\begin{array}{c}\text { ost } \\
\text { eon } \\
\text { al } \\
\text { rem } \\
\text { ode } \\
\text { lin } \\
\text { g? } \\
\text { emb } \\
\text { edd } \\
\text { ed } \\
\text { odo } \\
\text { nto } \\
\text { des }\end{array}$ & - & $\begin{array}{c}\text { Mün } \\
\text { ste } \\
\text { r, } \\
183 \\
4 ; \\
\text { Gro } \\
\text { ss, } \\
193 \\
5, \\
196 \\
6\end{array}$ \\
\hline & $\begin{array}{c}\text { U. } \\
\text { purbe } \\
\text { ckens } \\
\text { is }\end{array}$ & & & - & - & - & - & - & - & $\begin{array}{l}\text { Woo } \\
\text { dwa } \\
\text { rd, } \\
191 \\
6\end{array}$ \\
\hline
\end{tabular}




\begin{tabular}{|c|c|c|c|c|c|c|c|c|c|c|}
\hline \multirow{5}{*}{$\begin{array}{c}\text { Whitei } \\
a\end{array}$} & $\begin{array}{c}\text { W. } \\
\text { niels } \\
\text { eni }\end{array}$ & \multirow{5}{*}{ oval } & $\begin{array}{l}\text { shor } \\
t \\
\text { ridg } \\
\text { es }\end{array}$ & - & - & - & - & - & - & $\begin{array}{l}\text { For } \\
\text { ey, } \\
199 \\
8\end{array}$ \\
\hline & $\begin{array}{c}W \\
\text { oishi } \\
i\end{array}$ & & $\begin{array}{l}\text { elon } \\
\text { gate } \\
\text { ridg } \\
\text { es }\end{array}$ & - & - & - & - & - & - & $\begin{array}{c}\text { Yab } \\
\text { umo } \\
\text { to } \\
\& \\
\text { Bri } \\
\text { to, } \\
201 \\
6\end{array}$ \\
\hline & $\begin{array}{c}W \cdot \\
\text { tuber } \\
\text { culat } \\
\text { a }\end{array}$ & & $\begin{array}{c}\text { tube } \\
\text { rcle } \\
\text { s }\end{array}$ & - & - & - & - & - & - & $\begin{array}{l}\text { For } \\
\text { ey, } \\
199 \\
8\end{array}$ \\
\hline & $\begin{array}{c}W . \\
\text { uyeno } \\
\text { teruy } \\
\text { ai }\end{array}$ & & $\begin{array}{l}\text { elon } \\
\text { gate } \\
\text { ridg } \\
\text { es }\end{array}$ & 8 & - & - & - & - & - & $\begin{array}{c}\text { Yab } \\
\text { umo } \\
\text { to } \\
\text { et } \\
\text { al. } \\
\text { '́ } \\
201 \\
9\end{array}$ \\
\hline & $\begin{array}{c}W . \\
\text { woodw } \\
\text { ardi }\end{array}$ & & $\begin{array}{l}\text { elon } \\
\text { gate } \\
\text { tube } \\
\text { rcle } \\
\text { s }\end{array}$ & 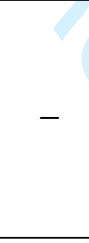 & - & - & - & - & - & $\begin{array}{l}\text { For } \\
\text { ey, } \\
199 \\
8\end{array}$ \\
\hline $\begin{array}{c}\text { Wimani } \\
a\end{array}$ & $\begin{array}{c}\text { W. } \\
\text { sinuo } \\
\text { sa }\end{array}$ & $\begin{array}{c}\text { ovat } \\
e\end{array}$ & $\begin{array}{l}\text { shor } \\
t \\
\text { ridg } \\
\text { es }\end{array}$ & $\begin{array}{c}\text { con } \\
\text { cen } \\
\text { tri } \\
\text { c } \\
\text { gro } \\
\text { wth } \\
\text { rin } \\
\text { gs }\end{array}$ & - & - & - & - & - & $\begin{array}{l}\text { Ste } \\
\text { nsi } \\
\ddot{0}, \\
192 \\
1\end{array}$ \\
\hline $\begin{array}{l}\text { Youngi } \\
\text { chthys }\end{array}$ & $\begin{array}{c}Y . \\
\text { xinhu } \\
\text { ainsi } \\
\text { s }\end{array}$ & oval & $\begin{array}{l}\text { narr } \\
\text { ow } \\
\text { ridg } \\
\text { es }\end{array}$ & - & - & - & - & - & - & $\begin{array}{c}\text { Wan } \\
9 \& \\
\text { Liu } \\
\text { ' } \\
198 \\
1\end{array}$ \\
\hline
\end{tabular}




\section{FIGURES}

FIGURE 1. Photographs of the fossil specimens of Miguashaia bureaui histologically surveyed. A. MHNM 06-1238. B. MHNM 061495. Abbreviations: cl, cleithrum; lp, lepidotrichia; n.ar, neural arches; op.s, opercular series; ra, radials, sc, scales. Scale bar equals $10 \mathrm{~mm}$.

FIGURE 2. Squamation of Miguashaia bureaui. A. Complete specimen (MHNM 06-494). B. Reconstruction and body outline of M. bureaui with the scales from three locations of the left flank highlighted. C-E. Reconstruction of different scales from the left flank: c. Scale from the anteroventral portion of the trunk, posterior to the pectoral fin, in external view, D. Scale from the posterior portion of the trunk, in external (1) and internal (2) view. E. Scale from the posterior-most region of the trunk, close to the caudal fin, in external view. Drawings based on MHNM 06-6, MHNM 06-641 (Cloutier, 1996; fig. 17), MHNM 06-1238, MHNM 06-1239, and MHNM 06-1495. Abbreviations: ci.b, circular bumps; co.tu, coarse tubercles; co.ri, coarse ridges; f.ri, fine ridges; pi.e, pitted enamel; sp.tu, spoon-shaped tubercles. Arrow points anteriorly. Scale bars equal $10 \mathrm{~cm}$ (A) and $10 \mathrm{~mm} \quad(\mathbf{C}-\mathbf{E})$.

FIGURE 3. General microstructural organization of the scales of Miguashaia bureaui (vertical cross sections of MHNM 06- 
1495). A. Superimposed odontodes from the superficial layer. B. Vascular bone (spongiosa) from the superficial layer. Arrow heads point to osteocytes embedded in the bone. C. Lamellar bone (isopedine) from the basal plate. Black arrows indicate the repetitive pattern of collagenous plies with the same orientation. Abbreviations: d1-2, dentine layer of two generations of odontodes; e1-2, enamel layer of two generations of odontodes; $\mathbf{1 b}$, lamellar bone; pc, pulp cavity; vb, vascular bone. Scale bar equals $50 \mu \mathrm{m}$.

FIGURE 4. Ornamentation and microstructural organization of the exposed area of the scales of Miguashaia bureaui (vertical cross sections of MHNM 06-1495). A. General view of a scale showing the distribution of the odontodes in the superficial layer. White arrow heads indicate the irregular front of mineralization of the ventral surface of the basal plate. B. Detail of an odontode composed of a thin layer of enamel and dentine with numerous odontoblastic canaliculi overlying the layer of vascular bone (spongiosa). C. Inset of two odontodes from $\mathbf{A}$. Note the opening of vascular canals from the spongiosa through pores in the surface, as in $\mathbf{B}$, and the large odontoblastic lacunae. Arrow heads indicate the occurrence of osteocyte lacunae in the lamellar bone (isopedine) of the basal plate. D-E. Different distributions and arrangements of two generations of superimposed odontodes. Note the reduced thickness of the spongiosa and the occurrence of vascular 
canals and vascular bone surrounding the older odontodes.

Abbreviations: bp, basal plate; d, dentine; d1-2, dentine layer of two generations of odontodes; e, enamel; e1-2, enamel layer of two generations of odontodes; 1b, lamellar bone; ml, middle layer; oc, odontoblastic canaliculi; od1-2, two generations of odontodes; vb, vascular bone; vc, vascular canal;. Scale bars equal $100 \mu \mathrm{m}$.

FIGURE 5. Ornamentation and microstructural organization of the overlapped area of the scales of Miguashaia bureaui (vertical and horizontal cross sections of MHNM 06-1238). A. Three scales vertically sectioned at different regions of the overlapped area (from anterior to posterior): 1) Anterior most margin; 2) Central region; 3) Posterior region, close to the contact with the exposed area. Note the increase in thickness of the vascular bone layer (spongiosa) and the lamellar bone layer (isopedine) from anterior to posterior and the changes in the bony ornamentation. Scale bar equals $500 \mu \mathrm{m}$. B. Bony ornamentations of the overlapped area from the anterior most margin (1) and the central region (2). Scale bar equals 100 um. C. Horizontal cross section through the small bony tubercles of the overlapped area from the anterior most margin of a scale (1). Note the concentric patterns of ossification, the radial arrangement of osteocyte lacunae, and the openings of vascular canals between the tubercles. Scale bar equals 50 um. Abbreviations: 1b, lamellar bone; vb, vascular bone. 
FIGURE 6. Microstructural and histological organization of the vascular bone of the scales of Miguashaia bureaui (horizontal cross sections of MHNM 06-1238). A. General view of the vascular bone layer (spongiosa) from the overlapped area of the scales. Note the uniform diameter and distribution of the vascular canals. Scale bar equals 500 um. B. Detailed inset from A. Note that each vascular canal is surrounded by a series of concentric layers of woven-fibered bone (light brown) while each row of vascular canals is separated from the other by a denser bone tissue (dark brown). Scale bar equals $100 \mu \mathrm{m}$. C. Detailed inset from B. Arrow heads indicate the occurrence of osteocyte lacunae surrounding the vascular canals. Scale bar equals $50 \mu \mathrm{m}$. D. General view of the vascular bone and vascular canals from another region of the overlapped area of a scale, probably from a more posterior region than in $\mathbf{A}$. Note the more irregular distribution of the vascular canals and the occurrence of ossification waves. Scale bar equals $100 \mu \mathrm{m}$. E. Detailed inset from D. Note the occurrence of large osteocyte lacunae in the woven-fibered bone around the vascular canals. Scale bar equals 50 um. F. Detailed inset from D. Arrow heads point to embedded osteocyte lacunae with large osteocytic prolongations. Scale bar equals $50 \mu \mathrm{m}$. 
FIGURE 7. Microstructural and histological organization of the basal plate of the scales of Miguashaia bureaui (vertical cross sections of MHNM 06-1238 and MHNM 06-1495). A. General view of the vascular bone layer (spongiosa) of the superficial layer and lamellar bone (isopedine) of the basal plate from the anterior portion of the overlapped area of the scales (MHNM 06-1238). The horizontal plane corresponds to the approximative cross section plane in Fig. 6D-F. Note the clear differences in bone structure between the spongiosa (made of woven-fibered bone) and the isopedine (made of lamellar bone). Scale bar equals $100 \mu \mathrm{m}$. B. Detailed view of the basal plate from the central portion of the exposed area of the scales (MHNM 06-1495). Black arrows indicate the repetitive pattern of collagenous plies with the same orientation. White arrow heads indicate the irregular front of mineralization of the visceral surface of the basal plate. The black arrow head points to a vertical vascular canal piercing the basal plate and opening through the ventral surface of the scale. Note that the thickness of the basal plate is more important around the vascular canal resulting in a bump of the internal surface of the scale at this point. Scale bar equals $100 \mu \mathrm{m}$.

Abbreviations: bp, basal plate; 1b, lamellar bone; sl, superficial layer; vb, vascular bone; vc, vascular canal.

FIGURE 8. Basal plate comparison of the scales of Miguashaia and Latimeria in horizontal cross section. A. Miguashaia 
bureaui (MHNM 06-1238). Note the occurrence of 5 directions of the collagen fibers. B. Latimeria chalumnae (MNHN-ZA-AC-201229). C. Latimeria menadoensis (MZB 10003). Note the arciform pattern of the collagen plies evidencing a twisted-plywood arrangement of the layers of the isopedine. Scale bars equal $100 \mu \mathrm{m}$

FIGURE 9. Odontodes from the exposed area of the scales of Latimeria (SEM). A. Latimeria menadoensis (MZB 10003). General view of the odontodes. The posterior margin of the scale is on the upper left of the image. The radial ridges of the superficial layer are clearly seen between the odontodes. Scale bar equals $500 \mathrm{\mu m}$. B-C. Latimeria menadoensis (MZB 10003). Detail of the odontodes and ridged surface of the superficial layer between the odontodes. Scale bar equals 100 um. D. Latimeria chalumnae (MNHN-ZA-AC-2012-26). Detail of the odontodes. The posterior margin of the scale is on the upper right of the image. Scale bar equals $100 \mu \mathrm{m}$.

FIGURE 10. Ornamentation and microstructural organization of the scales of Latimeria. A. Latimeria chalumnae (MNHN-ZA-AC2012-26). Transversal section of the exposed area of the scale in polarized light. The ornamented superficial layer displays eight odontodes (white arrow heads) with large pulp cavities and overlies the basal plate. Scale bar equals $1 \mathrm{~mm}$ (from Castanet et al., 1975). B. Latimeria menadoensis (MZB 10003). 
Longitudinal section of the exposed area in microradiography (anterior to the right). The ornamented superficial layer displays four odontodes (white arrowheads). Some vascular canals from the reduced spongiosa can be seen at the base of the odontodes. The whole basal plate is unmineralized and thus does not appear in the image, its approximative contour is represented with a white dashed line. Scale bar equals $1 \mathrm{~mm}$ (from Meunier et al., 2008). Abbreviations: bp, basal plate; pc, pulp cavity; vc, vascular canal.

FIGURE 11. Evolution of scale morphology and ornamentation in coelacanths. Phylogenetic hypothesis after Cavin et al. 2017. The date of the diverging nodes is hypothetical. Original artwork of Miguashaia and Latimeria and modified drawings of Wimania after Stensiö, 1921; Diplocercides after Stensiö, 1937; Diplurus after Schaeffer, 1952; Rhabdoderma, Sassenia, Whiteia, Lualabaea, Axelrodichthys, Holophagus, Macropoma after Forey, 1998; Guizhoucoelacanthus after Geng et al., 2009. Nodes: 1. Actinistia; 2. Coelacanthiformes; 3. Latimerioidei; 4. Mawsoniidae; 5. Latimeriidae. Anterior of the scales to the left.

FIGURE 12. Phylogenetic hypothesis on early actinistian coelacanth evolution with special emphasis on the squamation. A. Phylogenetic interrelationships of selected osteichthyans, highlighting the unresolved position of styloichthys and 
onychodonts (represented here by Selenodus) relative to coelacanths (including here Miguashaia and Latimeria) (consensus of phylogenetic hypotheses after Friedman, 2007; Lu et al., 2016a,b, 2017; Mondéjar-Fernández, 2020, among

others). Abbreviations: A: actinopterygians, C: coelacanths, D: dipnomorphs, $\mathbf{R}$ : rhipidistians, $\mathbf{s}$ : sarcopterygians, $\mathbf{T}$ : tetrapodomorphs. Original artwork of Miguashaia, Latimeria and Danio and modified drawings of Andreolepis after Gross, 1968; Neoceratodus after Brien, 1962; Porolepis, Osteolepis and Eusthenopteron after Jarvik, 1980; Cheirolepis after Pearson, 1982; Styloichthys after Lu \& Zhu, 2008; Psarolepis after Qu et al., 2013; Selenodus after Mondéjar-Fernández, 2020. Not to scale. B-E. Phylogenetic hypothesis of the possible interrelationships between Styloichthys, onychodonts (irrespective of their monophyly) and coelacanths. B. Onychodonts as stem coelacanths and Styloichthys as the sister group of coelacanths. C. Styloichthys as the sister group of the onychodont-coelacanth clade. D. Styloichthys as the sister group of the onychodont-coelacanth clade and rhipidistians. E. Onychodonts as the sister group of coelacanths (including Styloichthys) and rhipidistians. 

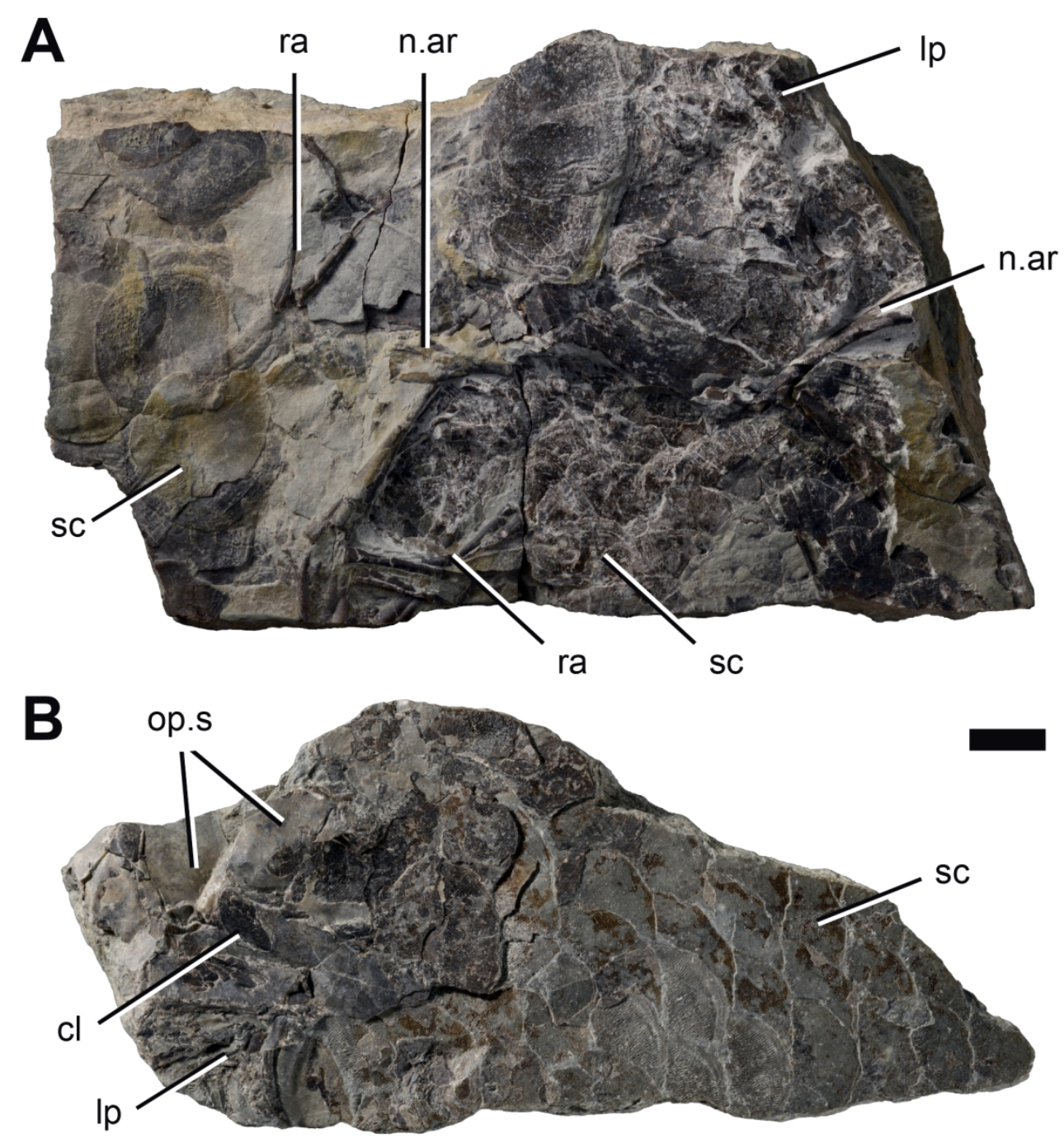

Photographs of the fossil specimens of Miguashaia bureaui histologically surveyed. A. MHNM 06-1238. B. MHNM 06-1495. Abbreviations: cl, cleithrum; Ip, lepidotrichia; n.ar, neural arches; op.s, opercular series; ra, radials, sc, scales. Scale bar equals $10 \mathrm{~mm}$. 
A

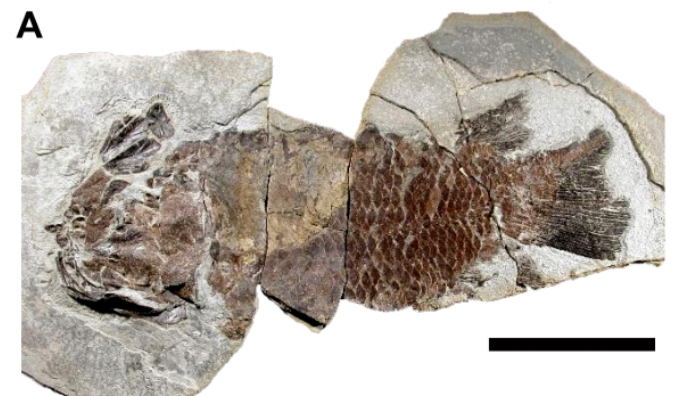

B

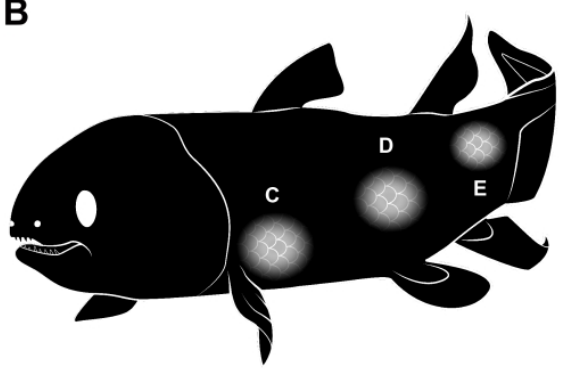

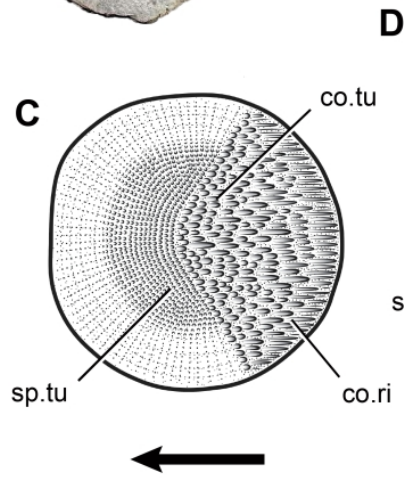
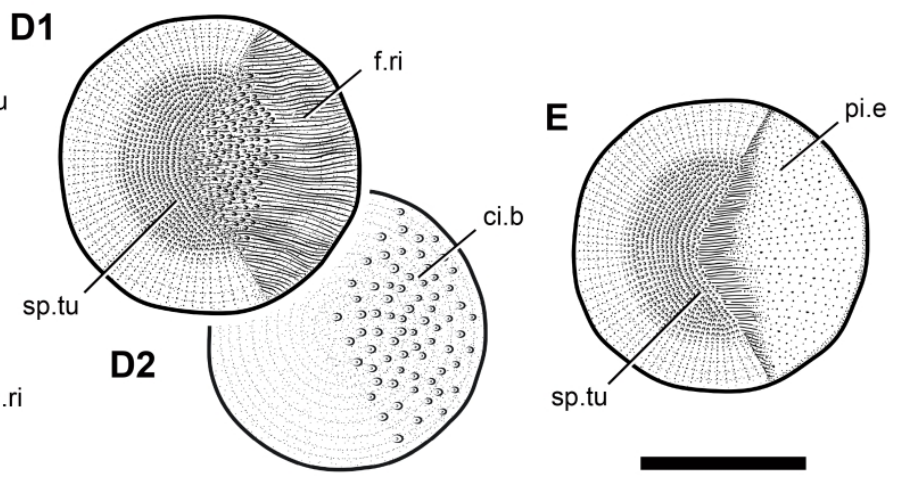

Squamation of Miguashaia bureaui. A. Complete specimen (MHNM 06-494). B. Reconstruction and body outline of M. bureaui with the scales from three locations of the left flank highlighted. C-E. Reconstruction of different scales from the left flank: C. Scale from the anteroventral portion of the trunk, posterior to the pectoral fin, in external view, D. Scale from the posterior portion of the trunk, in external (1) and internal

(2) view. E. Scale from the posterior-most region of the trunk, close to the caudal fin, in external view. Drawings based on MHNM 06-6, MHNM 06-641 (Cloutier 1996; fig. 17), MHNM 06-1238, MHNM 06-1239, and MHNM 06-1495. Abbreviations: ci.b, circular bumps; co.tu, coarse tubercles; co.ri, coarse ridges; f.ri, fine ridges; pi.e, pitted enamel; sp.tu, spoon-shaped tubercles. Arrow points anteriorly. Scale bars equal 10 $\mathrm{cm}(\mathrm{A})$ and $10 \mathrm{~mm}(\mathrm{C}-\mathrm{E})$. 

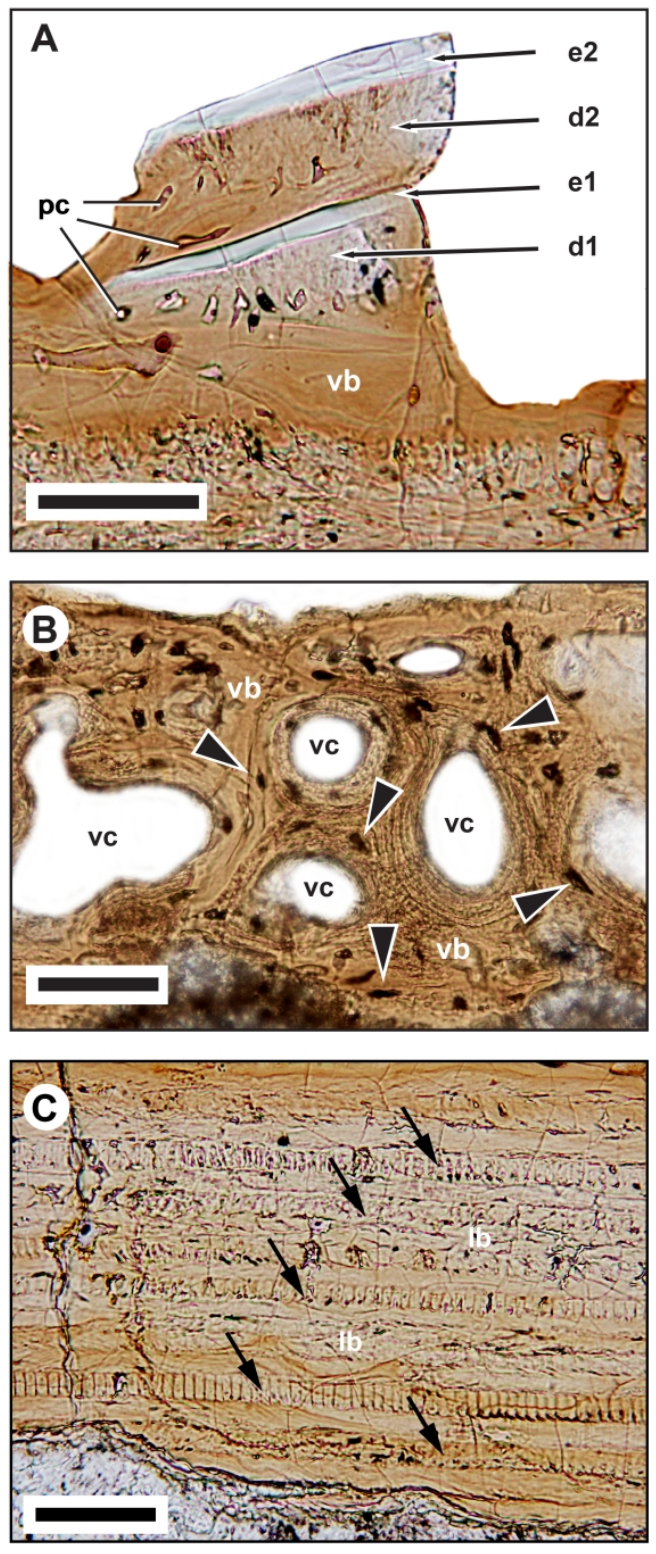

General microstructural organization of the scales of Miguashaia bureaui (vertical cross sections of MHNM 06-1495). A. Superimposed odontodes from the superficial layer. B. Vascular bone (spongiosa) from the superficial layer. Arrow heads point to osteocytes embedded in the bone. C. Lamellar bone (isopedine) from the basal plate. Black arrows indicate the repetitive pattern of collagenous plies with the same orientation. Abbreviations: d1-2, dentine layer of two generations of odontodes; e1-2, enamel layer of two generations of odontodes; Ib, lamellar bone; pc, pulp cavity; vb, vascular bone. Scale bar equals $50 \mu \mathrm{m}$. 

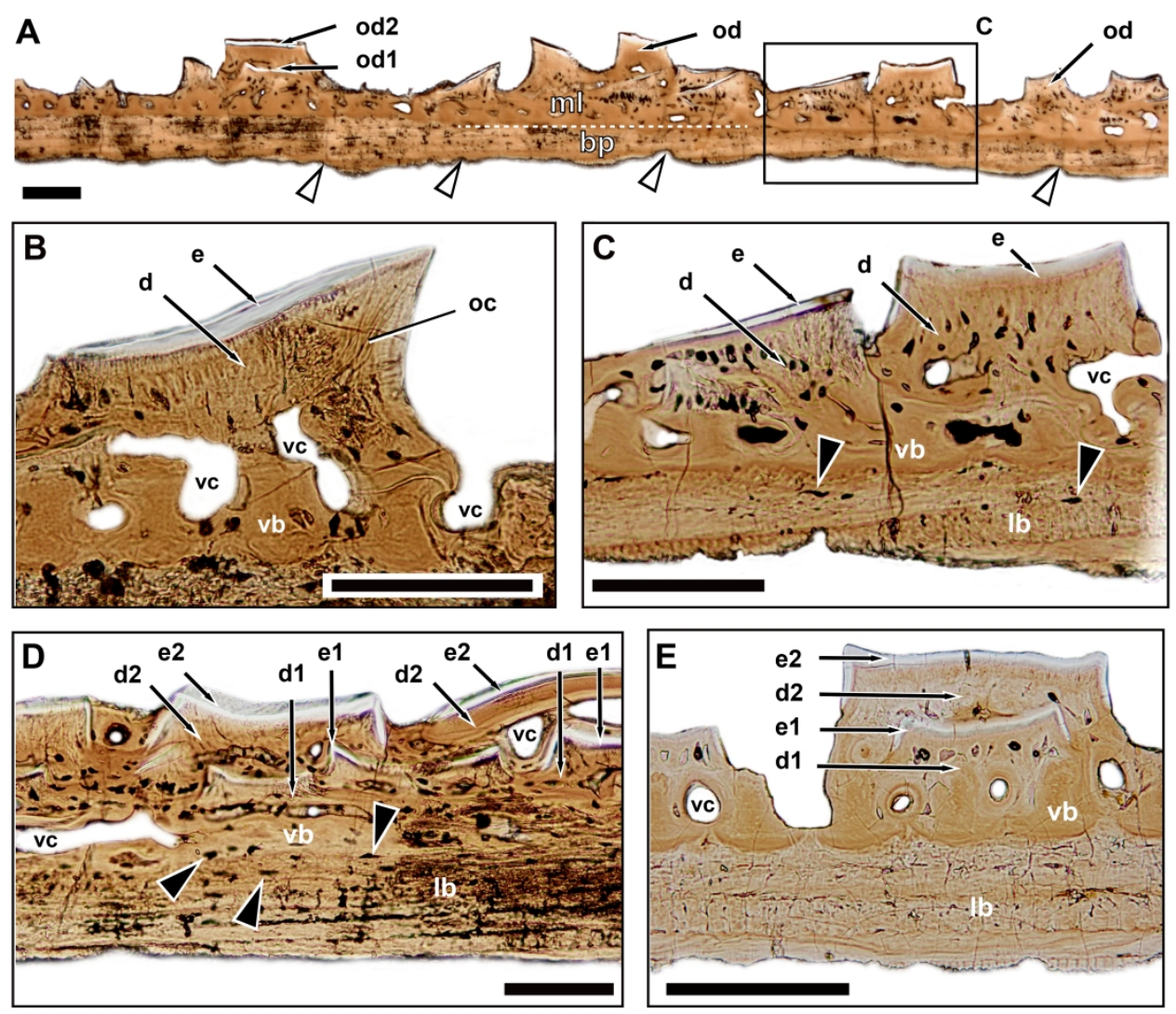

Ornamentation and microstructural organization of the exposed area of the scales of Miguashaia bureaui (vertical cross sections of MHNM 06-1495). A. General view of a scale showing the distribution of the odontodes in the superficial layer. White arrow heads indicate the irregular front of mineralization of the ventral surface of the basal plate. B. Detail of an odontode composed of a thin layer of enamel and dentine with numerous odontoblastic canaliculi overlying the layer of vascular bone (spongiosa). C. Inset of two odontodes from $A$. Note the opening of vascular canals from the spongiosa through pores in the surface, as in $B$, and the large odontoblastic lacunae. Arrow heads indicate the occurrence of osteocyte lacunae in the

lamellar bone (isopedine) of the basal plate. D-E. Different distributions and arrangements of two generations of superimposed odontodes. Note the reduced thickness of the spongiosa and the occurrence of vascular canals and vascular bone surrounding the older odontodes. Abbreviations: bp, basal plate; $d$, dentine; d1-2, dentine layer of two generations of odontodes; e, enamel; e1-2, enamel layer of two generations of odontodes; lb, lamellar bone; ml, middle layer; oc, odontoblastic canaliculi; od1-2, two generations of odontodes; vb, vascular bone; vc, vascular canal;. Scale bars equal $100 \mu \mathrm{m}$. 

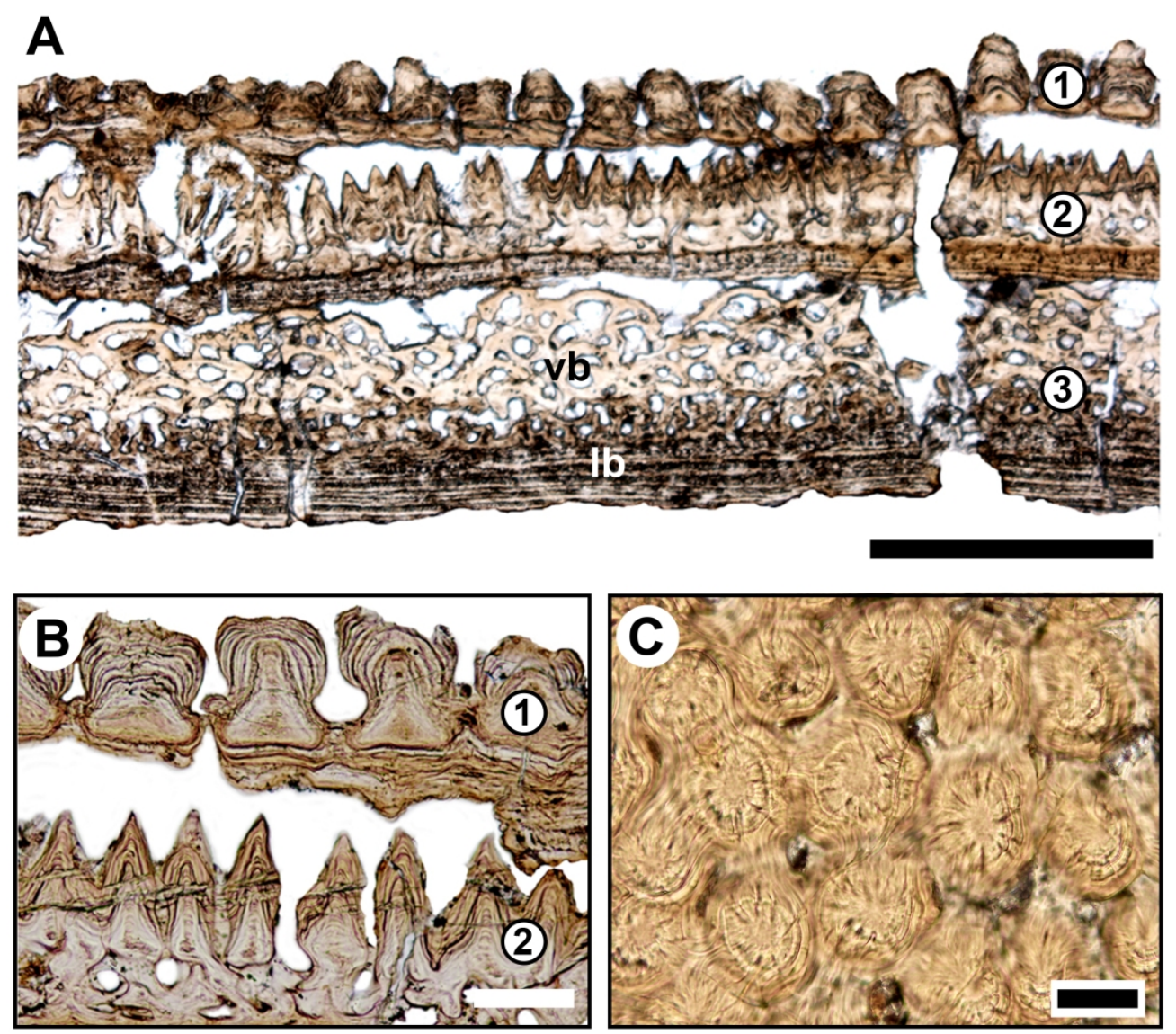

Ornamentation and microstructural organization of the overlapped area of the scales of Miguashaia bureaui (vertical and horizontal cross sections of MHNM 06-1238). A. Three scales vertically sectioned at different regions of the overlapped area (from anterior to posterior): 1) Anterior most margin; 2) Central region; 3) Posterior region, close to the contact with the exposed area. Note the increase in thickness of the vascular bone layer (spongiosa) and the lamellar bone layer (isopedine) from anterior to posterior and the changes in the bony ornamentation. Scale bar equals $500 \mu \mathrm{m}$. B. Bony ornamentations of the overlapped area from the anterior most margin (1) and the central region (2). Scale bar equals $100 \mu \mathrm{m}$. C. Horizontal cross section through the small bony tubercles of the overlapped area from the anterior most margin of a scale (1). Note the concentric patterns of ossification, the radial arrangement of osteocyte lacunae, and the openings of vascular canals between the tubercles. Scale bar equals $50 \mu \mathrm{m}$. Abbreviations: Ib, lamellar bone; vb, vascular bone. 

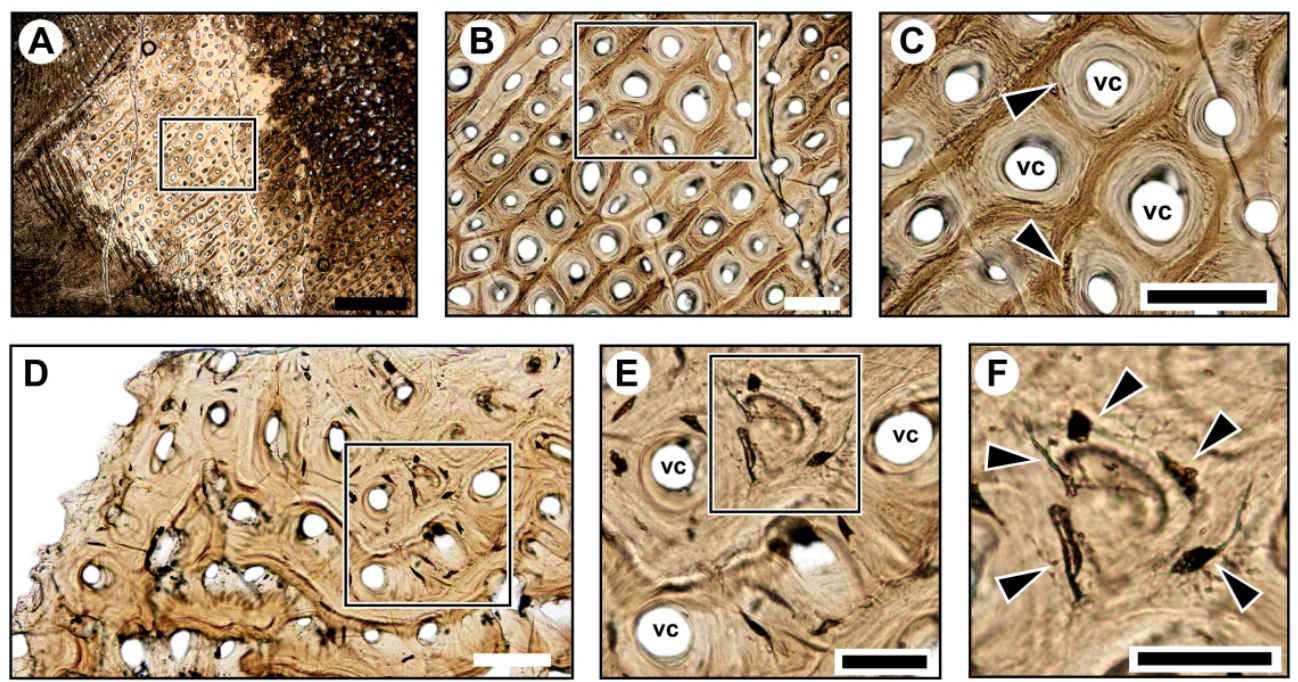

Microstructural and histological organization of the vascular bone of the scales of Miguashaia bureaui (horizontal cross sections of MHNM 06-1238). A. General view of the vascular bone layer (spongiosa) from the overlapped area of the scales. Note the uniform diameter and distribution of the vascular canals. Scale bar equals $500 \mu \mathrm{m}$. B. Detailed inset from A. Note that each vascular canal is surrounded by a series of concentric layers of woven-fibered bone (light brown) while each row of vascular canals is separated from the other by a denser bone tissue (dark brown). Scale bar equals $100 \mu \mathrm{m}$. C. Detailed inset from B. Arrow heads indicate the occurrence of osteocyte lacunae surrounding the vascular canals. Scale bar equals 50 $\mu \mathrm{m}$. D. General view of the vascular bone and vascular canals from another region of the overlapped area of a scale, probably from a more posterior region than in A. Note the more irregular distribution of the vascular canals and the occurrence of ossification waves. Scale bar equals $100 \mu \mathrm{m}$. E. Detailed inset from D. Note the occurrence of large osteocyte lacunae in the woven-fibered bone around the vascular canals. Scale bar equals $50 \mu \mathrm{m}$. F. Detailed inset from D. Arrow heads point to embedded osteocyte lacunae with large osteocytic prolongations. Scale bar equals $50 \mu \mathrm{m}$. 

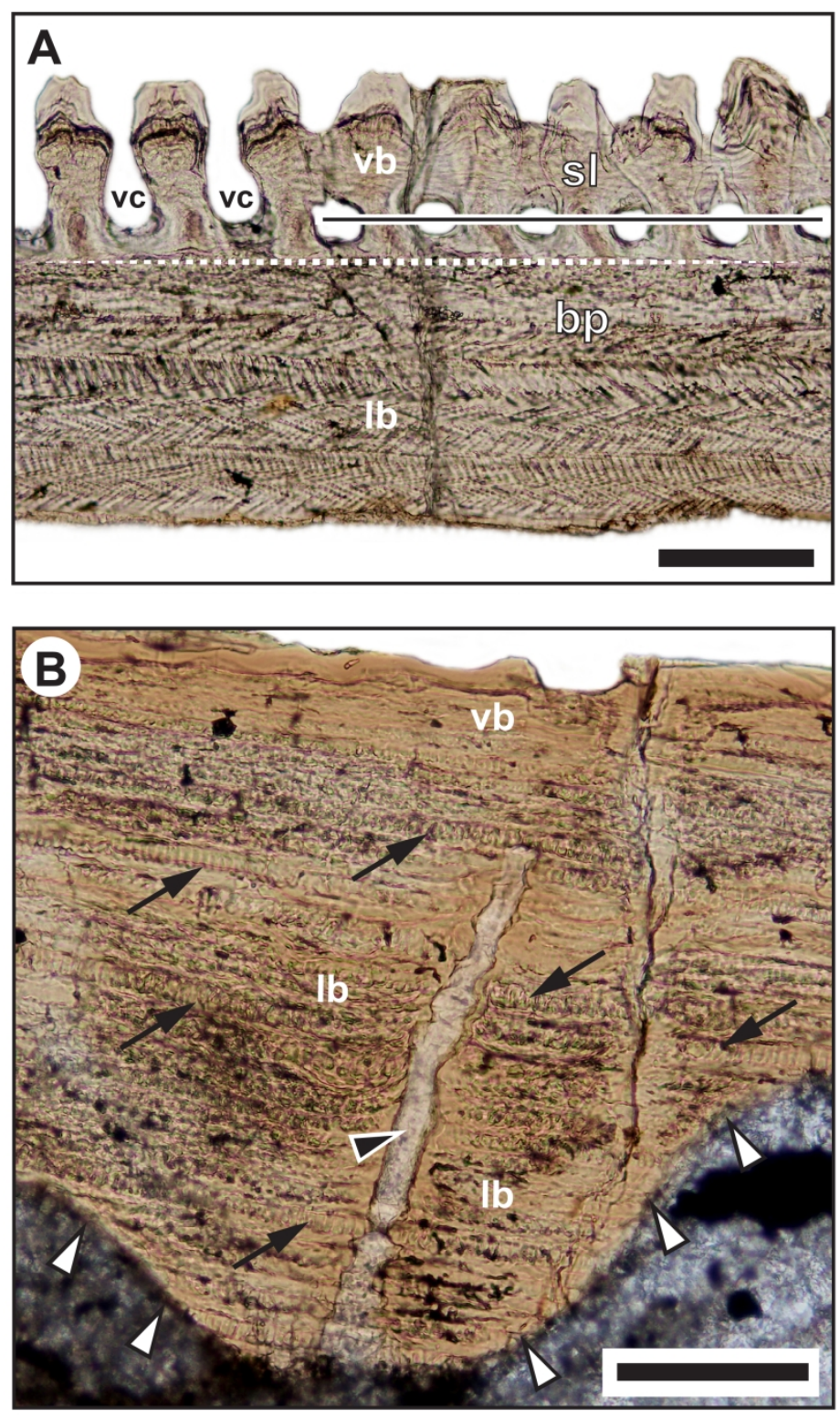

Microstructural and histological organization of the basal plate of the scales of Miguashaia bureaui (vertical cross sections of MHNM 06-1238 and MHNM 06-1495). A. General view of the vascular bone layer (spongiosa) of the superficial layer and lamellar bone (isopedine) of the basal plate from the anterior portion of the overlapped area of the scales (MHNM 06-1238). The horizontal plane corresponds to the approximative cross section plane in Fig. 6D-F. Note the clear differences in bone structure between the spongiosa (made of woven-fibered bone) and the isopedine (made of lamellar bone). Scale bar equals 100 $\mu \mathrm{m}$. B. Detailed view of the basal plate from the central portion of the exposed area of the scales (MHNM 06-1495). Black arrows indicate the repetitive pattern of collagenous plies with the same orientation. White arrow heads indicate the irregular front of mineralization of the visceral surface of the basal plate. The black

arrow head points to a vertical vascular canal piercing the basal plate and opening through the ventral surface of the scale. Note that the thickness of the basal plate is more important around the vascular canal resulting in a bump of the internal surface of the scale at this point. Scale bar equals $100 \mu$ m. Abbreviations: bp, basal plate; Ib, lamellar bone; sl, superficial layer; vb, vascular bone; vc, vascular canal. 

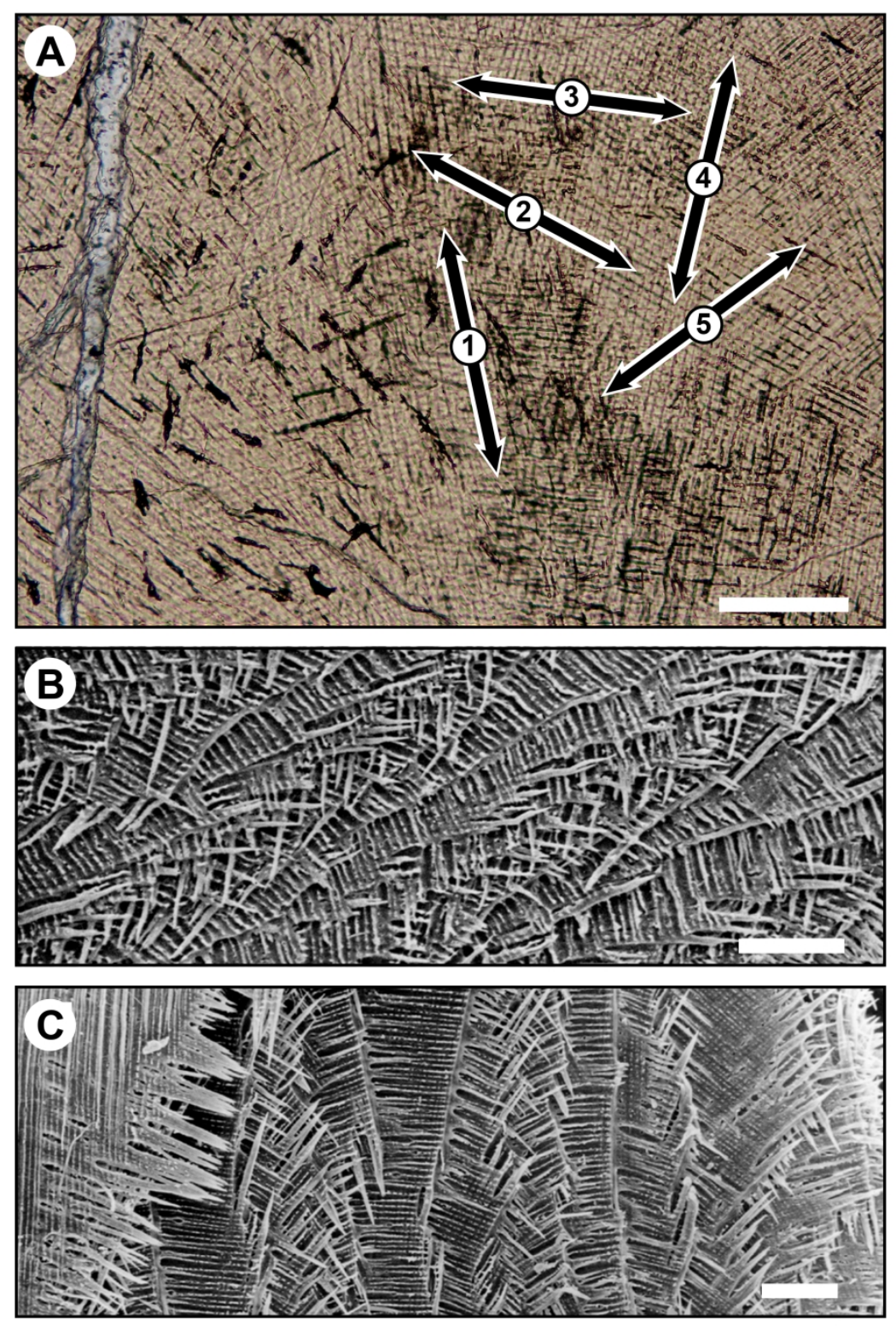

Basal plate comparison of the scales of Miguashaia and Latimeria in horizontal cross section. A. Miguashaia bureaui (MHNM 06-1238). Note the occurrence of 5 directions of the collagen fibers. B. Latimeria chalumnae (MNHN-ZA-AC-2012-29). C. Latimeria menadoensis (MZB 10003). Note the arciform pattern of the collagen plies evidencing a twisted-plywood arrangement of the layers of the isopedine. Scale bars equal $100 \mu \mathrm{m}$. 

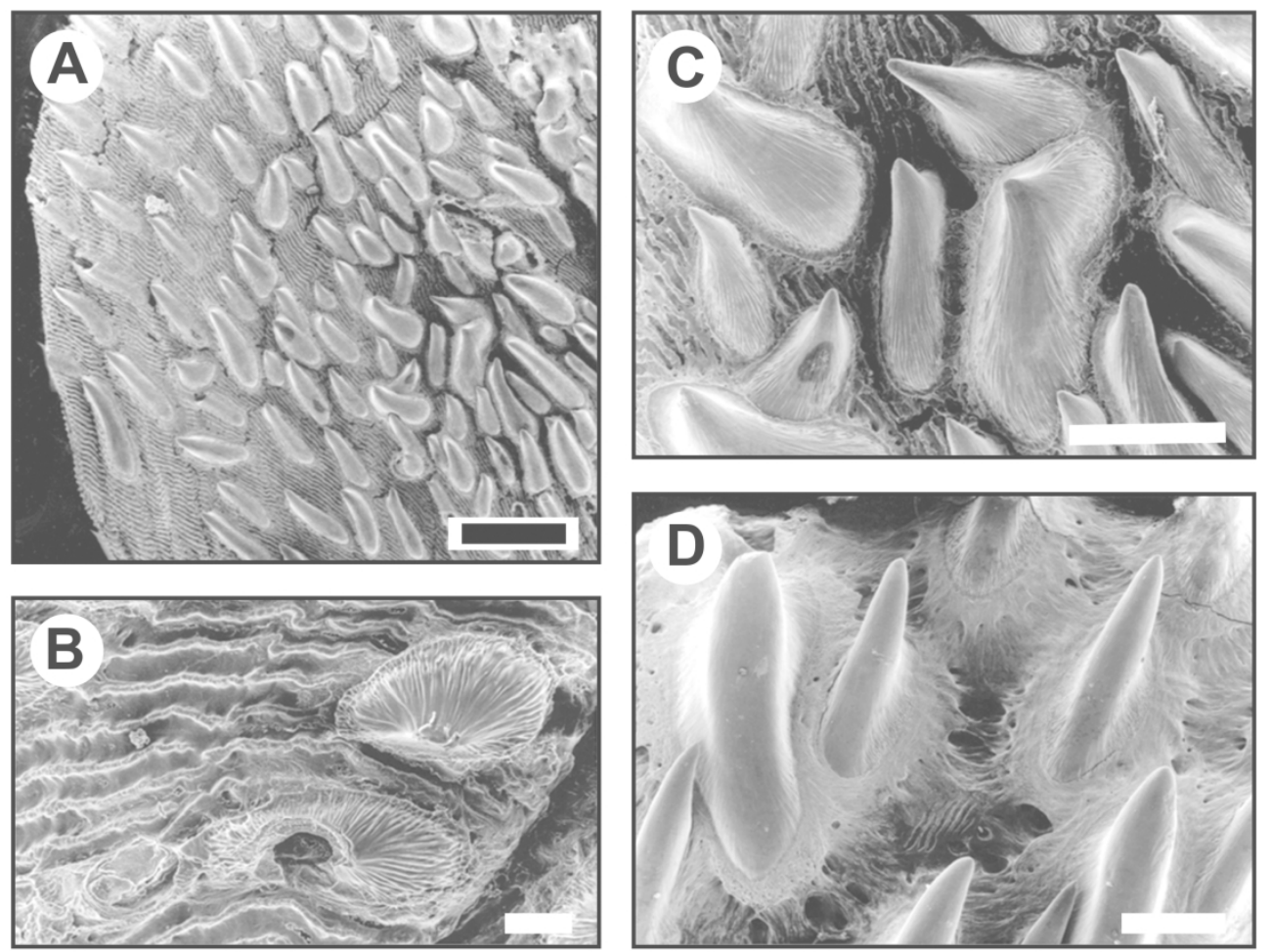

Odontodes from the exposed area of the scales of Latimeria (SEM). A. Latimeria menadoensis (MZB 10003). General view of the odontodes. The posterior margin of the scale is on the upper left of the image. The radial ridges of the superficial layer are clearly seen between the odontodes. Scale bar equals $500 \mu \mathrm{m}$. B-C. Latimeria menadoensis (MZB 10003). Detail of the odontodes and ridged surface of the superficial layer between the odontodes. Scale bar equals $100 \mu \mathrm{m}$. D. Latimeria chalumnae (MNHN 1989-806). Detail of the odontodes. The posterior margin of the scale is on the upper right of the image. Scale bar equals $100 \mu \mathrm{m}$. 


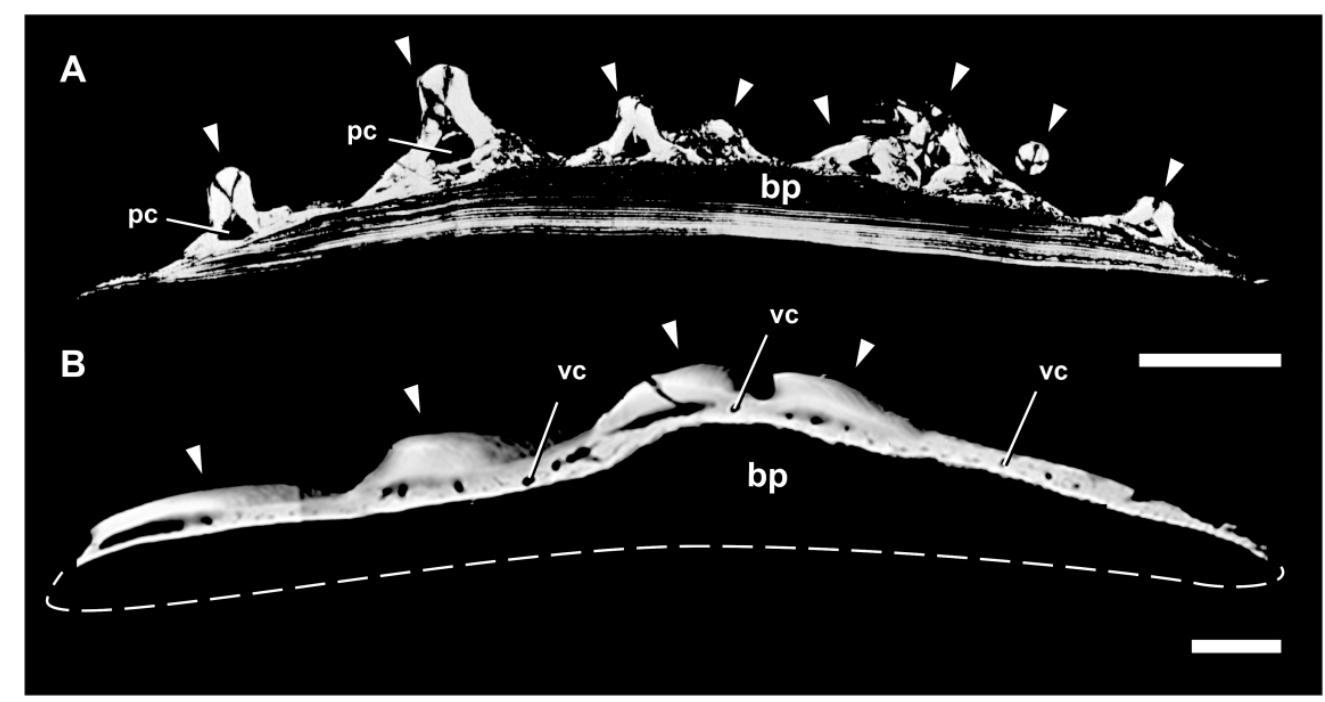

Ornamentation and microstructural organization of the scales of Latimeria. A. Latimeria chalumnae (MNHNZA-AC-2012-26). Transversal section of the exposed area of the scale in polarized light. The ornamented superficial layer displays eight odontodes (white arrow heads) with large pulp cavities and overlies the basal plate. Scale bar equals $1 \mathrm{~mm}$ (from Castanet et al. 1975). B. Latimeria menadoensis (MZB 10003). Longitudinal section of the exposed area in microradiography (anterior to the right). The ornamented superficial layer displays four odontodes (white arrowheads). Some vascular canals from the reduced spongiosa can be seen at the base of the odontodes. The whole basal plate is unmineralized and thus does not appear in the image, its approximative contour is represented with a white dashed line. Scale bar equals $1 \mathrm{~mm}$ (from Meunier et al. 2008). Abbreviations: bp, basal plate; pc, pulp cavity; vc, vascular canal. 


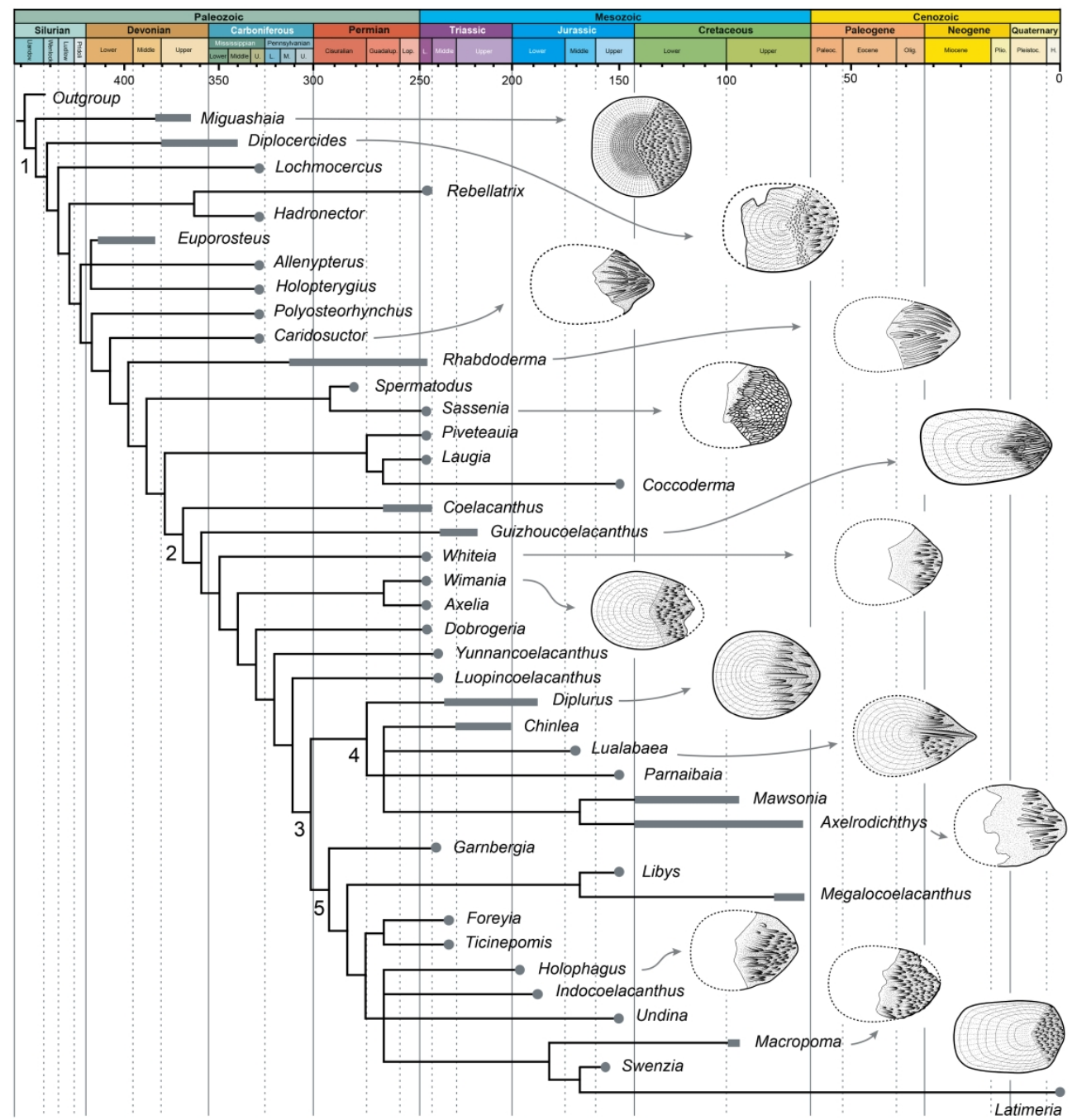

Evolution of scale morphology and ornamentation in coelacanths. Phylogenetic hypothesis after Cavin et al. 2017. The date of the diverging nodes is hypothetical. Original artwork of Miguashaia and Latimeria and modified drawings of Wimania after Stensiö 1921; Diplocercides after Stensiö 1937; Diplurus after Schaeffer 1952; Rhabdoderma, Sassenia, Whiteia, Lualabaea, Axelrodichthys, Holophagus, Macropoma after Forey 1998; Guizhoucoelacanthus after Geng et al. 2009. Nodes: 1. Actinistia; 2. Coelacanthiformes; 3. Latimerioidei; 4. Mawsoniidae; 5. Latimeriidae. Anterior of the scales to the left. 
A

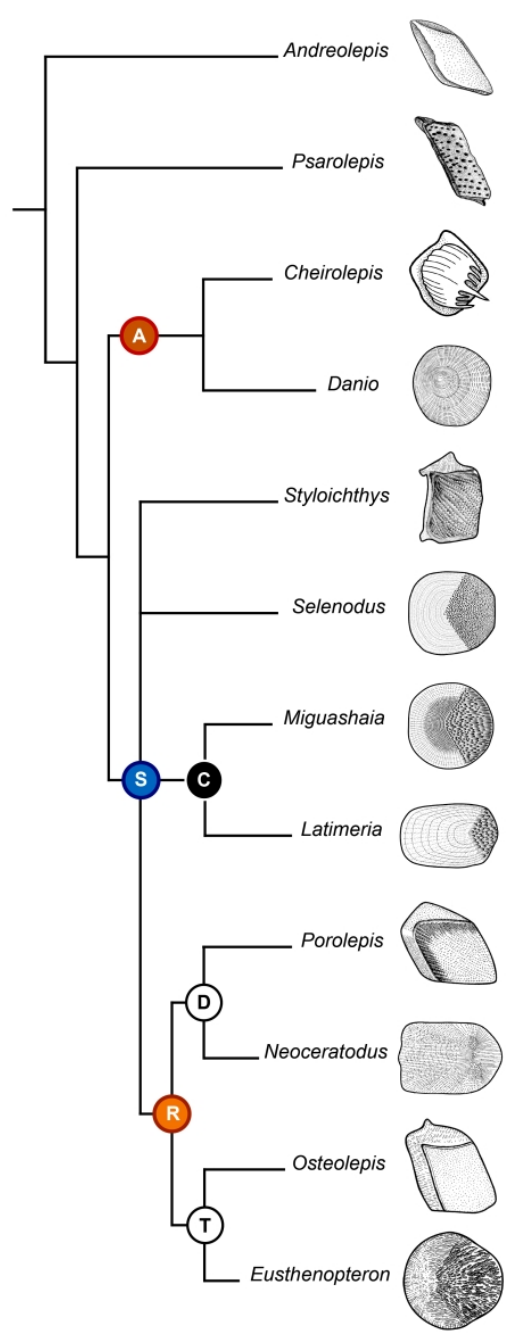

B

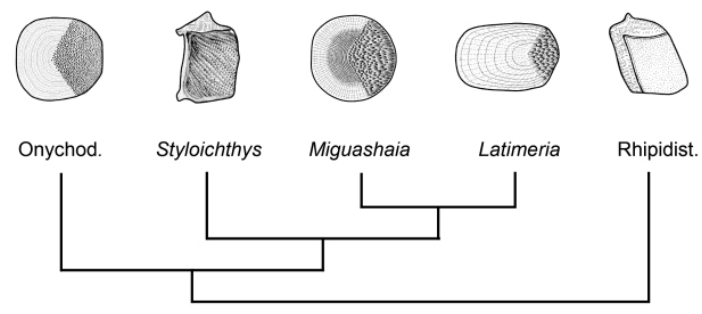

C
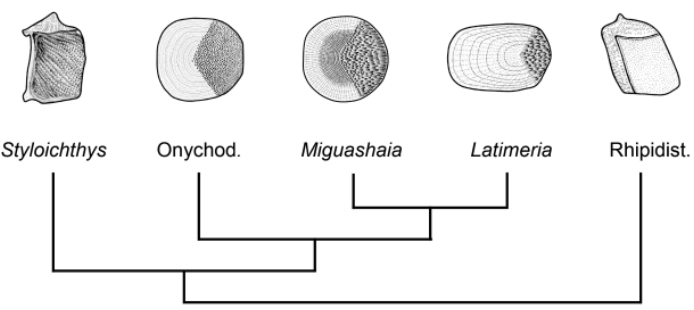

D
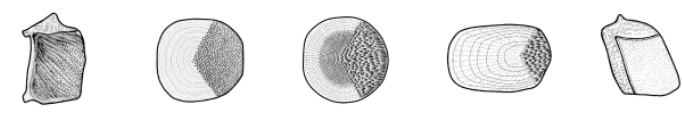

Onychod.

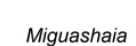

Latimeria

Rhipidist.
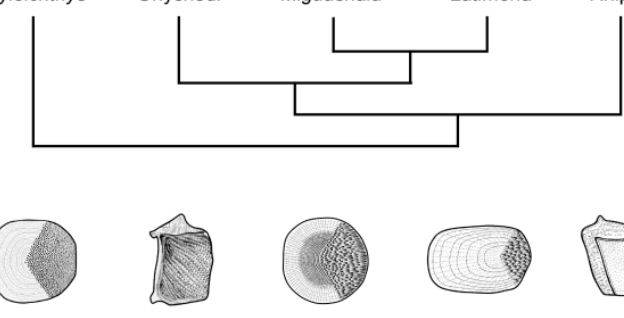

Onychod.

Styloichthys
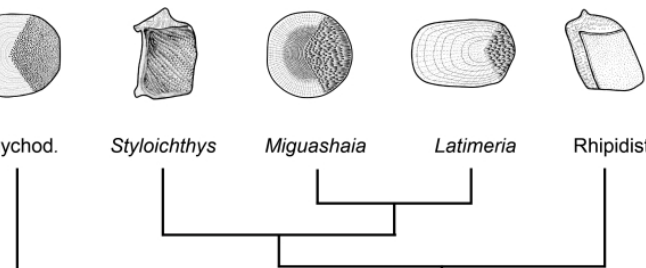

Phylogenetic hypothesis on early coelacanth evolution with special emphasis on the squamation. A.

Phylogenetic interrelationships of selected osteichthyans, highlighting the unresolved position of Styloichthys and onychodonts (represented here by Selenodus) relative to coelacanths (including here Miguashaia and Latimeria) (consensus of phylogenetic hypotheses after Friedman 2007; Lu et al. 2016a,b, 2017; MondéjarFernández 2020, among others). Abbreviations: A: actinopterygians, C: coelacanths D: dipnomorphs, R: rhipidistians, S: sarcopterygians, T: tetrapodomorphs. Original artwork of Miguashaia, Latimeria and Danio and modified drawings of Andreolepis after Gross 1968; Neoceratodus after Brien, 1962; Porolepis,

Osteolepis and Eusthenopteron after Jarvik, 1980; Cheirolepis after Pearson 1982; Styloichthys Lu \& Zhu 2008; Psarolepis after Qu et al. 2013; Selenodus after Mondéjar-Fernández 2020. Not to scale. B-E. Phylogenetic hypothesis of the possible interrelationships between Styloichthys, onychodonts (irrespective of their monophyly) and coelacanths. B. Onychodonts as stem coelacanths and Styloichthys as the sister group of coelacanths. C. Styloichthys as the sister group of the onychodont-coelacanth clade. D. Styloichthys as the sister group of the onychodont-coelacanth clade and rhipidistians. E. Onychodonts as the sister group of coelacanths (including Styloichthys) and rhipidistians. 


\section{A microanatomical and histological study of the scales of the Devonian sarcopterygian Miguashaia bureaui and the evolution of the squamation in coelacanths}

Jorge Mondéjar-Fernández (1)*, François J. Meunier (2), Richard

Cloutier (3), Gaël Clément (1) and Michel Laurin (1)

(1) UMR 7207 (MNHN-Sorbonne Université-CNRS), Centre de Recherche en Paléontologie - Paris, Département Origines \& Évolution, Muséum national d'Histoire naturelle, 57 rue Cuvier, CP38, Paris F-75005. [jorge.mondejarfernandez@mnhn.fr], [gael.clement@mnhn.fr], [michel.laurin@mnhn.fr]

(2) FRE BOREA 2030, (MNHN - Sorbonne Université - Univ. Caen Normandie - Univ. Antilles - CNRS - IRD), Département Adaptations du Vivant, Muséum national d'Histoire naturelle, CP26, 43 rue Cuvier, 75231 Paris cedex 05, France.

[francois.meunier@mnhn.fr]

(3) Université du Québec à Rimouski, 300 allée des Ursulines, Rimouski, Québec, G5L 3A1, Canada.

[richard_cloutier@uqar.ca]

\section{HIGHLIGHTS}

- The microstructure of the scales of the early coelacanth Miguashaia bureaui from the Devonian of Canada is revealed for the first time.

- The rounded scales display superimposed tubercles of dentine capped with enamel (odontodes) and a fully ossified basal plate.

- Miguashaia illustrates the primitive condition for coelacanths and reveals that the general histological arrangement of the coelacanth dermoskeleton has not significantly varied in the last 400 million years, contrary to the scale morphology and ornamentation, which has been more variable.

- Data on the squamation have important implications for the phylogenetic reconstruction of the evolutionary history of coelacanths. 